Historic, Archive Document

Do not assume content reflects current scientific knowledge, policies, or practices. 



\section{1 \\ SEED ANNUAL}

\section{VEGETABLES OF QUALITY}

The only way to get really good vegetables is to raise them in your own garden. You can perhaps buy vegetables as cheaply as you can raise them but it is usually impossible to buy them at their best. This is partly due to the fact that market growers often raise the varieties that look the best instead of those which taste the best. Another reason is that it is almost impossible to buy vegetables that are perfectly fresh. Such vegetables as sweet corn, snap or string beans, asparagus, peas, etc., deteriorate very rapidly after picking and by the time they are transported and sold they have lost many of their good qualities.

Raise your own! It may be more trouble to raise vegetables than to buy them but there is no comparison between sweet corn that is eaten within an hour or two after it is picked and the same corn kept for twenty-four or thirty-six hours as it usually has been when bought in the markets. Even if the fresh corn costs more to raise than the market price, it is well worth three times as much. The same is true of many other vegetables. It pays to raise them.

\section{FLOWERS}

Nothing adds so much to the attractiveness of a house and grounds as a few flowers well cared for, and nothing will give more satisfaction than watching them develop during the season. If the flower garden is well planned you can have a beautiful display from Spring until late in the Fall.

Even if very little land is available very pleasing results can be obtained especially if porch and window boxes are used to supplement the garden or border.

We are raising flower seeds and flowering plants on a large scale and can supply fresh seeds and freshly dug plants of the highest quality.

\section{Facts You Should Know Before Ordering}

\section{OUR SEEDS}

Are all fresh and reliable. Nothing is more essential to successful farming and gardening than good seed. With a full appreciation of this fact we offer only tried seeds of undoubted purity.

\section{SEEDS BY MAIL}

We send by mail, free of postage, Flower and Vegetable Seeds, excepting beans, corn and peas, on which postage must be added according to zone rates, which are very reasonable, seven cents for the first pound and one cent added for each additional pound in the first zone.

\section{BY EXPRESS}

At places where the express companies have offices, any of our goods can be ordered through their agents, who will furnish blanks for the purpose, saving postage and trouble. No charge whatever is made by the express companies for their services, other than the usual rate for carrying goods.

\section{HOW TO ORDER-REMITTANCES}

Orders should be accompanied with remittance or good reference. This saves much trouble and confusion during the hurrying season. The safest way is to send by registered letter, post-office order or express, except for sums of less than one dollar, for which we will accept stamps. Be particular to give name and post-office address full and distinctly.

NON-WARRANTY. There are contingencies continually arising to prevent the very best seeds always giving satisfaction. For these reasons, it is impossible to guarantee seeds under all circumstances; therefore we, The Harvey Seed Company, give no warranty, expressed or implied, as to description, quality, productiveness or any other matter of any seeds, bulbs, or plants we sell, and will not be in any way responsible for the crop. All our seeds are tested before sending them to our customers, and should they fail to grow if promptly and properly tested by the customer, will replace the same amount or give value in others. 


\section{VEGETABLE SEEDS}

You get the same high quality seed in these garden size packages as we furnish to the market gardener and florist, whose living depends upon the quality of seed he sows.

\section{ASPARAGUS-(German) Spargel}

Sow as early in the Spring as the ground will admit of working, in rows a foot apart. Keep carefully hoed and free from weeds, and the plants will be in condition to set out the succeeding Spring. The soil for the permanent beds should be thoroughly manured and trenched. Plant in rows three feet apart and one foot between the plants in the rows, and let the crown of the plant be covered about six inches deep. $1 \mathrm{oz}$. of seed will produce about 500 plants.

Palmetto. An early extra large variety. Oz. 10c, 1/4 1b. 25c, lb. 75c. Roots two years old, per dozen 30c, hundred $\$ 2.00$.

Giant Washington. Disease resistant variety and very vigorous. Pkt. 5c, oz. 15c, 1/4 lb. 50c, lb. $\$ 1.35$.

\section{BEANS FOR THE HOME GARDEN}

Beans require a light, rich soil. Plant two inches deep in drills two feet apart, and keep the earth about them loose and clean. Delay planting until the weather has become warm and settled, as they will not stand the least cold. 1 quart will plant about $100 \mathrm{ft}$. of row.

Hodson Wax. The most prolific bean in cultivation, with long, straight, beautiful yellow pods. For market gardeners it cannot be excelled, producing immense crops that sell themselves on sight. Pkt. 10c, $1 / 2$ lb. 15c, lb. 25c, 10 lbs. $\$ 2.00$.

Davis' Kidney Wax. The pods are long, straight, oval; clear waxy white color. Often growing to a length of 7 or 8 inches. Pkt. 10c, $1 / 2$ lb. 20c, lb. 30c, 10 lbs. $\$ 2.50$.

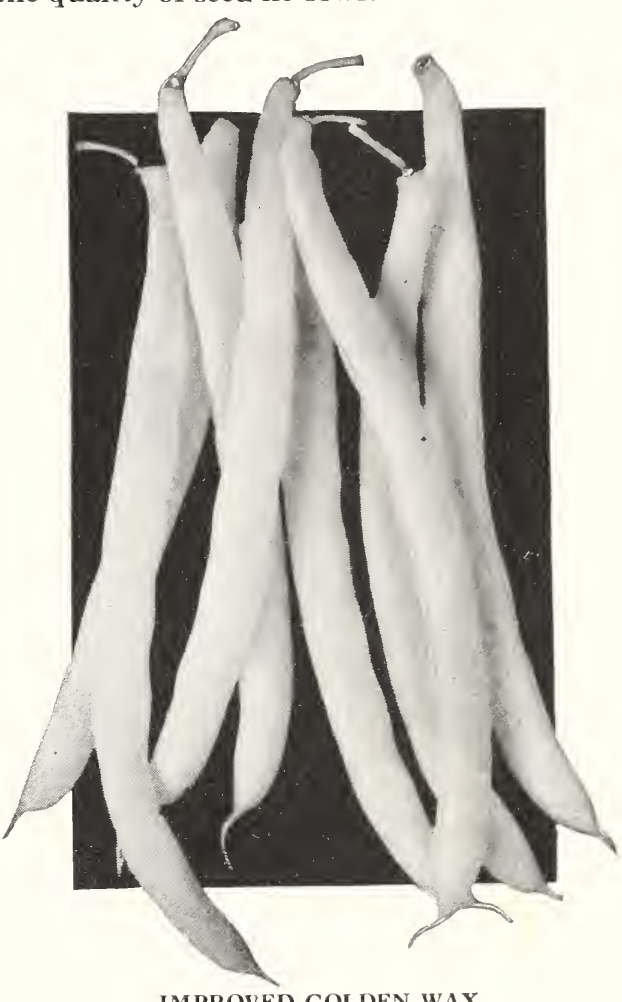

IMPROVED GOLDEN WAX
Pencil Pod Black Wax. Pods round, transparent and yellow. Tender and delicate in flavor. Pkt. 10c, $1 / 2$ lb, 20c, lb. 30c, 10 lbs. $\$ 2.50$.

Improved Golden Wax. An old and well-known variety. Round pods. Pkt. 10c, 1/2 1b. 20c, 1b. 30c, 10 lbs. $\$ 2.50$.

Round Pod Kidney Wax or Brittle Wax. Possesses all the excellent qualities of the well-known Wardwell's Kidney Wax, with the advantage of a round pod, which is entirely stringless. Large size and very early. Valuable for market. Pkt. 10c, 1/2 lb. 20c, 1b. 30c, 10 lbs. $\$ 2.50$.

Wardwell's Kidney Wax. Pods long, broad, flat, and of good quality. Very popular. Pkt. 10c, 1/2 lb. 20c, lb. 30c, 10 lbs. $\$ 2.50$.

Scarlet Runners. Pkt. 10c, Lb. 50c.

Bags Extra on Beans, Peas, Grass Seed And Seed Grains

\section{POLE OR RUNNING BEANS}

Set the poles 3 by 4 feet apart and plant 5 or 6 beans around each pole. They are not so hardy as the dwarf varieties, and should not be planted till the weather is settled and warm. They need the best of soil to do well. 1 quart to 150 poles.

Kentucky Wonder. Long, round, slender green pods, very prolific. Pkt. 10c, $1 / 2$ lb. 20c, 1b. 30c, 10 lbs. $\$ 2.50$.

\section{Lima Beans}

King of the Garden. Pkt. 10c, 1/2 lb. 25c, 1b. 40c, 10 lbs. $\$ 3.75$.
Leviathan. A week earlier than any other variety. Strong grower, takes to the poles more readily than others, producing its pods in clusters, well filled with large, fleshy beans. Pkt. 10c, 1/2 lb. 25c, lb. 40c, 10 lbs. $\$ 3.75$.

\section{Green Podded Beans}

Black Valentine. Very early, green pods. Pkt. 10c, $1 / 2$ lb. 20c, lb. 30c, 10 lbs. $\$ 2.50$.

Bountiful. A variety of recent introduction and its many good qualities should bring it into general use. Upright in growth, vigorous and productive, pods long, of most excellent flavor and entirely stringless until nearly ripened. Should be in every garden. Pkt. 10c, 1/2 lb. 20c, 1b. 30c, 10 lbs. $\$ 2.50$.

Burpee's Stringless. The finest green-podded variety extant, entirely stringless. Pkt. 10c, $1 / 2$ lb. 20c, lb. 30c, 10 lbs. $\$ 2.75$.

Refugee Stringless Green Pod. Ask for price.

Refugee, or Thousand to One. The well-known pickling and canning variety. Pkt. 10c, 1/2 lb. 20c, lb. $30 \mathrm{c}, 10$ lbs. $\$ 2.25$.

White Kidney, or Royal Dwarf. Used extensively as a shell bean; none better. Lb. 20c, 10 lbs. $\$ 1.85$.

White Marrowfat. Lb. 20c, 10 lbs. $\$ 1.85$.

\section{Bush Limas}

Burpee's Bush Lima. A bush form of the large pole Lima. The bushes grow from eighteen to twenty inches high, of stout growth and always erect, yet branching vigorously; and hence, a good bearer. Pkt. 10c, 1/2 lb. 25c, lb. 40c, 10 lbs. $\$ 3.75$.

Bags Extra on Beans, Peas, Grass Seed And Seed Grains 


\section{Harvey's Table Beets}

Select rich, sandy loam, and sow in drills 16 inches apart, and cover an inch deep. When the young plants appear, thin to 4 inches apart, and keep the ground well worked. For early use sow as soon as the ground can be worked in the Spring, and for general crop, about the middle of May. The Mangel Wurzels are grown solely for stock, and require about the same treatment as the beets. $1 \mathrm{oz}$. of seed will plant 50 feet of row.

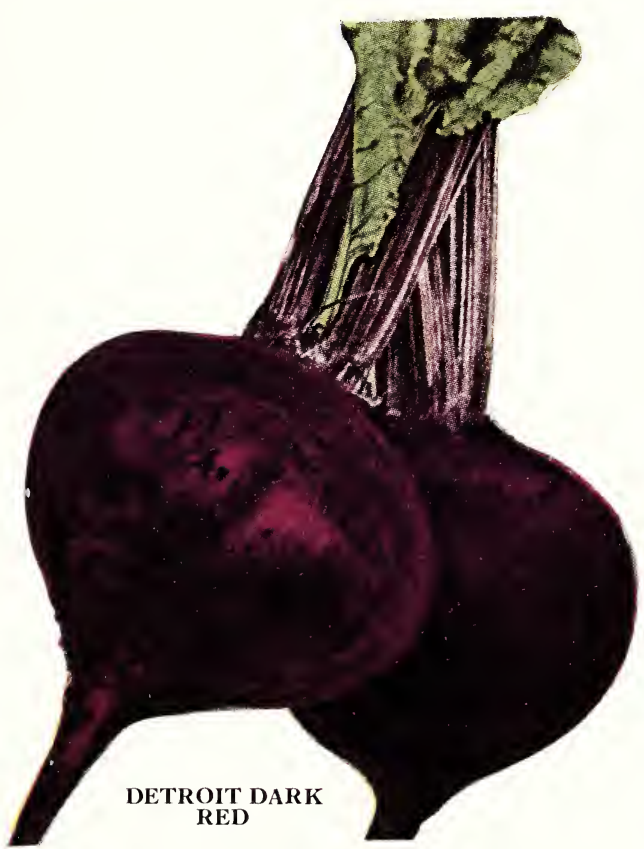

BROCCOLI-(German) Spargel Kohl

The Broccoli are so closely allied to the Cauliflower as to be scarcely distinguishable either by taste or color. They are more hardy and certain to head; they require the same treatment. One ounce of seed will produce about 2,500 plants.

Italian Green Sprouting. Pkt. 15c, oz. $\$ 1.00,1 / 4 \mathrm{lb}$. $\$ 3.00$.

\section{BORECOLE OR KALE- \\ (German) Blatter Kohl}

Sow from middle of April to May; in June transplant to rich, mellow soil, and cultivate same as Cabbage. They are rendered very tender and delicious by moderate touches of frost in Autumn.

Green Curled Scotch. Bright green, beautifully curled. Pkt. 5c, oz. 15c, 1/4 lb. 40c, lb. \$1.25.

Tall Curled. Very hardy and prolific. Pkt. 5c, oz. $15 \mathrm{c}, 1 / 4$ lb. 40c, lb. $\$ 1.25$.

\section{THE KITCHEN GARDEN COLLECTION}

1 pkg. Beans, Pencil Pod 1 pkg. Cabbage, Chinese

1 pkg. Beet, Detroit 1 pkg. Lettuce, Prizehead

1 pkg. Carrot, Nantes 1 pkg. Peas, Little Gem

1 pkg. Cucumber, Fortune 1 pkg. Peas, Laxtonian

1 pkg. Beans, Burpee's Stringless Green Pod

1 pkg. Parsley, Moss Curled

1 pkg. Radish, Scarlet Globe

1 pkg. Turnip, White Globe

12 Splendid Varieties for 70c

Arlington Blood Turnip. One of the best all-around Beets. Dark red in color and of good form. Pkt. 5c, oz. 15c, $1 / 4 \mathrm{lb}$. 40c, lb. \$1.25.

Eclipse. Noted for its rapid growth and extreme smallness of top. Pkt. 5c, oz. 10c, 1/4 lb. 30c, lb. 90c.

Crosby's Egyptian. Dark, blood red, an old favorite. Pkt. 5c, oz. 10c, 1/4 lb. 30c, lb. 90c.

Detroit Dark Red. A fine shaped variety, largely used by the canners. Pkt. 5c, oz. 10c, 1/4 lb. 35c, lb. $\$ 1.00$.

Early Wonder. A very good early beet resembling the Crosby's Egyptian but more flattened than a good strain of that variety and is a few days earlier. The beets are dark red and have small tops. Pkt. 5c, oz. 15c, 1/4 lb. 40c, lb. $\$ 1.50$.

Swiss Chard or Spinach Beet. Cultivated for its leaf stocks, which are served as asparagus, and for its leaves cooked as spinach; cut often, new and more tender stalks will be produced. Pkt. 5c, oz. 15c, 1/4 lb. 30c, lb. 95c.

Special Price on Quantities

\section{Mangel Wurzels}

Mammoth Long Red. Of immense size, tends less to hollow necks than the common long red varieties. Oz. 10c, 1/4 lb. 25c, 1b. 50c.

Golden Tankard. Flesh deep yellow, with light colored rings; good cropper. Oz. 10c, $1 / 4$ lb. 20c, lb. 50c.

Giant Half Sugar. Oz. 10c, 1/4 lb. 20c, lb. 50c.

\section{BRUSSELS SPROUTS-}

(German) Kopf Kohl

Allied to the Cabbage family, producing from the stalks of the plants an abundance of sprouts resembling small Cabbages. Cultivate same as Cabbage.

Dwarf Improved. Very fine heads. Pkt. 5c, oz. 25c, $1 / 4$ lb. $75 c$, lb. $\$ 2.50$.

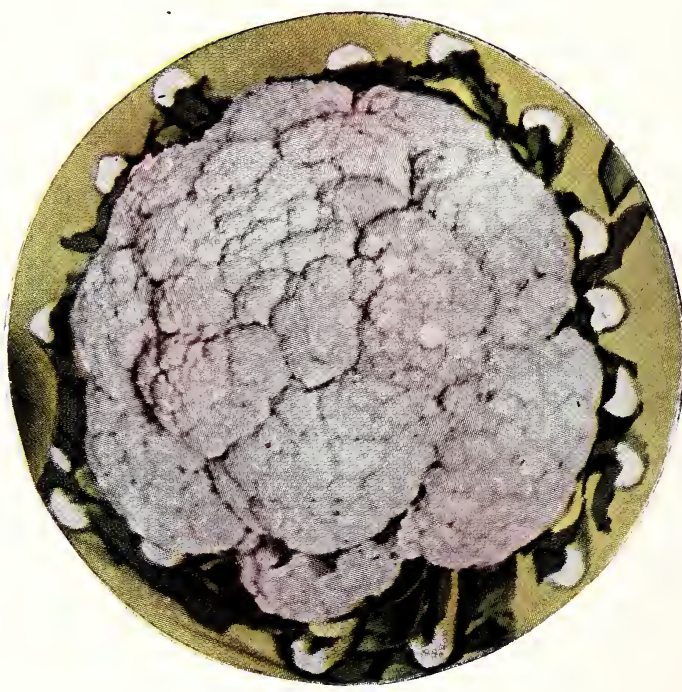

EARLY SNOWBALL 


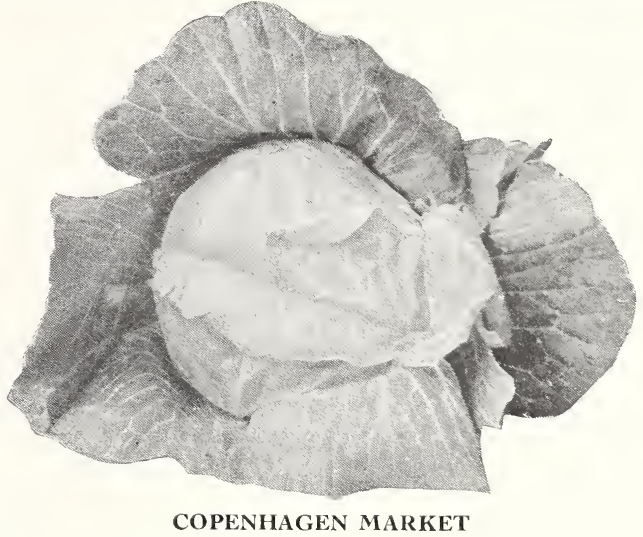

\section{Harvey's Cabbage}

\section{CABBAGE-(German) Kopf Kohl}

Sow the seeds of the early varieties in hotbeds the latter end of February or early in March, and transplant in April. For second early sow the seed in open ground early in May, and for late use, the first of June. In planting, set the stem well down. The ground should be frequently worked to get good results. $1 \mathrm{oz}$. of seed will produce about 2,000 plants.

Early Jersey Wakefield. A standard early cabbage in Boston markets. Pkt. 5c, oz. 25c, 1/4 lb. 75c, lb. $\$ 2.00$.

Henderson's Early Summer. The earliest of the drumhead varieties. Pkt. 5c, oz. 30c, 1/4 lb. \$1.00, lb. $\$ 3.00$.

Early Winningstadt. Undoubtedly the best coneshaped Cabbage in existence, extremely hard. Pkt. 5c, oz. $25 \mathrm{c}, 1 / 4$ lb. $75 \mathrm{c}, 1 \mathrm{~b}$. $\$ 2.00$.

Short Stem Danish. A little earlier than the Danish Ball Head, with shorter stem, always hard, uniform in size and heavy. Pkt. 10c, oz. 50c, 1/4 lb. 90c, lb. $\$ 2.80$.

All Seasons. A type of the old premium Flat Dutch. May be planted earlier. Pkt. 5c, oz. 25c, 1/4 lb. $75 \mathrm{c}, \mathrm{lb}$. $\$ 2.00$.

Golden Acre. Very early flat head cabbage. The best early cabbage. Pkt. 15c, oz. 50c, 1/4 lb. $\$ 1.50$, lb. $\$ 4.00$.

Copenhagen Market. Extra early. Large, round heads. Pkt. 10c, oz. 30c, 1/4 lb. 90c, lb. $\$ 3.00$.

Glory of Enkhuizen. A new round early variety from Holland, early as Wakefield, with shape of Danish Ball Head, never cracks in the field and for early market is unsurpassed. Pkt. 10c, oz. 25c, 1/4 lb. 75c, lb. $\$ 2.60$.

Large Late Drumhead. A superior Fall and Winter variety. Pkt. 5c, oz. 30c, 1/4 lb. 75 c. lb. $\$ 2.75$.

Premium Flat Dutch. Too well known for comment, a sure header. Pkt. 5c, oz. 25c, 1/4 lb. 75c, lb. \$2.00.

Red Drumhead. Used for pickling. Pkt. 10c, oz. $35 \mathrm{c}, 1 / 4$ lb. $\$ 1.00,1 \mathrm{lb} . \$ 3.00$.

Improved Drumhead Savoy. Larger than Ulm, not quite so early. Pkt. 5c, oz. 25c, 1/4 lb. 75c, 1b. $\$ 2.75$.

\section{CAULIFLOWER - (German) Blumen Kohl}

It requires much the same treatment as the Cabbage and reaches perfection in the cool, moist weather of the Fall months.

Dry Weather. Large white solid heads with large leaves, which protect it from the weather, about 10 days later than the Erfurt, a splendid sort for the main crop. Pkt. 25c, oz. $\$ 2.00,1 / 4$ lb. $\$ 7.50$.

Dwarf Erfurt. "Seed specially selected." Easily deserves first place in the list. Our stock of this variety is perfect. It is a beautiful white curd, and will head under the most adverse circumstances. Pkt. 15c, oz. $\$ 1.50,1 / 4$ lb. $\$ 5.25$.

Early Snowball. Extensively grown; always making a good crop under favorable conditions; valuable both for early and late crops. Pkt. 25c, oz. $\$ 1.50$, $1 / 4$ lb. $\$ 5.25$.

\section{CHINESE or CELER Y CABBAGE}

Cut into quarters and boiled with a meat or alone, its mild, rich flavor and tenderness put it far ahead of Cabbage. Sliced thinly and served cold with a cream dressing, it makes a most appetizing cold slaw. Served with broiled sliced bacon and a hot meat gravy poured over it, it is very good. Boiled, fried, baked with cheese, any way you have a mind to cook or serve Chinese Cabbage, you will find it delicious. There won't be any tough outside leaves to it, for it's practically all heart, tender, crisp and juicy. It's very easily grown. Sow the seed in July in rows 15 inches apart and thin the same as Lettuce. A wonderful new salad plant, very rapid grower. Pkt. 5c, oz. 30c, 1/4 lb. $\$ 1.00$, lb. $\$ 3.50$.

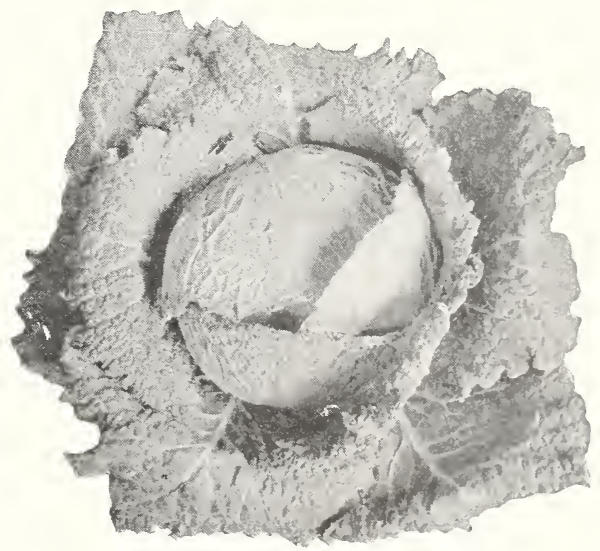

IMPROVED DRUMHEAD SAVOY

TREAT your Cabbage, Cauliflower, Pepper and in general all seeds started under glass, before planting with SEMESAN. This generally prevents and controls damping off, increases germination and produces a more robust plant in less time. See page 30 . 


\section{Carrots for Garden and Farm \\ CARROTS-(German) Mohre}

Carrots require a rich, sandy soil to reach perfection. For an early supply sow in the Spring as soon as the ground can be worked. Carrots are very susceptible to dry weather which is apt to prevent the germination of the seed or burn the young plants as soon as they appear above the ground. It is therefore advisable to use a liberal quantity of seed, which will give the crop a better chance. One ounce of seed will plant 150 feet of drill.

Guerande or Oxheart. This variety, while not attaining one-half the length of some other varieties, will compare favorably in bulk of crop with any. What it lacks in length is made up in thickness. The crop can easily be pulled, no digging being required. Pkt. 5c, oz. 15c, 1/4 lb. 35c, lb. $\$ 1.00$.

Danvers. A cross between the Short Horn and Long Orange, the most popular general crop variety. Pkt. 5c, oz. 15c, $1 / 4$ lb. 35c, lb. $\$ 1.10$.

Chantenay. A stump-rooted, scarlet variety. Roots broad shouldered and always symmetrical. Try it for market; it will please you. Pkt. 5c, oz. 15c, 1/4 lb. 35c, lb. \$1.10.

Improved Long Orange. The most popular of the older varieties. Oz. 10c, $1 / 4$ lb. 35c, lb. $\$ 1.00$.

Coreless. A very fine variety for table use. The carrots are very tender, of mild pleasant flavor, and without any hard core as in some varieties. The shape is ideal for a table carrot, being practically the same size from crown to bottom. The roots grow to a medium size, are very smooth and of a deep orange-red color all through. The carrots grow rapidly and are excellent for use when either young or full grown. Pkt. 5c, oz. 15c, $1 / 4$ lb. 35c, lb. $\$ 1.20$.

White Belgian. The largest variety, grown exclusively for stock; grows one-third out of the ground. $1 / 4 \mathrm{lb} .35 \mathrm{c}, \mathrm{lb}$. $\$ 1.00$.

SPECIAL PRICE ON QUANTITIES

\section{Celery}

\section{CELERY-(German) Seleri}

Plant seed in hotbed, or very early in open ground. When three inches high, transplant four inches apart, water and protect until well rooted, then transplant to trenches, setting the plants twelve inches apart in rows. To blanch, draw the earth around the plants from time to time, taking care not to cover the tops of the center shoots.

Golden Self Blanching. The leading early market variety, of dwarf habit, and of a beautiful golden yellow color. We have the right stock of this variety. Pkt. 10c, oz. 40c, $1 / 4$ lb. $\$ 1.75$.

Winter Queen. Most popular of all for Winter use, has large heart of rich golden yellow, and good keeper. Pkt. 5c, oz. 30 c, $1 / 4$ lb. 80 c, lb. $\$ 2.50$.

Giant Pascal. An easily blanched and fine keeping sort; stocks very wide and thick; a good late variety. Pkt. 5c, oz. 25 c, $1 / 4$ lb. $75 c$, lb. $\$ 2.50$.

Columbia. Good general crop variety. Pkt. 10c, oz. 60c, $1 / 4$ lb. $\$ 1.75$, lb. $\$ 6.00$.

White Plume. A distinct variety of great merit. Its stalks and inner leaves are naturally white, so that by tying up with matting or drawing the earth up around the plants with the hands, the work of blanching is completed. Pkt. $5 c, 0 z .25 c, 1 / 4$ lb. $75 c, 1 b . \$ 2.50$.

Sanford Superb, or Easy Bleacher. This is one of the most valuable varieties that has come to our notice. Plants set out the same time as Golden Self-Blanching will be ready for market two weeks later. Bleaches readily with boards and grows well both on muck and upland. It is equally as stout and a trifle taller than Golden Self-Blanching, and is less liable to blight. The eating and keeping qualities are both far superior to Golden Self-Blanching. Pkt. 15c, oz. 50c, $1 / 4$ lb. $\$ 2.00,1 b . \$ 6.00$.

Celeriac, or Turnip Rooted. Roots largely used for soups. Pkg. 5c, Oz. 30c, $1 / 4$ lb. $\$ 1.00$, lb. $\$ 3.00$.

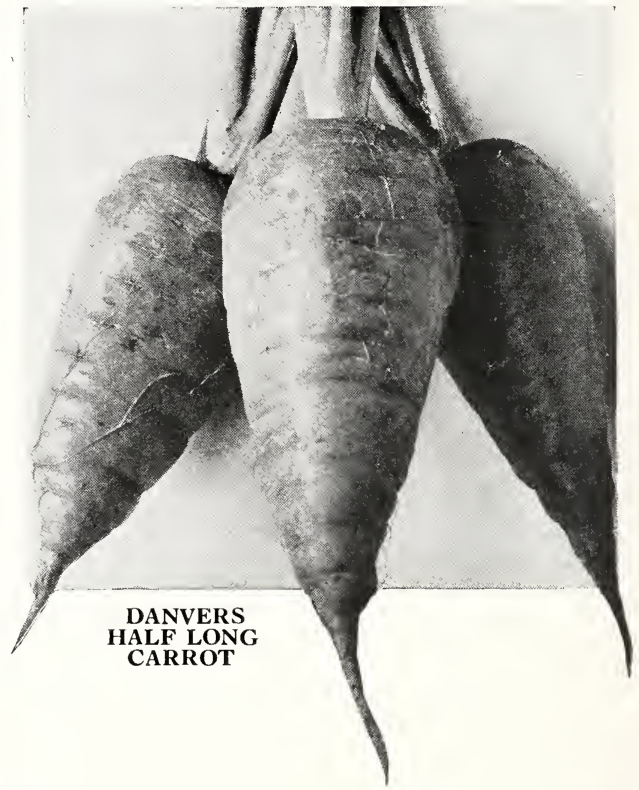

Better Crops from Harvey's Seeds.

A Standard of Quality for City, Farm and Suburban Homes.

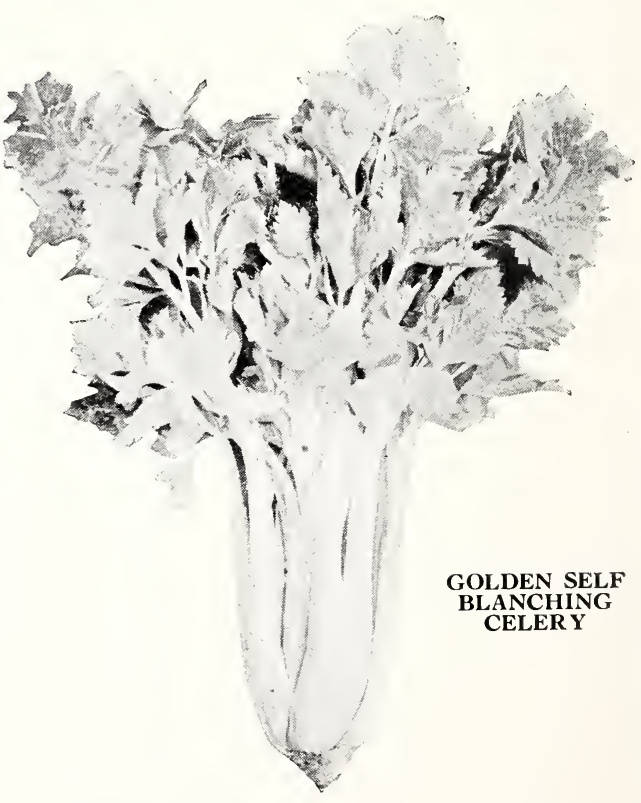




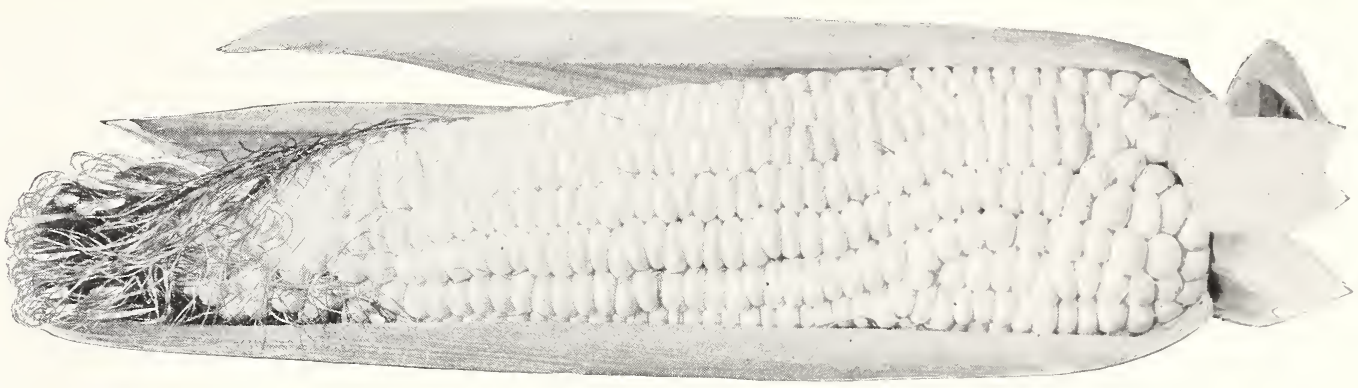

GOLDEN BANTAM

\section{Corn \\ CORN-(German) Corn}

Plant the smaller varieties about the middle of May, in drills three feet apart, stalks ten inches apart in the rows, or in hills three feet apart each way. The taller varieties on rich soil should be given more space. We have taken great pains to secure only the best varieties. One quart will plant 200 hills.

Harvey's Early. A magnificent early variety, bearing ears as large as Evergreen, and earlier than any other corn grown, excepting the Dwarf Corys, and almost invariably carry two good ears. For market gardeners it is unexcelled. Pkt. 10c, lb. 30c, 10 lbs. \$2.00.

White Cory. Equally as early as the Red Cory, with the advantage of being pure white. Pkt. 10c, lb. 30 c, 10 lbs. $\$ 2.00$

Crosby's Early Sweet. A rather small-eared variety, excellent for private gardens. Pkt. 10c, lb. 30c, 10 lbs. $\$ 2.00$.

Black Mexican. A black grained variety; one of the sweetest; excellent for private gardens. Pkt. 10c, lb. $40 \mathrm{c}, 10 \mathrm{lbs}$. $\$ 2.25$.

Bantam Evergreen. An early or intermediate, yellow grained sweet corn of distinctive merit. Ears about seven inches long, usually twelve rowed and when in condition for use are light creamy yellow in color. The grain is rather short, very sweet and tender and is unsurpassed in quality. In season it is a few days later than Golden Bantam, but remains in condition much longer than that variety. An excellent sort both for the home and the market garden. Pkt. 10c, lb. 30c, 2 lbs. 60c, 10 lbs. $\$ 2.00$.

Country Gentleman. Next to the Black Mexican, the sweetest sort grown. Grains grow in irregular rows. Pkt. $10 \mathrm{c}, 1 \mathrm{lb} .45 \mathrm{c} ; 10$ lbs. $\$ 3.00$.

Early Minnesota. A good early sort. Ears short, but firm. Pkt. 10c, 1b. 30c, 10 lbs. $\$ 2.00$.

Stowell's Evergreen. A well-known, late variety. Remains green longer than any other kind. Pkt. 10c, lb. $40 \mathrm{c}, 10 \mathrm{lbs}$. $\$ 3.00$.

Golden Bantam. The earliest and sweetest of all sweet corn, stock grows from $3 \frac{1}{2}$ to $4 \mathrm{ft}$. high and bears from two to three ears 5 or 6 inches long, with eight rows of bright yellow grains, which are of the most delicious and tender quality. Though one of the earliest, it may be had throughout the season by successive plantings. Pkt. 10c, lb. 30c, 10 lbs. \$2.00.

Pop Corn (White Rice). An old and popular variety. lb. $25 \mathrm{c}$.

Jap Hulless. 1b. 25c.

\section{CORN SALAD, OR FETTICUS}

(German) Lammersalat

A nice salad; is fit for use in six or eight weeks from time of sowing. If wanted early in Spring, sow in September and cover with straw or leaves as soon as cold weather sets in.

Large Seeded. Pkt. 5c, oz. 15c, 1/4 lb. 40c, lb. $\$ 1.25$.

\section{Cucumbers for the Home Garden \\ CUCUMBER-(German) Ghurke}

Cucumbers should not be planted until all danger from frost is past. Sow in light, rich soil, in hills four feet apart, the seeds to be covered about one-half inch with finely pulverized soil and firmly pressed down with the back of the hoe. When well up and out of danger from insects, thin to four plants in a hill. The middle of June is early enough to plant for pickling. $1 \mathrm{oz}$. will plant 50 hills.

Early Fortune. One of the best. Fruits average nine inches long. Early and very productive. Pkt. 5c, oz. $15 \mathrm{c}, 1 / 4$ lb. $40 \mathrm{c}, 1 \mathrm{~b} . \$ 1.25$.

Early Frame. A very popular variety, short and prolific. Pkt. 5c, oz. 10c, 1/4 lb. 30c, lb. \$1.00.

Boston Pickling. Medium size, superior quality. Pkt. 5c, oz. 10c, 1/4 lb. 30c, lb. $\$ 1.00$.

Klondike. An extra fine white spine type. Pkt. 5c, oz. 15c, $1 / 4$ lb. 40c, 1b. $\$ 1.15$.

White Spine. Excellent for table use; a great bearer. Pkt. 5c, oz. 15c, 1/4 lb. 40c, lb. \$1.15.

Improved Long Green. An old standard sort; makes hard, brittle pickles. Pkt. 5c, oz. 15c, 1/4 lb. 40c, lb. $\$ 1.25$.

Green Prolific. As a pickling variety is unsurpassed. Noted for its uniform growth and great productiveness. Pkt. 5c, oz. 15c, 1/4 lb. 40c, 1b. $\$ 1.10$.

Fordhook. Perfectly smooth, dark green, handsome fruits, 12 inches long. Pkt. 5c, oz. 15c, 1/4 lb. 40c, lb. $\$ 1.25$.

The Davis Perfect. In color a dark glossy green Shape, slim and symmetrical, with an average length of ten to twelve inches. They never grow pussy and hold their color till nearly ripe. The quality is fine, as it has very few seeds, which are small and very soft when fit for table use. It is a strong grower and successfully resists the cucumber disease. Pkt. 5c, oz. $15 \mathrm{c}, 1 / 4$ lb. $40 \mathrm{c}, 1 \mathrm{~b} . \$ 1.25$. 


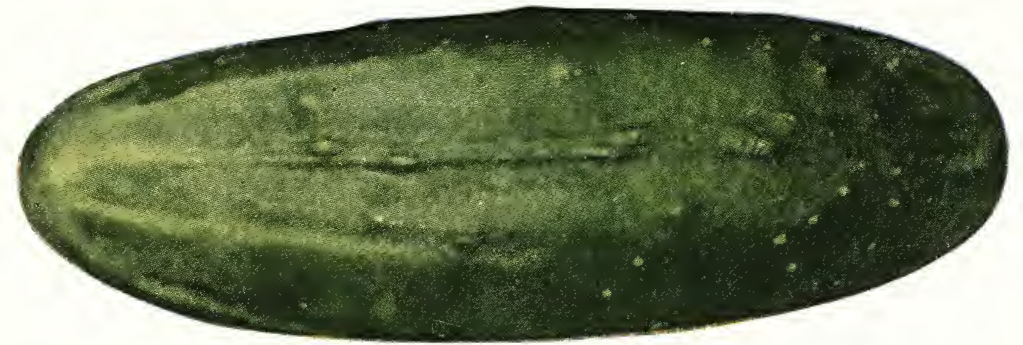

EARL Y FORTUNE
CUCUMBER - Continued

Extra Long WhiteSpine. Longer than the Improved White Spine, a very handsome variety. Pkt. 5c, oz. 15c, 1/4 lb. 40c, lb. $\$ 1.25$.

Woodruff's Hybrid. A popular Cucumber for market. Grow's 8 to 10 inches long, deep green and stays green a long time. It is a white spine variety. Pkt. $10 c$, oz. $15 c, 1 / 4$ lb. $40 c, 1 b$. $\$ 1.35$.

\section{CRESS OR PEPPERGRASS-}

(German) Kresse

A useful salad plant. It gives a pungent relish mixed with Lettuce or other salad plants. Sow the seed thickly, at frequent intervals, for a succession, in drills one foot apart.

Extra Curled. Very fine. Will bear frequent cutting. Pkt. 5c, oz. 10c, 1/4 lb. 30c, lb. 90c.

Water Cress. An aquatic plant, should be sown on the edges of streams in shallow water. Pkt. 15c.

\section{EGG PLANT-(German) Eier Pflanze}

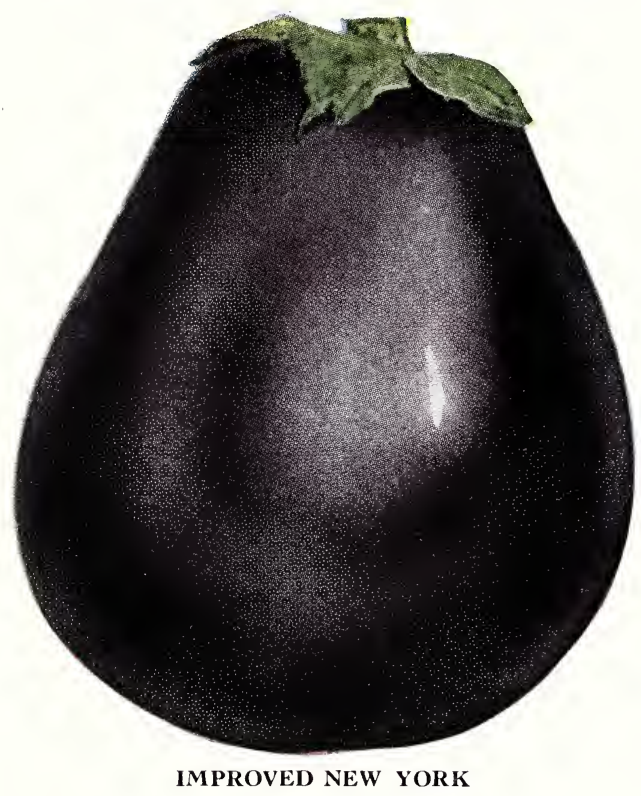

A tender annual, producing large, eggshaped fruit, and considered a great delicacy. Sow the seed in a hotbed early in March. When the plants are three inches high transplant to pots, which plunge in the same bed so that the plants may become stocky and are readily set out. When the weather becomes warm, transplant into good soil, three feet apart each way. $1 \mathrm{oz}$. will produce about 1,500 plants.

Improved New York Purple. An improved variety of the Round Purple; of deeper color, larger size and finer quality. Pkt. 10c, oz. 50c, 1/4 lb. \$1.35.

Black Beauty. Best for northern states. Earliest good market variety. Pkt. 10c, oz. 50c, $1 / 4$ lb. $\$ 1.35$.

\section{ENDIVE-(German) Endivien}

This vegetable is highly esteemed as a salad for Fall and Winter use. For an early supply sow in April or May; for general crop, delay sowing until latter part of June. When the plants are three or four inches high, transplant one foot apart each way, and keep free from weeds until the leaves are six or eight inches long; then blanch by gathering them carefully together when perfectly dry and tying by tips in a conical form to exclude light and air. Broad-leaved Batavian. Leaves broad, nearly plain. Pkt. 5c, oz. 15c, $1 / 4$ lb. 40c, lb. $\$ 1.20$.

Green Curled. Moss-like appearance, beautifully curled. Pkt. 5c, oz. 15c, $1 / 4$ lb. 40c, lb. $\$ 1.20$.

Witlof Chicory. French Endive. A most appetizing and delicious salad. Pkt. 10c, oz. 50c, $1 / 4$ lb. $\$ 1.50$.

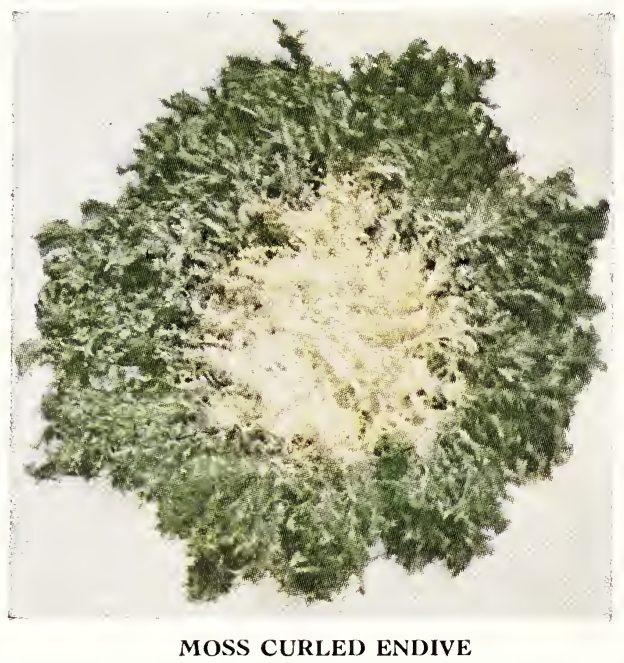

KOHL-RABI-(German) Kohlrabi

Sometimes called Overground Turnip. Sow the seed frequently through June for a succession in rows two feet apart; thin the plants to one foot in the rows.

Early White Vienna. Flesh white and tender; very productive. Pkt. 5c, oz. 20c, $1 / 4$ lb. 60c.

Early Purple Vienna. Very hard, flesh of a purple color. Pkt. 5c, oz. 25c, $1 / 4$ lb. 65c.

\section{LEEK-(German) Lauch}

A wholesome and useful vegetable. Sow in April in drills one foot apart and one inch deep; thin the plants to ten inches. $1 \mathrm{oz}$. for 1,000 plants.

Large American Flag. A standard variety. Pkt. 5c, oz. 20c, $1 / 4$ lb. 60 c, lb. $\$ 1.90$. 


\title{
Harvey's Lettuce
}

\author{
LETTUCE-(German) Letlich
}

For an early supply sow in hot-beds in March, and for main crop in the Spring as soon as the ground can be worked. Thin or transplant when one inch high to one foot apart for heading. Hoe frequently to prevent them from going to seed. $1 \mathrm{oz}$. will sow a bed of 120 square feet.

May King. The best early market variety. A very rapid grower. Heads uniform and compact, outer leaves smooth and of a beautiful light green and delicate yellow heart. Pkt. 5c, oz. 15c, $1 / 4$ lb. $45 c, 1 b . \$ 1.40$.

Hanson. This variety for outdoor culture cannot be excelled. The heads grow to a remarkable size, and are sweet, tender and crisp, even to the outer leaves. Pkt. 5c, oz. 15c, $1 / 4 \mathrm{lb}$. $50 \mathrm{c}, \mathrm{lb} . \$ 1.50$.

Early Curled Silesia. Good either for forcing or open ground. Pkt. 5c, oz. 15c, 1/4 lb. 50c, lb. $\$ 1.50$.

Black-seeded Simpson. Like the Silesia, this variety does not form a head, but differs from that variety in being much lighter in color. Stands the heat well and is well suited for forcing. Pkt. 5c, oz. 15c, 1/4 lb. 40c, lb. $\$ 1.35$.

Big Boston. An early, large heading variety, may be used either for forcing or open ground. One of the best for market gardeners' use. Pkt. 5c, oz. 15c, 1/4 lb. 45c, lb. $\$ 1.40$.

Salamander. Fine, compact, light colored heads which resist the Summer heat admirably. Pkt. 5c, oz. 15c, 1/4 lb. 40c, lb. $\$ 1.35$.

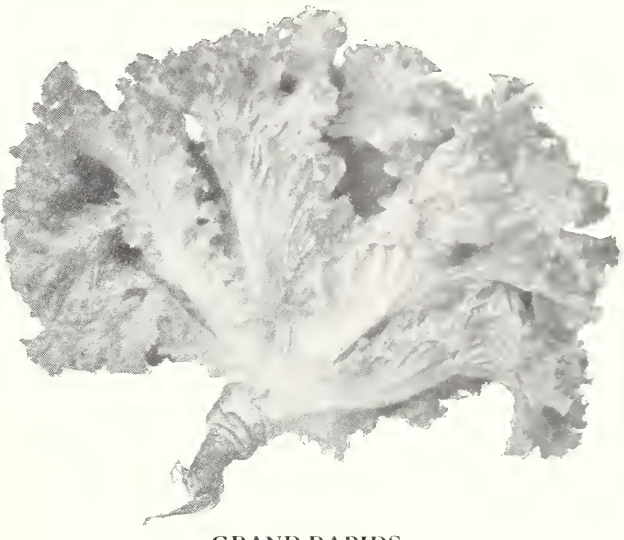

GRAND RAPIDS
Iceberg. Round, solid heads; cream yellow heart. Pkt. 5c, oz. 20c, 1/4 lb. 50c, lb. \$1.65.

Grand Rapids. Good forcing variety. Pkt. 5c, oz. $20 \mathrm{c}, 1 / 4$ lb. 50c, lb. $\$ 1.65$.

Crisp as Ice. Broad, thick, very crisp leaves, desirable for home gardens. Pkt. 10c, oz. 30c, 1/4 lb. 85c, lb. $\$ 2.75$.

Prize Head. Large, loose heads of a bright green; leaves beautifully frilled at the edge and washed with red, giving it a very unique and handsome appearance. Pkt. 5c, oz. 20c, 1/4 lb. 50c, lb. $\$ 1.75$.

New York or Wonderful. A very large and solid variety, showing but little tendency to run to seed. The color is a clear, deep apple green on the outside, the inside being yellowish white. Pkt. 5c, oz. 25c, $1 / 4$ lb. $75 \mathrm{c}, \mathrm{lb} . \$ 2.25$.

Paris Cos. One of the best of the Cos varieties; large and exceedingly tender. Pkt. 5c, oz. 20c, 1/4 lb. $50 \mathrm{c}, \mathrm{lb} . \$ 1.60$.

\section{MELON, Musk-(German) Melone}

Select light warm soil; plant in hills six feet apart each way. The hills should be prepared by digging out the soil a foot deep and thoroughly mixing in a couple of shovelfulls of well-rotted manure, filling up a little above the level. Planting should be deferred until warm, settled weather. 1 oz. will plant 100 hills.

Rockyford. Originated in Colorado; the most popular melon of the times; known everywhere and sought for by lovers of good melons. Pkt. 5c, oz. 15c, 1/4 lb. $40 \mathrm{c}, \mathrm{lb} . \$ 1.50$.

Paul Rose. Originated from the Osage and Rockyford. Flesh orange red, firm and sweet to the rind. For table use this is the best melon extant. Pkt. 5c, oz. $15 \mathrm{c}, 1 / 4 \mathrm{lb} .40 \mathrm{c}, 1 \mathrm{~b} . \$ 1.50$.

Tip Top. This excellent yellow fleshed variety is one of the most desirable sorts either for the home garden or the market grower who ships to near markets. The fruits are of medium to large size with thick, rich colored flesh of superior quality. The vines are vigorous and productive. Pkt. 5c, oz. 20c, 2 oz. 35c, 1/4 lb. 55c, lb. $\$ 1.75$.

Bender's Surprise. This new Melon has a thin cream colored skin, and thick salmon colored flesh. Early, very productive, and of delicious flavor. Externally it resembles White Japan, but grows to twice the size. Pkt. 5c, oz. 15c, 1/4 lb. 40c, lb. $\$ 1.25$.

Nutmeg. Skin deep green; flesh greenish yellow. Very fragrant and delicious. Pkt. 5c, oz. 15c, 1/4 lb. 40c, lb. $\$ 1.25$.

Defender Melon. Medium size, salmon flesh, and delicious flavor, oval shape, slightly ribbed and slight netting. Pkt. 5c, oz. 15c, 1/4 lb. 40c, lb. $\$ 1.50$.

Irondequoit. The best melon in cultivation; flesh dark orange and firm. Deliciously flavored. Pkt. 5c, oz. 25 c, $1 / 4$ lb. 75 c, lb. $\$ 2.25$.

Emerald Gem. New, small, extra early; skin dark green; flesh orange and of delicious flavor. Pkt. 5c, oz. 15c, $1 / 4$ lb. 40c, lb. $\$ 1.25$.

Osage also known as "Miller's Hrbrid" and "New Princess"). A strong growing and productive green skinned variety; flesh a rich salmon color and very thick. It makes a fine appearance and is a good selling melon. Pkt. 5c, oz. 15c, 1/4 lb. 40c, lb. $\$ 1.25$.

Special Price on Quantities

\section{MELON, Water-(German) W' assermelone}

Mountain Sweet. A standard market variety. Skin marbled green; flesh red, firm and sweet. Pkt. 5c, oz. 10c, 1/4 lb. 30c, lb. $\$ 1.00$.

Cole's Early. Finest for northern use. Pkt. 5c, oz. $10 \mathrm{c}, 1 / 4$ lb. 30c, 1b. 85c.

Black Spanish. An old variety, one of the richest, medium size, dark green skin, red flesh. Pkt. 5coz. 10c, $1 / 4$ lb. 30c, lb. $\$ 1.00$.

Citron. Red seeded, medium size; used for sweet; meats and preserves. Pkt. 5c, oz. 10c, 1/4 lb. 30c, lb. $90 \mathrm{c}$. 


\section{MUSHROOM SPAWN-(German) Essbare Blaetterschwamme}

Mushroom beds may be prepared in a warm cellar or shed in Winter, or in the open air in Summer. Collect daily the fresh horse manure from the stable, and lay it in a heap to ferment; turn and mix it well once a week, and when well and equally fermented, which will be in about three weeks, it will then be ready for the beds. The beds should be about four feet wide, and any length required for a supply. Place the prepared dung two feet deep on the beds, mix thoroughly with the earth, and beat or press it firmly down with the back of the spade; in this state it should remain until the temperature has become sufficiently mild, which may be ascertained by thrusting a stick into the different portions of the bed. Pieces of the spawn of the size of a walnut should then be inserted about two inches deep, and six inches apart; cover with loamy soil two inches deep, and press down evenly and firmly.

Fresh Milltrack Spawn. In bricks. Per brick 25c, per dozen bricks $\$ 2.50$.

\section{MUSTARD-(German) Senf}

Used as a salad early in Spring with Lettuce and Cress. Sow at intervals thickly, in rows six inches apart. Cut when about two inches high.

Giant Southern Curled. Grows nearly 2 feet high, and has fine curled leaves which are excellent for salad. Very popular in the Winter and early Spring. Pkt. 5c, oz. 10c, 1/4 lb. 25c, lb. 70c.

\section{OKRA OR GUMBO-(German) Essbarer}

This vegetable produces long, nutritious pods, which, when young, are used in soups and stews, to which they impart a rich flavor. It is of easy culture, grows freely and bears abundantly. To be sown at the usual time of all tender vegetables, in drills two inches deep, and two feet apart in the rows.

White Velvet Pod. A distinct variety; pods large, smooth and abundant. Pkt. 5c, oz. 15c, $1 / 4$ lb. 30c, lb. $85 \mathrm{c}$.

\section{ONION-(German) Zwiebel}

The Onion should have a clean, loamy and very rich soil. The use of well-rotted compost is very beneficial, and Onions will do well if sown on the same piece of land for a succession of years. Sow seed as early as possible, in drills fourteen inches apart and half an inch deep. As Onions grow on top of the ground they may be allowed to remain pretty thick, no matter if they crowd each other. In hoeing, which should be frequently done, do not cover the young bulbs with earth. $1 \mathrm{oz}$. of seed will sow a bed 5 by 20 feet.
Yellow Globe Danvers. A thick, heavy, straw-colored Onion; mild flavored and yields abundantly. Ripens early and keeps well, the standard market variety of this section. Pkt. 5c, oz. 20c, $1 / 4$ lb. 60c, lb. $\$ 1.80$.

Southport Yellow Globe. Oz. 25c, 1/4 lb. 65c, lb. $\$ 2.00$.

Large Red Wethersfield. A large flat variety; skin deep red, flesh purplish white; very productive, good keeper, popular in the eastern markets. Pkt. 5c, oz. 20c, $1 / 4$ lb. 60c, lb. $\$ 1.85$.

White Portugal, or Silver Skin. A fine large white Onion of delicate flavor, but a poor keeper. Pkt. 5c, oz. 25c, $1 / 4$ lb. 80c, lb. $\$ 2.65$.

White Pickling. A small, clear white Onion; extensively used for pickling, very handsome. Pkt. 5c oz. 25c, $1 / 4$ lb. 75 c, lb. $\$ 2.50$.

White Globe. A very handsome late variety; a large cropper, and of good quality. Pkt. 10c, oz. 30c, $1 / 4$ lb. 85c, lb. $\$ 2.65$.

Prize Taker. A large foreign variety; equal in quality to the Spanish varieties. To reach perfection should be started in a hot-bed and transplanted. Pkt. 5c, oz. 25c, $1 / 4$ lb. 60c, lb. $\$ 1.90$.

Ebenezer. A yellow globe variety, famous for their keeping qualities. We have the true variety. Pkt. 10c, oz. 25c, $1 / 4$ lb. 70c, lb. $\$ 2.25$.

Special Price on Quantities

\section{Onion Sets}

Plant as early in Spring as the ground can be worked, in rows one foot apart. We handle only Sets which are always hard and in good condition.

White Onion Sets. Yellow Onion Sets. Ebenezer Onion Sets. Market Price.

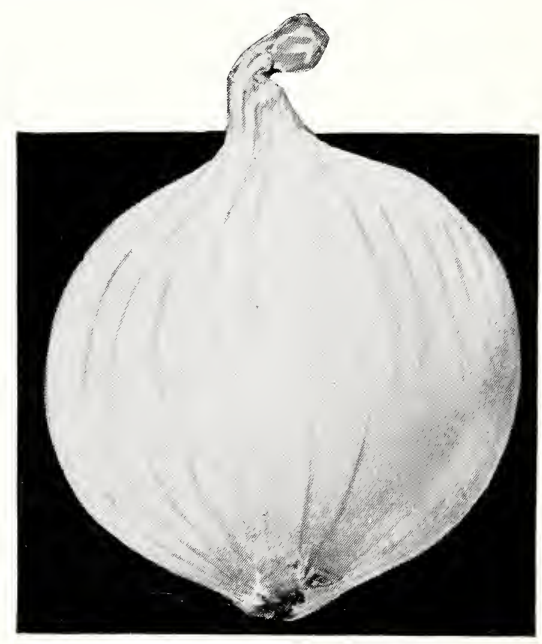

YELLOW GLOBE DANVERS

\section{Harvey's Garden Collection}

1 pkg. Beans, Pencil Pod; 1 pkg. Beans, Stringless; 1 pkg. Beet, Detroit; 1 pkg. Carrot, Nantes; 1 pkg. Cucumber, Fortune; 1 pkg. Cabbage, Chinese; l pkg. Lettuce, Prizehead; 1 pkg. Parsley, Moss Curled; 1 pkg. Peas, Little Gem; 1 pkg. Peas, Laxtonian; l pkg. Radish, Scarlet Globe; 1 pkg. Turnip, White Globe.

12 Splendid Varieties for 70c 


\section{PARSNIPS-}

\section{(German) Pastinake}

Sow in rich, deep and well-manured soil, as early as the weather will permit, in rows fifteen inches apart and one-half inch deep; thin out to five inches apart. They are improved by frost, and are usually left in the ground all Winter, and dug as needed.

Hollow Crown. One of the best either for table or stock. Pkt. 5c, oz. 10c, $1 / 4$ lb. $25 \mathrm{c}, \mathrm{lb} .70 \mathrm{c}$.

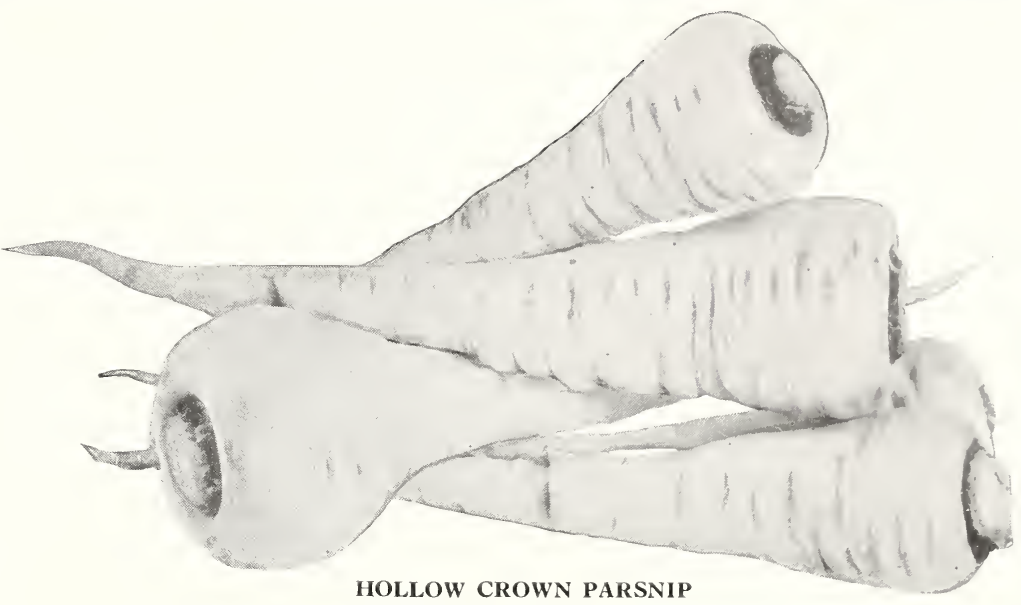

Large Dutch. Roots very long and smooth. Pkt. 5c, oz. 15c, $1 / 4$ lb. 30c, lb. $\$ 1.00$.

\section{PARSLEY-(German) Petersilie}

Parsley seed germinates very slowly, and frequently remains in the ground from two to three weeks without showing any signs of vegetation. Seeds sown out of doors should be soaked in warm water at least twenty-four hours previous to planting. When the plants are two or three inches high, thin out to four inches apart in the rows.

Champion Moss Curled. A very select stock; leaves beautifully curled, the best for garnishing. Pkt. 5c, oz. 10c, $1 / 4$ lb. 30c, lb. 85c.

Plain Parsley. The leaves of this variety are plain. It is hardier than the curled variety; good for flavoring. Pkt. 5c, oz. 10c, 1/4 lb. 30c, 1b. 85c.

Turnip Rooted. The root resembles a small parsnip; extensively used for soups. Pkt. 5c, oz. 15c, 1/4 lb. 35c, lb. \$1.10.

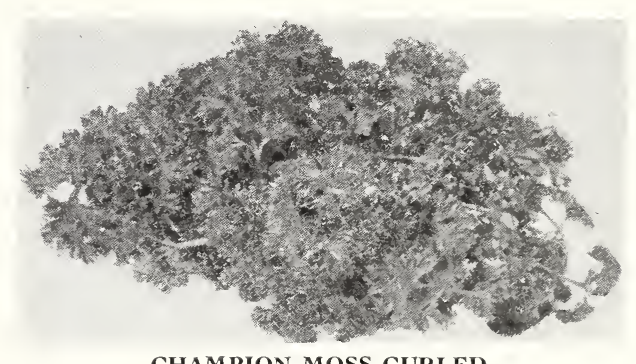

\section{PEPPERS-(German) Pfeffer}

Cultivated largely for pickles. Sow early in Spring in hot-bed. Transplant when the weather is favorable, in rows eighteen inches apart and ten inches in the rows.

Chinese Giant. Double the size of Ruby King. The largest in existence. Extremely mild and sweet, can be served sliced like tomatoes. Pkt. 10c, oz. 60c, $1 / 4$ lb. $\$ 1.85$.
Cayenne. Long, thick pointed pod; extremely strong and pungent. Pkt. 10c, oz. 35c, 1/4 lb. $\$ 1.15$.

Hot Squash. A hot, tomato shaped variety. Pkt. 10c, oz. $40 \mathrm{c}, 1 / 4$ lb. $\$ 1.15$.

Sunny Brook. Smooth, deep green, turning to red when ripe. Very mild, sweet flavor. Pkt. 10c, oz. $50 \mathrm{c}, 1 / 4 \mathrm{lb} . \$ 1.35$.

Large Bell or Bull Nose. Standard sort; early, sweet and of good flavor. Pkt. 10c, oz. 30c, 1/4 lb. \$1.00.

Harris Early Giant. Earliest large sweet pepper, heavy yielder. One of the best. Pkt. 10c, oz. 60c, $1 / 4$ lb. $\$ 2.00$.

Ruby King. Large, bright red and remarkably mild and pleasant. Pkt. 10c, oz. 40c, 1/4 lb. $\$ 1.15$.

Pimento or Perfection. Pkt. 10c, oz. 40c, $1 / 4 \mathrm{lb}$. $\$ 1.15$.

World Beater. Mild, sweet fruit that is deep green, turning red when ripe. Matures medium early. Pkt. 10c, oz. 40c, 1/4 lb. $\$ 1.15$.

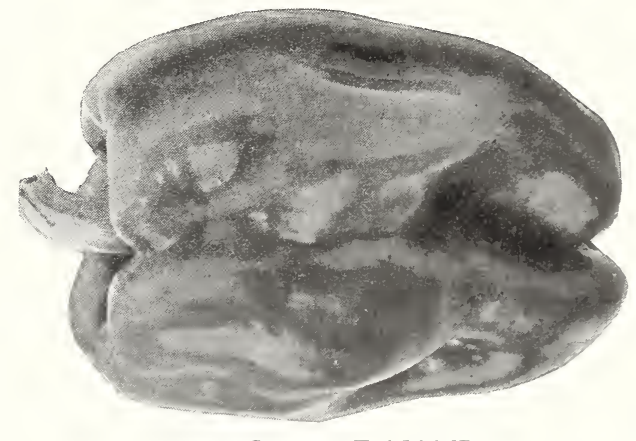

CHINESE GIANT PEPPER

\section{PUMPKIN-(German) Kurbis}

Cultivated usually among corn. Treatment same as squashes.

Connecticut Field. Best for stock. Pkt. 5c, oz. 10c, $1 / 4 \mathrm{lb} .20 \mathrm{c}, \mathrm{lb} .50 \mathrm{c}$.

Sugar. Medium size; fine quality. Excellent for cooking. Pkt. 5c, oz. 10c, $1 / 4$ lb. 30c, lb. $\$ 1.00$.

Mammoth King. Grows to an immense size, three feet or more in diameter, weighing from 100 to 200 pounds. Pkt. 10c, oz. 25c, $1 / 4$ lb. $75 \mathrm{c}, 1 \mathrm{~b}$. $\$ 2.50$.

Special Price on Quantities 


\section{Good Garden Peas}

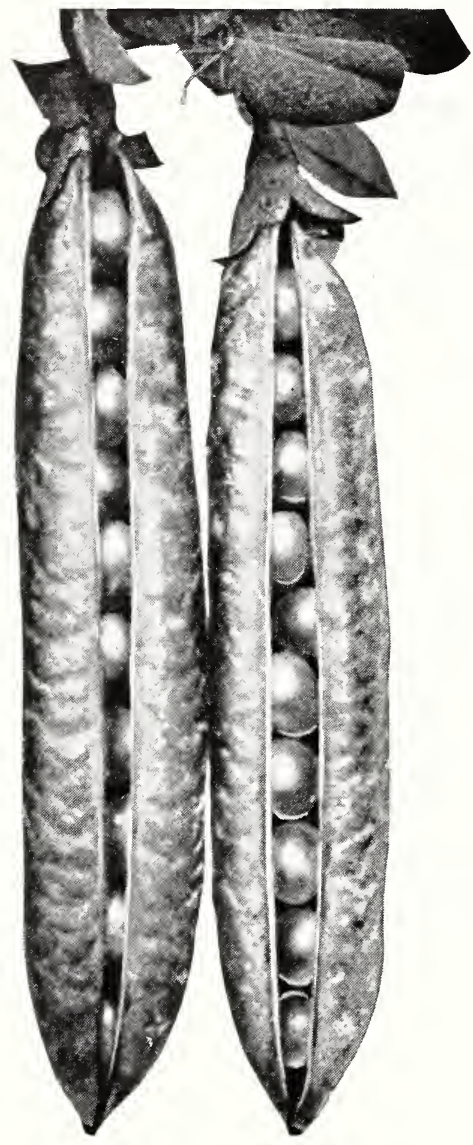

LAXTONIAN IS A FINE VARIETY TO GROW IN THE GARDEN

Nott's Excelsior. A dwarf wrinkled Pea destined to take the place of the well-known American Wonder; the vines are larger and more vigorous; equally as early and much more prolific; in sweetness and quality they are equal to any. Pkt. 10c, lb. 25c, 10 lbs. $\$ 2.00$.

American Wonder. A very early green wrinkled dwarf variety; peculiarly suited to the private garden; height, ten inches. Pkt. 10c, lb. 25c, 10 lbs. $\$ 2.00$.

Premium Gem. A dwarf wrinkled variety; height, one foot. Pkt. $10 \mathrm{c}, \mathrm{lb} .25 \mathrm{c}, 10$ lbs. $\$ 2.00$

Alaska. The earliest Pea known. Lb. 25c, 10 lbs. \$1.90.

Telephone (Harvey's Improved Dark Pod). An extra selected strain with very large dark green pods, always coming true; the result of careful breeding. The improvement over the ordinary kind is so marked that we consider this the best Telephone type now obtainable. Pkt. 10c, lb. 25c, 10 lbs. \$2.00.

Admiral Dewey. A new variety of Telephone type, with larger pods of dark green color. Pkt. 10c, lb. 25c, 10 lbs. $\$ 2.00$.

Alderman. Lb. 25c, 10 lbs. \$2.00.

Duke of Albany. Lb. 25c, 10 lbs. \$1.90.

Improved Stratagem. A dwarf wrinkled variety. Lb. 35c, 10 lbs. $\$ 3.00$.

Champion of England. Lb. 25c, 10 lbs. \$2.00.

Thos. Laxton. Lb. 25c, 10 lbs. \$2.00.

Laxtonian. A fine large podded dwarf Pea. Wonderful flavor. Lb. $25 c, 10$ lbs. $\$ 2.10$.

Special Price on Quantities

\section{LONG SEASON COLLECTION OF GARDEN PEAS}

In this collection we offer four splendid kinds that will give you peas for your table over a period of three weeks. Sow them as soon as the weather permits. If a longer season is desired make a second sowing ten days after the first.

\section{Alaska American Wonder \\ Laxtonian Champion of England}

\section{Special Collection Prices}

One package each of the above four kinds. $\quad \$ \quad .30$

One half-pound each of the above four kinds.

One pound each of the above four kinds.

Two pounds each of the above four kinds.

.50
.90
1.85

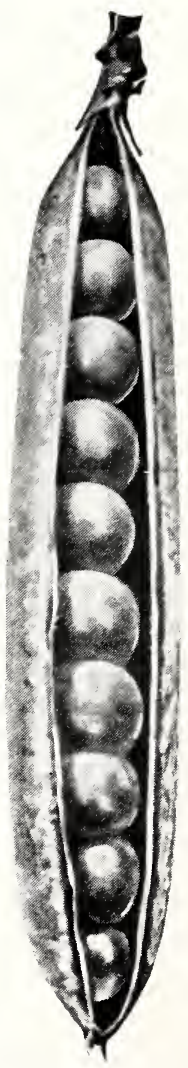

The same high quality seeds go into our Garden Size packages as we furnish to the Commercial Vege table Grower and Florist whose living depends on the quality of the seed he sows. 


\section{RADISH-(German) Rettich}

The Radish will succeed best in a rich, sandy loam. For early use sow in hot-beds in February or March, and in the open air as soon as the ground can be worked. For a succession sow every two weeks until June. The Winter varieties should be sown in August and treated similar to Turnip. $1 \mathrm{oz}$. of seed will sow a bed 5 by 20 feet.

Non Plus Ultra. Extra Early Scarlet; one of the best for forcing; very small top. Pkt. 5c, oz. 10c, 1/4 lb. $30 \mathrm{c}, \mathrm{lb} . \$ 1.00$,

Scarlet Turnip. A small, round, early variety; tender and crisp. Pkt. 5c, oz. 10c, $1 / 4$ Ib. 30c, lb. $\$ 1.00$, 5 lbs. $\$ 3.90$

Scarlet Turnip, White Tipped. An early variety; of medium size and handsome appearance. Pkt. 5c, Oz. 10c, 1/4 lb. 30c, lb. 90c.

White Turnip. Similar to Scarlet Turnip; a few days later. Pkt. 10c, oz. 15c, 1/4 lb. 40c, lb. \$1.25.

Improved Scarlet Globe. Excellent for forcing, early, handsome color, mild flavor. Pkt. 5c, oz. 10c, $1 / 4$ lb. 30c, lb. $85 c, 5$ lbs. $\$ 3.50$.

Icicle. A long transparent White Radish of exceptionally delicate flavor. Never tough or stringy. One of the very best for the home garden. Pkt. 5c, oz. $10 \mathrm{c}, 1 / 4 \mathrm{lb} .25 \mathrm{c}, \mathrm{lb} .80 \mathrm{c}$.

Chinese Rose Winter. Considered the best for Winter use; medium size and very tender. Pkt. 5c, oz. $10 \mathrm{c}, 1 / 4$ lb. $30 \mathrm{c}, \mathrm{lb} . \$ 1.00$.

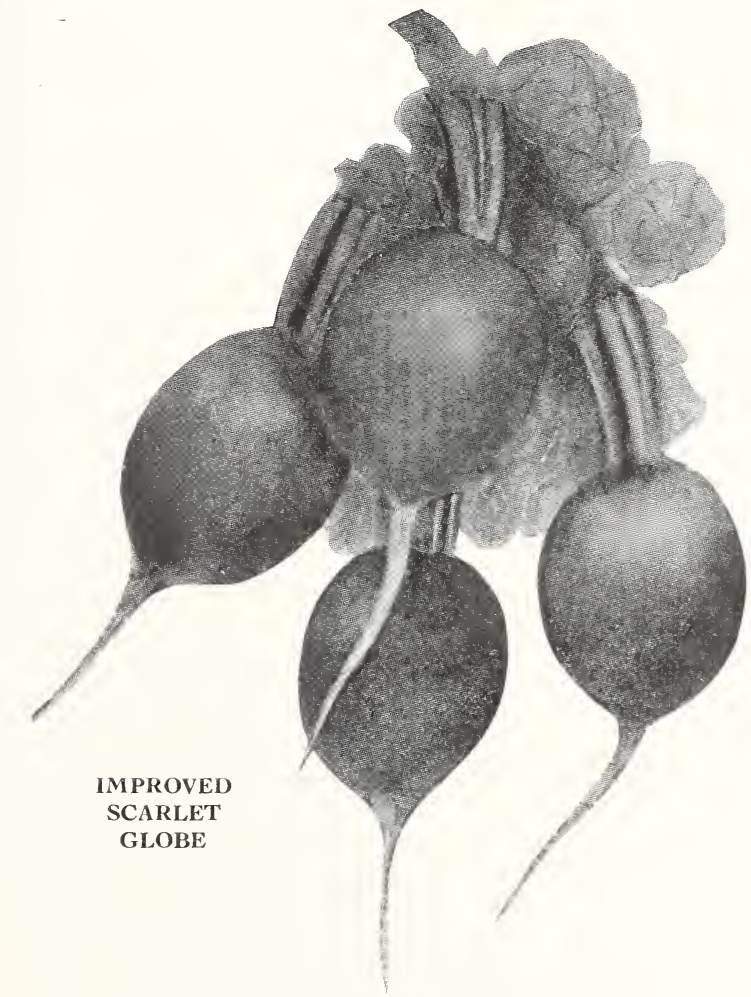

White Strasburg. A desirable Summer variety; large at the top, tapering to a point. Pkt. 5c, oz. 10c, 1/4 lb. $30 \mathrm{c}, \mathrm{lb} .85 \mathrm{c}$.

Giant White Stuttgart. A large, globe-shaped Radish, of mild flavor and snow-white skin and flesh; rapid grower; excellent for market gardeners. Pkt. 5c, oz. 10c, 1/4 Ib. 30c, 1b. $85 \mathrm{c}$.

Sparkler. The earliest Radish in cultivation; in shape globular, with rich, deep scarlet top, blending to white at the bottom. Pkt. 5c, oz. 10c, 1/4 Ib. 30c, lb. $\$ 1.00$.

Long Scarlet Short Top. Roots long, of a pinkish color; flesh white and of good flavor. Oz. 10c, 1/4 lb. 30c, 1b. $\$ 1.00$.

French Breakfast. A fine early variety; olive shaped; white tipped. Pkt. 5c, oz. 10c, 1/4 lb. 30c, lb. 85c.

Chartier. A long Radish, distinct in color from any other sort, being crimson at the top, gradually blending to a pure waxy white; may be grown to a large size before becoming pithy and unfit for use. Pkt. $5 \mathrm{c}, \mathrm{oz} .10 \mathrm{c}, \mathrm{1} / 4 \mathrm{lb} .25 \mathrm{c}$, lb. $80 \mathrm{c}$.

Long Black Spanish Winter. Grows to a large size; of oblong shape; quite solid. Pkt. $5 \mathrm{c}, \mathrm{oz} .15 \mathrm{c}, 1 / 4 \mathrm{lb}$. $40 \mathrm{c}, 1 \mathrm{~b} . \$ 1.00$.

Round Black Spanish. Similar to above except in form. Plkt. 5c, oz. 15c, 1/4 lb. 40c, Ib. $\$ 1.00$.

White Spanish Winter. Similar to Long Black, except in color. Pkt. 5c, oz. $15 \mathrm{c}, 1 / 4 \mathrm{lb} .40 \mathrm{c}, \mathrm{lb} . \$ 1.25$.

\section{SPINACH-(German) Spinat}

One package will sow 15 feet of row, one ounce for 100 feet, about 10 pounds to the acre.

Most popular of plants for greens. Plant in rich ground, in rows 12 to 14 inches apart, and cover 1 inch deep. Thin to about 6 inches apart. Cut before hot weather, when young and tender. For early Spring plants sow seed in August or September and protect with a light covering of leaves or straw.

Victoria. Large thick leaves, somewhat curled in the center; very early. $1 / 4 \mathrm{lb} .15 \mathrm{c}, \mathrm{lb} .40 \mathrm{c}, 10 \mathrm{lbs} . \$ 2.75$.

Bloomsdale Savoy. The best variety for Fall sowing. It is very hardy and produces thick, dark green leaves of excellent quality. $1 / 4 \mathrm{lb} .15 \mathrm{c}, \mathrm{Ib} .40 \mathrm{c}, 10$ lbs. $\$ 3.00$.

King of Denmark. $1 / 4$ lb. $15 \mathrm{c}, \mathrm{lb} .45 \mathrm{c}, 10 \mathrm{lbs} . \$ 4.00$.

Princess Juliana. A wonderful new thick leaf variety. One of the best. $1 / 4 \mathrm{lb} .15 \mathrm{c}, \mathrm{lb} .45 \mathrm{c}, 10 \mathrm{lbs} . \$ 4.00$.

New Zealand. Grows luxuriantly in the Summer heat. Can be cut all Summer and Fall. Pkt. 5c, oz. 10c, $\mathrm{l} / 4$ Ib. 25c, Ib. 65c.

\section{Special Price on Quantities}

\section{VISIT OUR SEED STORE WHEN IN BUFFALO}

Here we have not only one of the finest and most upto-date Seed Stores in the country, but space and equipment for handling orders from our out-of-town customers that will give them even better service than we have given them in the past.

Here vou will find just about everything for the Garden: Seeds, Plants, Shrubs, Vines, Bulbs, Trellises, Garden Hose, Sprinklers, Sprayers, Fertilizers, Insect Destroyers, Bird Seed, Gravel, Song Restorer and all Remedies for Birds as well as Cats and Dogs. Come in and visit us. 


\section{SQUASH-(German) Kurbiss}

The squash being a tender vine should not be planted until all danger from frost is past. Plant in hills, the bush varieties about four feet apart, the running kinds from six to nine feet, according to their nature. Cutting off the leading shoots of the running sorts is recommended as having a tendency to promote growth and early maturity of fruit. $1 \mathrm{oz}$. of seed will plant from 40 to 80 hills.

Early Golden Bush Scalloped. An early Summer variety; well flavored and productive. Pkt. 10c, oz. 15 c, $1 / 4$ lb. 35c, lb. $\$ 1.10$.

Cocozelle. Italian Vegetable Marrow. A bush squash. Pkt. 10c, oz. 15c, 1/4 lb. 45c, lb. $\$ 1.45$.

Mammoth Crook Neck. Double the size of the ordinary Crook Neck, often two feet in length; quality good. Pkt. 5c, oz. 15c, 1/4 lb. 35c, lb. \$1.10.

Boston Marrow. A standard Fall squash, of rich orange color; very productive and keeps well. $\mathbf{O z}$. $15 \mathrm{c}, 1 / 4 \mathrm{lb} .30 \mathrm{c}, \mathrm{lb} .90 \mathrm{c}$.

Golden Hubbard. A true Hubbard Squash, except in color, which is a bright orange red; shell warty, hard and strong. The fruits are uniform in size and weighing from 6 to 8 lbs. and same shape as Hubbard; cooks dry and good flavor. Pkt. 10c, oz. 15c, 1/4 lb. 45c, lb. \$1.35.

Warted Hubbard. The best of all Winter varieties; flesh bright yellow, very sweet and dry, skin green when ripe, an excellent keeper. Pkt. 10c, oz. 15c, $1 / 4$ lb. 40c, lb. $\$ 1.20$.

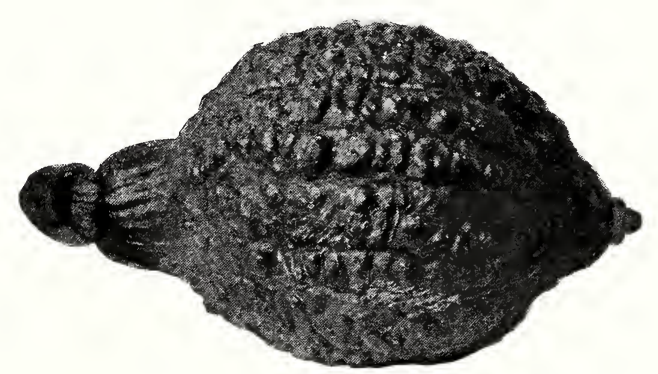

WARTED HUBBARD

Mammoth Chili. Grows to an immense size, often attaining $200 \mathrm{lbs}$. in weight; excellent for stock. Oz. 15c, 1/4 lb. 50c, lb. $\$ 1.75$.

Blue Hubbard. A new variety obtained by selection from the original Hubbard. The fruit is of a grayblue color, grows very large and keeps remarkably well as the shell is extremely hard. The quality is equal to or even better than the original Hubbard. Pkt. 10c, oz. 25c, 1/4 lb. 60c, lb. \$1.90.

Italian Squash (Zucca Pergola). Grows three feet long and three inches in diameter. Used for slicing and frying. Pkt. 10c, oz. 30c, 1/4 lb. \$1.00, lb. $\$ 3.25$.

\section{SALSIFY OR VEGETABLE OYSTER- (German) Bocksbart}

Select light, rich soil. Sow the seed early in Spring, in rows twelve inches apart. When the plants are two or three inches high thin out to six inches from each other in the rows. It is perfectly hardy and may be treated same as Parsnips. 1 oz. of seed will sow 50 feet of row.

Mammoth Sandwich Island. A new variety; grows double the size of the ordinary kind. Pkt.5c, Oz. 25c, $1 / 4$ lb. 70c, lb. $\$ 2.10$.

\section{TOMATOES-(German) Liebsapfel}

Sow the seed in March in a hot-bed. When the plants are two or three inches high, thin them out and set in pots, or set in another bed to give them room and make them "stocky." When five or six inches high, if the weather be warm and settled, transplant to the open ground, setting the plants four feet apart each way. The Tomato requires a sunny location and rich soil to produce handsome specimens and a good crop. One ounce of seed will produce 3,000 plants.

June Pink. An extra early variety, coming in with Earliana, of which it is a selection. The fruit, however, has an Acme color which, with its earliness, makes it a very desirable acquisition. The fruit is round, grows in clusters, and bears throughout the season. Pkt. 10c, oz. 50c, 1/4 lb. $\$ 1.50,1 b$. $\$ 4.75$.

Spark's Earliana. A new, extra early variety; large size, handsome shape, bright red color; a most profitable variety for the market gardener. Pkt. 5c, oz. 40c, $1 / 4$ lb. $\$ 1.25$, lb. $\$ 3.75$.

Chalk's Early Jewel. Ripens later than Spark's Earliana, but more desirable for home use, as fruits are thicker through and more solid; color bright scarlet and quality good. Pkt. 5c, oz. 35c, 1/4 lb. $\$ 1.25,16 . \$ 3.50$.

Trucker's Favorite. One of the best market garden varieties; color purplish red, of large size, even growth, and prolific bearer. Pkt. 5c, oz. 35c, $1 / 4 \mathrm{lb}$. $\$ 1.00$, lb. $\$ 3.75$.

Dwarf Champion. A distinct and valuable sort, having a strong main stem, which enables it to support its fruit well up from the ground. The crop ripens up early and evenly. It is a good cropper, smooth, medium in size, Acme in color. Pkt. 10c, oz. 50c, $1 / 4$ lb. $\$ 1.40$, lb. $\$ 4.75$.

Livingston's New Stone. A bright red, perfectly smooth and solid tomato; thicker from stem end to blossom end than most varieties; for all around purposes we consider this the best one in the list. Pkt. 5c, oz. 50c, $1 / 4$ lb. $\$ 1.50$, lb. $\$ 3.75$.

\section{Special Price on Quantities}

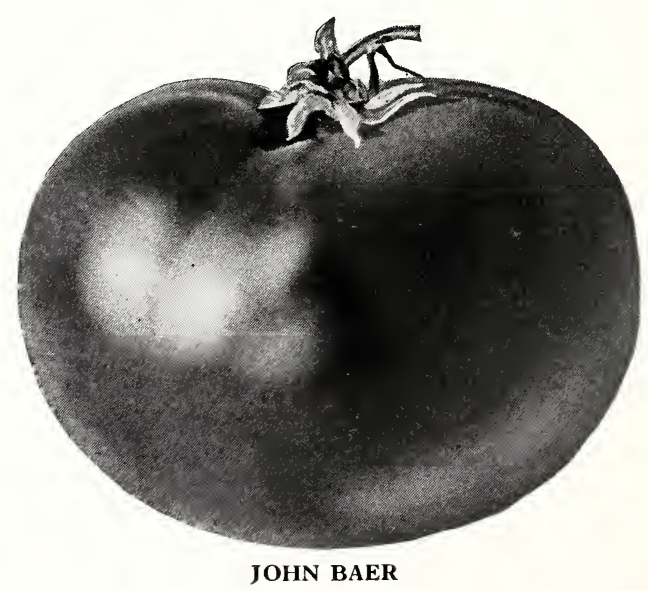




\section{TOMATOES - Continued}

Bonny Best. A very early and desirable variety. The fruits are most attractive in shape, solidity and color, which is bright scarlet from outside to center. The vines are strong and vigorous, producing a good crop of round, globe-shaped fruits which ripen more uniformly than other early sorts. A favorite with market gardeners. Pkt. 5c, oz. 35c, 1/4 lb. \$1.00, lb. $\$ 3.50$.

Acme. Very early; color reddish purple. Pkt. 5c, oz. 40 c, $1 / 4$ lb. $\$ 1.25$, lb. $\$ 3.75$.

John Baer. One of our earliest and most profitable varieties, fruit globe-shaped, bright scarlet in color, good size, solid, coreless and with free seeds. Vigorous and prolific. Pkt. 5c, oz. 35c, 1/4 lb. $\$ 1.00,1 b . \$ 3.75$.

Ponderosa. The largest Tomato grown; deep red in color, smooth shape, solid meat, and in every way a perfect Tomato; should be in every garden. Pkt. $10 \mathrm{c}, \mathrm{oz} .55 \mathrm{c}, 1 / 4$ lb. $\$ 1.60,1 \mathrm{~b} . \$ 5.50$.

Marglobe. Globe shaped fruit of deep red color. Very smooth. Medium late, ripening right after John Baer and Bonny Best. Rust resistant. Pkt. 10c, oz. 50c, $1 / 4$ lb. $\$ 1.45$, lb. $\$ 4.75$.

Greater Baltimore. A mid-season or main crop variety. Very popular. Fruits medium to large in size. Solid, meaty and uniform in ripening. The color is a rich bright red. Pkt. 10c, oz. 40c, $1 / 4$ lb. $\$ 1.25$, lb. $\$ 4.00$.

Golden Queen. Pkt. 10c, oz. 50c.

Red Cherry. Pkt. 10c, oz. 50c.

\section{TURNIPS - (German) Rube}

For early use sow as early as the ground can be worked in the Spring. For Fall and Winter use the seed should be sown from the middle of July to the middle of August. The swedes should be sown in June, the plants thinned out to six inches in the rows.

Extra Early Milan. A week earlier than any other variety; producing good sized bulbs before others have begun to form. Bulbs white, with purple top, round flattened and solid, with very slender tap root; the best grown for early market. Oz. 15c, 1/4 lb. $30 \mathrm{c}, 1 \mathrm{~b} .85 \mathrm{c}$.

White Egg. An excellent variety; nearly oval or eggshaped; flesh firm, fine grained and of snowy whiteness. Particularly desirable for the table. Pkt. 5c, oz. 10c, $1 / 4$ lb. 25c, lb. 70c.

Purple Top Strap Leaf. The most popular kind in cultivation; matures quickly; flesh white and sweet. Pkt. 5c, oz. 10c, 1/4 lb. 25c, lb. 55c.

Golden Ball. A round, smooth variety of fine quality; skin bright yellow, good keeper. Pkt. 5c, oz. 10c, $1 / 4$ lb. 25c, lib. 70c.

Purple Top White Globe. A large, globe-shaped variety; fine for market purposes. Pkt. 5c, oz. 10c, $1 / 4$ lb. 25c, lb. 55c.

Cowhorn, or Long White. Recommended as a soil renovator, and largely used for that purpose. The roots being long, go deep into the soil and loosen and lighten it up as well as adding a quantity of nitrogen to it. The agricultural papers have explained the value of it as a fertilizer. Oz. 10c, 1/4 lb. 20c, 1b. 65c.

\section{Rutabaga, or Swedish Turnip}

American Improved Purple Top. The earliest variety; large, handsome roots, and good keeper. Pkt. 5c, oz. 10c, 1/4 lb. 25c, lb. 70c.
Sweet German or Russian. A large, white variety; first-rate keeper, and good either for table or stock. Oz. 10c, 1/4 lb. 25c, 1b. 80c.

Improved Rhode Island. Grows to a large size; flesh firm, solid and sweet; good keeper. Oz. 10c, 1/4 lb. 30c, lb. $85 \mathrm{c}$.

\section{SWEET AND MEDICINAL HERBS}

Sow the seed of any of the kinds mentioned in the following list in April or May. Keep free from the weeds, and as they come into flower cut the stems and leaves on a fair day, and spread in a shady place to dry for Winter use. When cured wrap them in paper to exclude the air, and store them in a place free from dampness.

\begin{tabular}{|c|c|c|c|}
\hline Anise....... & $\begin{array}{l}\text { Pkt. } \\
\$ .10\end{array}$ & $\begin{array}{r}\text { Oz. } \\
\$ .25\end{array}$ & $\begin{array}{r}\text { Lb. } \\
\$ 2.50\end{array}$ \\
\hline Basil (Sweet) . . . . . . . . . & .10 & .25 & 2.75 \\
\hline Caraway .............. & .10 & .15 & .85 \\
\hline Coriander. . . . . . . . . & .10 & .15 & .85 \\
\hline Dandelion. . . . . . . . . . . & .10 & .50 & 6.00 \\
\hline Dill................... & .05 & .10 & .70 \\
\hline Fennel (Sweet).... & .10 & .25 & 2.00 \\
\hline Lavender. . . . . . . . . . & .10 & .60 & 6.00 \\
\hline Marjoram (Sweet) . . . . . . . & .10 & .30 & 2.50 \\
\hline Savory (Summer). . . . . . . . & .10 & .25 & \\
\hline Sage (Broad-leaved) ........ & .10 & .20 & 2.00 \\
\hline Sorrel. . . . . . . . . . . . & .10 & .20 & 1.65 \\
\hline Thyme.............. & .10 & .50 & 3.50 \\
\hline
\end{tabular}

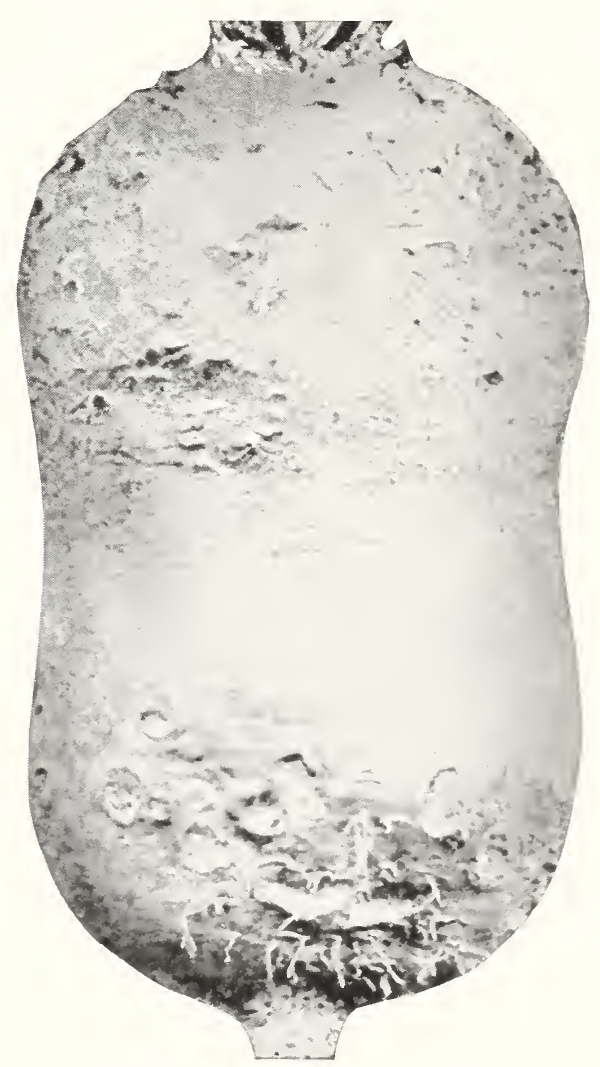

MAMMOTH LONG RED MANGEL 


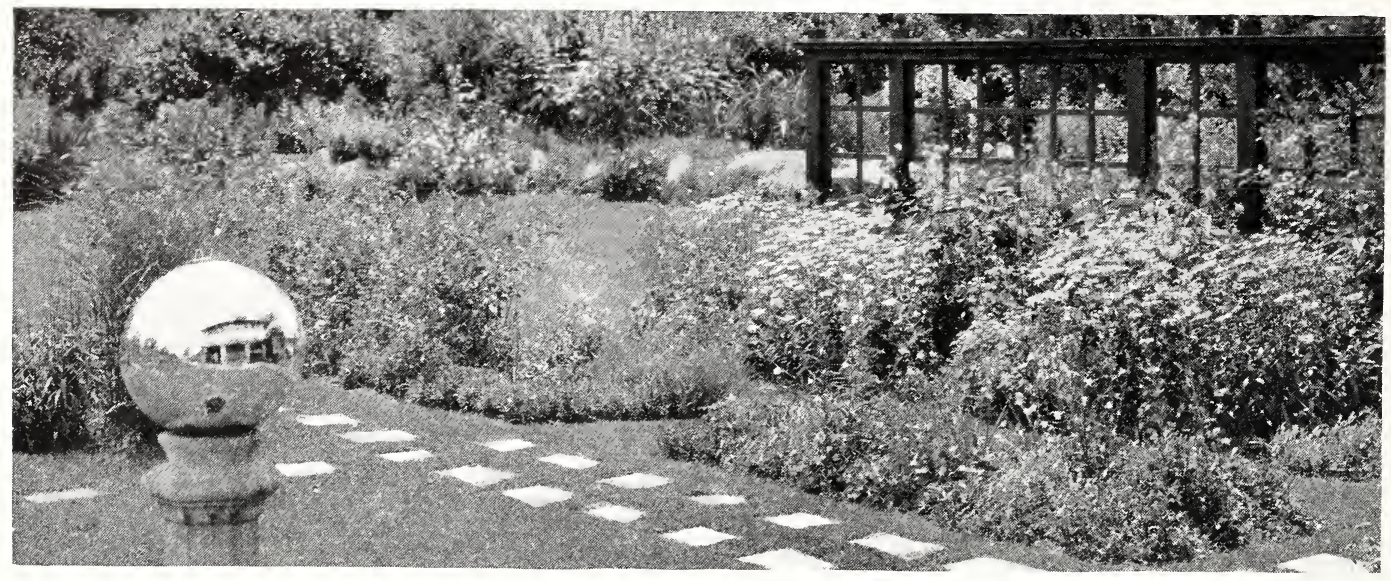

A WELL FURNISHED OUT-DOOR LIVING ROOM

\section{Beautify Your Home With Choice Flowers}

We specialize in flower seeds and list only varieties which have been tried and proven successful in our section of the country. A home can hardly be called a home without some bright colored flowers blooming in the yard, and adding cheer to the surroundings. Flowers, when care is exercised and common sense is used, are not hard to grow, and every home, every farm and every park should abound in them, and the school yards should be a source of pride and beauty.

Plant shrubs but don't plant all shrubs and no flowers as so many do, as you need bright flowers for a contrast in color.

One thing should be borne in mind, flower seeds should never be planted in a cold, wet ground, as they are delicate and will not readily germinate in adverse weather conditions. They should never be planted deep and the ground should be thoroughly prepared. A little care and attention will work wonders in a flower garden.

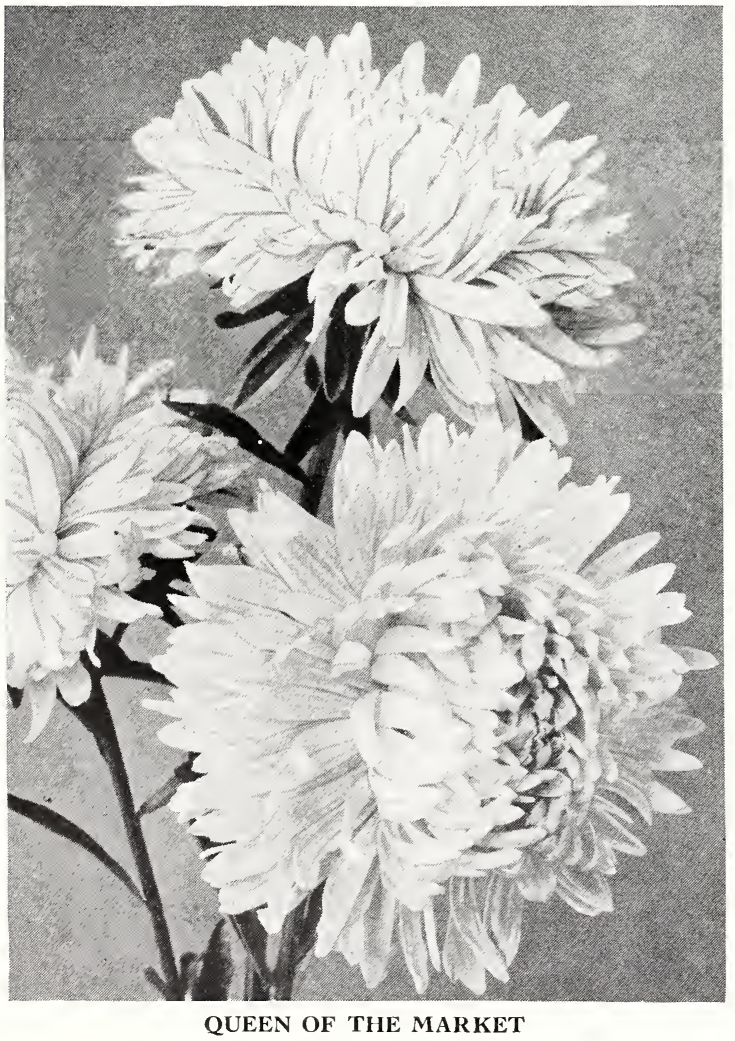

AMARANTHUS (Çaudatus).

Love-Lies-Bleeding. Long drooping racemes of deep red flowers. Pkt. 5c, oz. 25c.

ASTER (American Branching). This beautiful and popular class of hardy annuals stands unrivaled as Autumn-blooming plants.

Red

Pink

White

Lavender

Shell Pink

Blue

All Color Mixed. Pkt. 5c, oz. \$1.50.

Yellow Aster. Pkt. 10c, oz. \$3.00.

Queen of the Market. The earliest flowering of all Asters; largely used for market, and also excellent for pots.

Mixed. Pkt. 5c, oz. \$1.25.

Victoria. A recurved variety, bearing very large and showy flowers.

Mixed. Pkt. 10c, oz. $\$ \mathbf{2 . 0 0}$.

AQUILEGIA (Columbine). A showy and interesting plant, commonly called Columbine; stands the frost well; hardy perennials.

Mixed. Best double varieties. Pkt. 10c, oz. $\$ 5.00$.

\section{ALYSSUM.}

Maritimum Sweet. Free flowering plants for beds and edging. Pkt. 5c, oz. 35c.

Little Gem or Carpet of Snow. Dwarf compact plants that are a solid mass of white from Spring to Fall. Pkt. 10c, oz. 40c. 


\section{Harvey's Beautiful Flowers for the Garden}

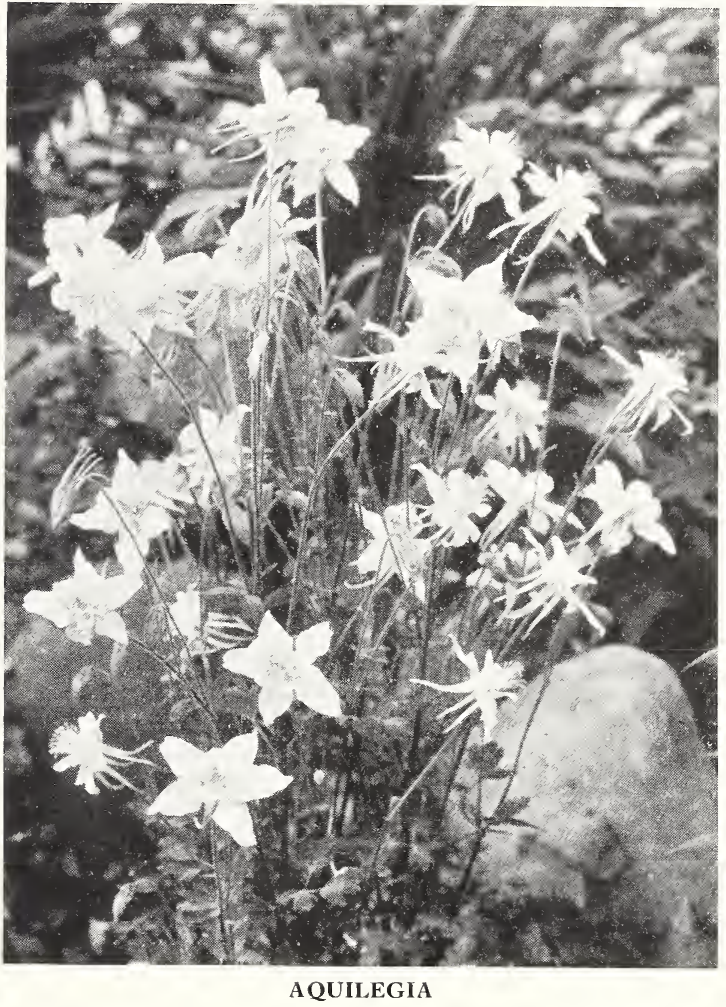

BACHELOR'S BUTTON (Centaurea Cyanus). Pretty flowers, in bloom all Summer, in shades of blue, pink and white mixed. Pkt. 5c, oz. 35c.

BALSAM (Lady' Slipper). A beautiful and popular class of plants. Tender annuals.

Camelia-flowered. Large double mixed. Pkt. 5c, oz. 50c.

CALENDULA. A coarse, free-flowering, showy class of annuals, the double varieties, very desirable.

Orange King. Bright orange, double. Pkt. 5c, oz. 30c.

Mixed. All colors, double. Pkt. 5c, oz. 30c.

Ball's Gold. Pkt. 20c, oz. \$1.75.

CALLIOPSIS. One of the best hardy annuals; colors rich; flowers numerous and beautiful.

Mixed. Double. Pkt. 5c, oz. 50c.

CANDYTUFT (Iberis). An old and universal favorite; almost indispensable for bouquets.

Carmine. Deep rose. Pkt. 10c, oz. 50c.

Empress. Pure white. Pkt. 10c, oz. 75c.

Lavender. Pkt. 10c, oz. 50c.

Flesh. Pkt. 10c, oz. 50c.

Mixed. All colors. Pkt. 5c, oz. 40c.

Hyacinth Flowered, Sweet Scented. Pkt. 10c, oz. $\$ 1.00$.

CARNATION. The most magnificent of all the Dianthus family; flowers large, beautiful and delightfully fragrant. Half hardy perennials.

Grenadine. Double mixed. Pkt. 10c, oz. \$2.75.

Marguerite. Unlike the ordinary Carnation, this variety blooms the first year; those sown in Spring commence flowering in latter part of Summer. They can be potted and taken into the house, and will flower abundantly throughout the Winter. Mixed colors. Pkt. 5c, oz. $\$ 2.00$.
CANTERBURY BELL (Campanula). This is one of the most useful and well known plants. Hardy perennials.

Double Mixed. Pkt. 10c, oz. $\$ 4.00$.

Single Red. Pkt. 10c, oz. \$1.20.

Single White. Pkt. 10c, oz. \$1.20.

Single Blue. Pkt. 10c, oz. \$1.20.

COCKSCOMB (Celosia). Beautiful, free flowering, graceful annuals, which for fine effect take the front rank in annual plants.

Mixed. All varities. Pkt. 5c, oz. $\$ 2.00$.

CHINESE WOOL FLOWER. Pkt. 10c, oz. \$3.00.

CENTAUREA. A hardy and showy class of bedding plants, including Bachelor's Button and Sweet Sultan. Candidissima, Dusty Miller. Silvery white, deep cut foliage. Pkt. 15c, oz. $\$ 4.00$.

Gymnocarpa. White foliage, delicately cut. Pkt. $15 \mathrm{c}, \mathrm{oz} . \$ 1.50$.

CALIFORNIA POPPY (Eschscholtzia). An exceedingly showy class of profuse flowering plants. Hardy annuals.

Mixed. All colors. Pkt. 5c, oz. 80c.

CHR YSANTHEMUM. The tall, double Chrysanthemums are among the most showy of Summer flowering plants.

Mixed. Perennial Double. Pkt. 5c, oz. 40c.

CASTOR-OIL PLANT (Ricinus). One of the most stately and ornamental large plants cultivated. Looks best grown as single specimens. Half hardy annual.

Zanzibariensis. A new African giant variety, surpassing all others in size and beauty. The leaf is sometimes two feet across, while the stem will reach a height of ten feet. Pkt. 5c, oz. 25c.

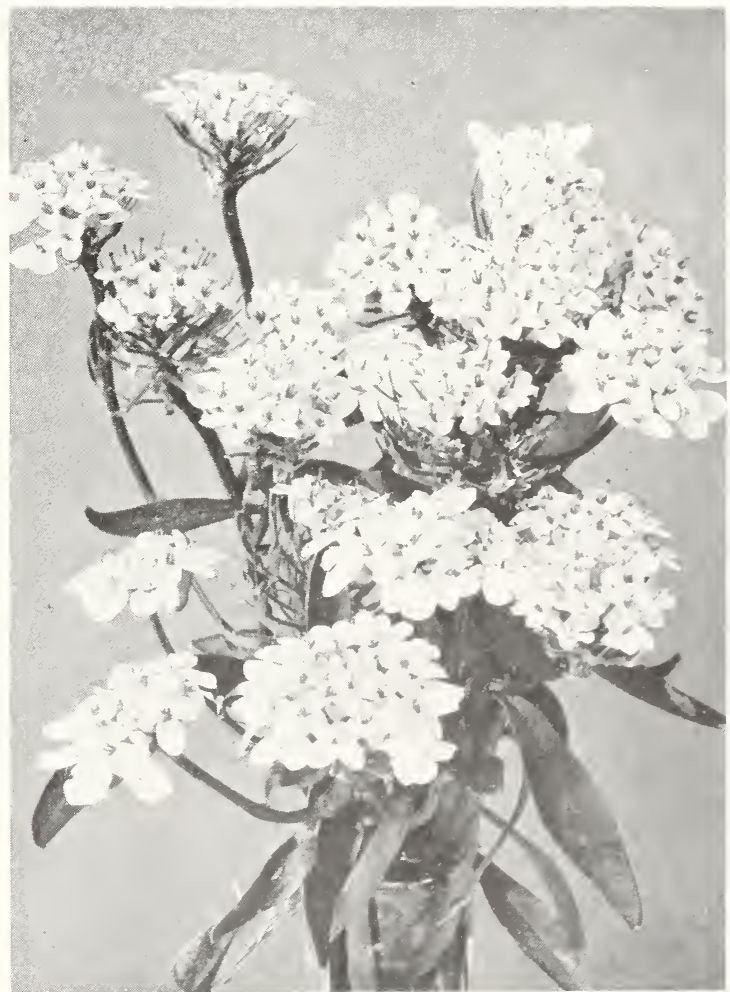

CANDYTUFT 


\section{Beautify Your Home With Choice Flowers}

\section{COREOPSIS.}

Lanceolata Grandiflora. Perennial. Single rich golden yellow flowers that bloom the entire Summer and Autumn. Pkt. 5c, oz. 50c.

COSMOS. One of our most beautiful Autumn flowering plants, growing to a height of four or five feet, and giving an abundance of blossoms after all others are done.

Single Crimson. Pkt. 10c, oz. 60c.

White. Pkt. 10c, oz. 60c.

Pink. Pkt. 10c, oz. 60c.

All Colors Mixed. Pkt. 5c, oz. 40c.

Double Crested Cosmos. Mixed colors. Pkt. 15c, oz. \$3.50.

DELPHINIUM. Perennial mixed, Hollyhock strain. Pkt. 25c, oz. $\$ 10.00$.

DOUBLE DAISY (Bellis). Pretty little well known border flowers; a cold frame in Winter and north border in Summer will insure plenty of plants.

Bellis Perennis, fl. pl. Choice mixed, double. Pkt. 10c, oz. \$3.00.

DATURA (Trumpet Flower). Half hardy annuals, producing large trumpet shaped flowers seven to nine inches long. Roots may be preserved during the Winter in sand in a dry cellar.

Fine Mixed. All colors. Pkt. 5c, oz. 75c.

EVERLASTING FLOWER (Helichrysum). An exceedingly handsome class, and of the greatest value for Winter bouquets; the flowers should be cut before they are fully expanded. Pkt. 5c, oz. 60c.

FORGET-ME-NOT (Myosotis). A charming and interesting perennial of easy culture, growing freely in any moist situation.

Victoria. Dwarf variety with very large flowers. Mixed. Pkt. 10c, oz. \$2.25.

Blue. Pkt. 10c, oz. \$2.50.

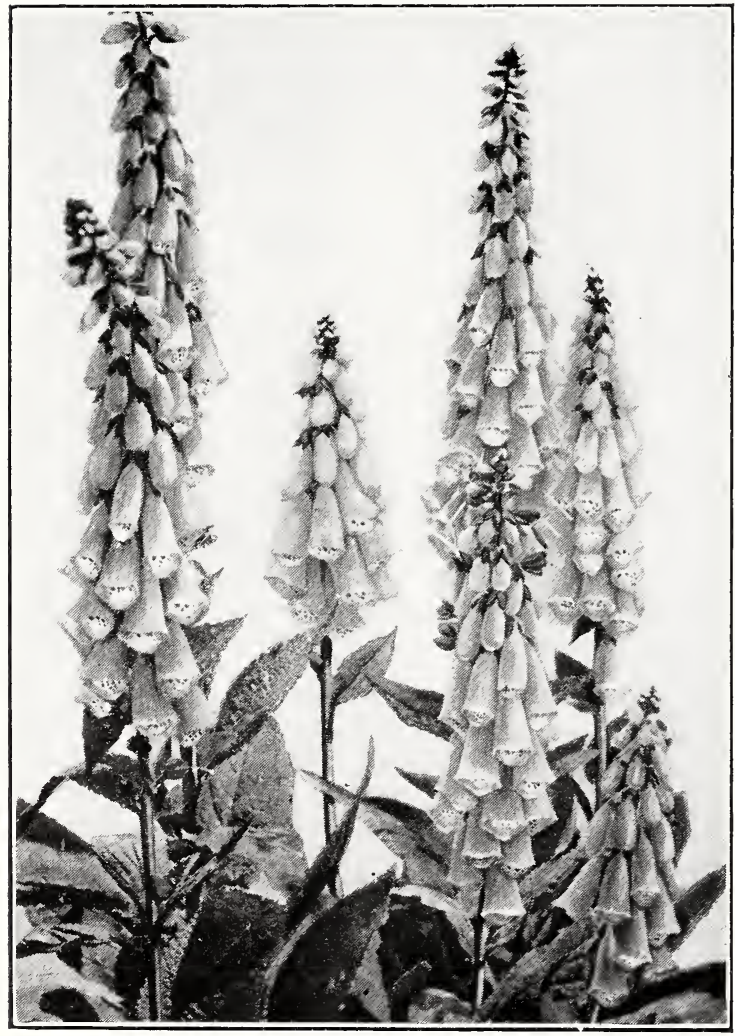

FOXGLOVE

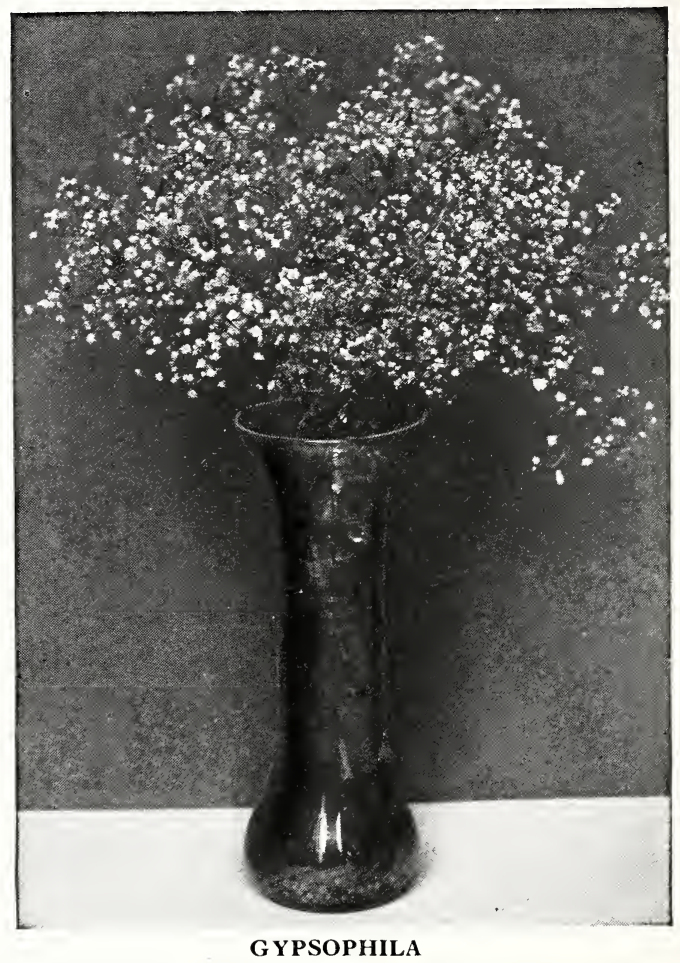

FOUR O'CLOCK (Mirabilis). The old and well known Marvel of Peru; a beautiful plant of fine habit, glossy foliage and fragrant flowers. Hardy annual.

Mirabilis Jalapa. Best mixed. Pkt. 5c, oz. 25c.

FOX GLOVE (Digitalis). Very effective and showy plants with dense spikes of flowers on stems three or four feet high. Hardy perennials.

Fine Mixed. All good varieties. Pkt. 5c, oz. 75c.

DIDISCUS COERULEUS (Blue Lace Flower). Pkt. $10 \mathrm{c}$, oz. $\$ 3.00$.

ESCHSCHOLTZIA (California Poppy)

Mixed Colors. Pkt. 5c, oz. 50c.

FLAX (Linum). A handsome variety of free flowering annuals, deserving a place in every garden.

Grandiflorum Rubrum. Crimson. Pkt. 5c, oz. 25c.

GAILLARDIA. A showy, vigorous class of constant bloomers, making a brilliant display.

Fine Mixed. Perennial. Pkt. 5c, oz. 80c.

Annual Mixed. Pkt. 5c, oz. 60c

GODETIA. A genus of exceedingly handsome and showy hardy annuals from California, growing about a foot and a half high, and producing numberless rosy-lilac flowers.

Dwarf Mixed. Pkt. 10c, oz. \$1.75.

GOURDS. A highly interesting class of ornamental climbing plants, with fruit of singular shape, color and markings.

All Kinds Mixed. Pkt. 5c, oz. 25c.

GYPSOPHILA (Baby's Breath). Excellent for cutting and putting in bouquets.

Alba. White. (Covent Garden Strain). Pkt. 5c, oz. 25c.

Rosea. Pink. Pkt. 5c, oz. 35c.

Perennial. Pkt. 10c, oz. 80c.

HOLLYHOCK. This old garden flower has much improved of late, and is becoming a greater favorite every year. The flowers being large and stems erect, 


\section{Beautify Your Home with Choice Flowers-Continued}

the plants look best when grown at the back of a border. Hardy biennial.

Double Yellow. Pkt. 15c, oz. \$3.00.

Double White. Pkt. 15c, oz. $\$ 3.00$.

Double Pink. Pkt. 15c, oz. $\$ 3.00$.

Double Mixed. Pkt. 10c, oz. $\$ 1.00$.

Single Mixed. Pkt. 10c, oz. 65c.

HIBISCUS. A showy ornamental class of annuals. The flowers are large and of beautiful color.

Best Mixed. Pkt. 5c, oz. $\$ 1.50$.

HELIOTROPE. A generaī favorite for its delicious fragrance. Pkt. 10c, oz. $\$ 1.60$.

KOCHIA SCOPARIA (Burning Bush). Hardy annual. A quick grower and soon forms a beautiful cypresslike hedge. In the Fall the entire plant takes on a rich deep red hue. Pkt. 5c, oz. 30c.

LARKSPUR (Annual). Beautiful showy plants from one to three feet in height. Excellent for background. Double mixed. Pkt. 5c, oz. 50c.

LOVE IN A MIST (Nigella). A singular plant, known also as the devil in the bush, owing to the flower being partially concealed by the finely cut foliage. Hardy annual. Pkt. 5c, oz. 25c.

LOBELIA. A charming class of fine trailing plants; delicate blue and white flowers.

Mixed. Pkt. 10c, oz. $\$ 1.75$.

LUPINE. Produces long spikes of pea-shaped flowers. Useful for mixed borders and cutting. Very popular. Hartwegi. Annual. Pkt. 10c, oz. 40c.

Polphyllus. Mixed. Perennial. Pkt. 20c, oz. 85c.

MARIGOLD (Tagetes). One of the universal favorites; the only element they lack of being a perfect flower being the odor.

African. Double mixed colors, tall. Pkt. 5c, oz. 40c. French. Double mixed colors, dwarf. Pkt. 5c, oz. 40c.

MIGNONETTE (Reseda). One of the most universal favorites in cultivation, because of its delicate fragrance.

Machet Sweet Scented. Pkt. 5c, oz. 30c.

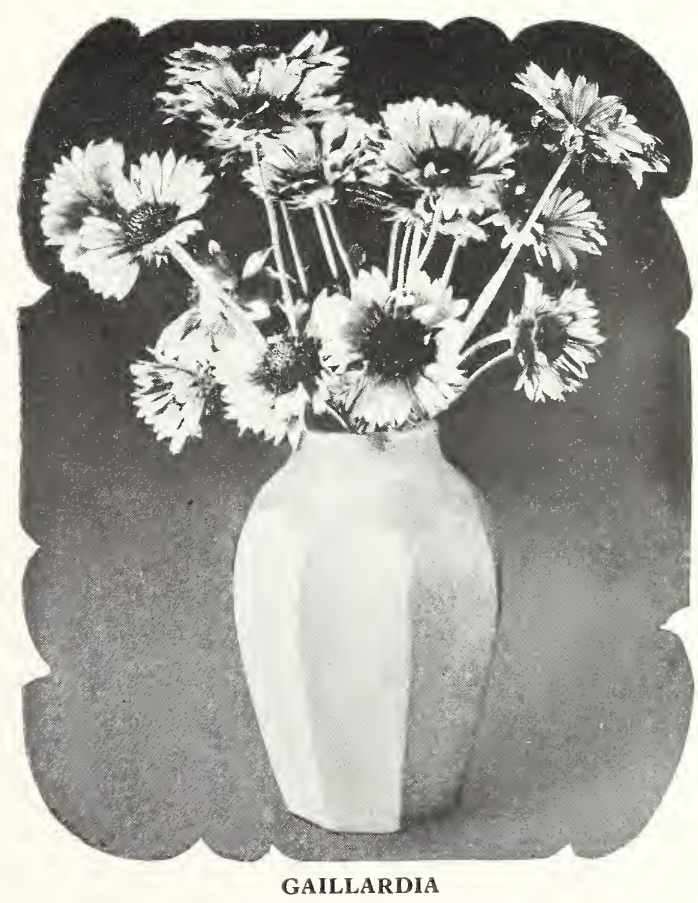

MOURNING BRIDE (Scabiosa). Very showy and pretty plants, excellent for mixed borders. Flowers of all colors from black to white. Very useful for bouquets. Hardy annuals.

Mixed. Dwarf varieties. Pkt. 5c, oz. 50c.

Rose, Scarlet, Blue. Pkt. 10c, oz. 80c.

NICOTIANA. A good border plant, having long tubed white flowers, which open about six o'clock p. m. and emit a powerful and pleasant odor during the evening and night.

Nicotiana affinis. Pkt. 5c, oz. $\$ 1.00$.

NASTURTIUM DWARF.

All Colors Mixed. Oz. 10c, 1/4 Ib. 35c.

PANSY. Commonly called Heartsease. This universal favorite is so well known as to render any description superfluous.

World's Best. A superb mixture. Pkt. 25c, oz. $\$ 3.00$. Good Mixture. Pkt. 10c, oz. \$1.75.

PHYSALIS FRANCHETI (Chinese Lantern Plant). Pkt. 10c, oz. $\$ 1.00$.

PINK. Very closely related to the Carnation and Picotee, but more vigorous and hardy. Hardy perennial.

Chinese Pinks. Pkt. 5c, oz. 50c.

Rock Garden Pinks. Pkt. 15c, oz. $\$ 4.00$.

PETUNIA. A plant of easy, vigorous growth, producing flowers in great abundance all the season.

Rosy Morn. Pkt. 10c, oz. \$4.00.

Violet. Pkt. 10c, oz. \$5.50.

Striped and Blotched. Pkt. 10c, oz. $\$ 3.75$.

Mixed. Pkt. 5c, oz. \$1.50.

Balcony Type. Unsurpassed for window boxes.

Continuous blooms throughout the season.

Deep Blue. Pkt. 15c, oz. $\$ 10.00$.

White. Pkt. 15c, oz. $\$ 8.00$.

Pink. Pkt. 15c, oz. $\$ 8.00$.

Mixed. Pkt. 20c, oz. $\$ 9.00$.

Giant Fringed. Pkt. 40c.

Good Double Mixed. Pkt. 50c.

PHLOX DRUMMONDII. For variety, brilliancy of color, and constant show there is no flower that equals the Phlox. Half hardy annuals.

Mixed. All colors. Pkt. 5c, oz. \$1.50.

DECUSSATA.

Perennial Mixed. Pkt. 20c, oz. $\$ 2.00$.

POPPY (Papaver). Very showy, hardy plants, producing immense flowers of brilliant color; succeed well in any good garden soil.

Iceland. Pkt. 10c, oz. \$2.25.

Paeony-flowered. Double mixed. Pkt. 5c, oz. 30c.

Oriental. Hardy, scarlet. Pkt. 10c, oz. $\$ 3.00$.

New Shirley. The flowers of this new variety are unsurpassed for grace and beauty. Colors running from blush and white to rose and crimson, but no scarlet. Pkt. 5c, oz. 80c.

PORTULACA. Low growing, neat plants, producing a profusion of brilliant, richly colored flowers. Succeed best on dry, gravelly soil. Half hardy annuals. Single. Mixed. Pkt. 5c, oz. \$1.25.

Double Rose-flowered. Pkt. 10c, oz. \$5.00.

PYRETHRUM (Perennial). Single and double mixed. Pkt. 10c, oz. \$5.50.

STOCK. The Ten-week or annual Stock present nearly all the requisites of a perfect flowering plant; beautiful flowers, delightful fragrance, early flowering and abundance of flowers.

Large Flowering Dwarf. Mixed. Pkt. 5c, oz. $\$ 1.00$.

SALPIGLOSSIS. Beautiful annuals, with large, showy, richly colored flowers, having a velvety softness seldom seen on other flowers.

Mixed. Extra large flowered. Pkt. 5c, oz. \$1.75. 


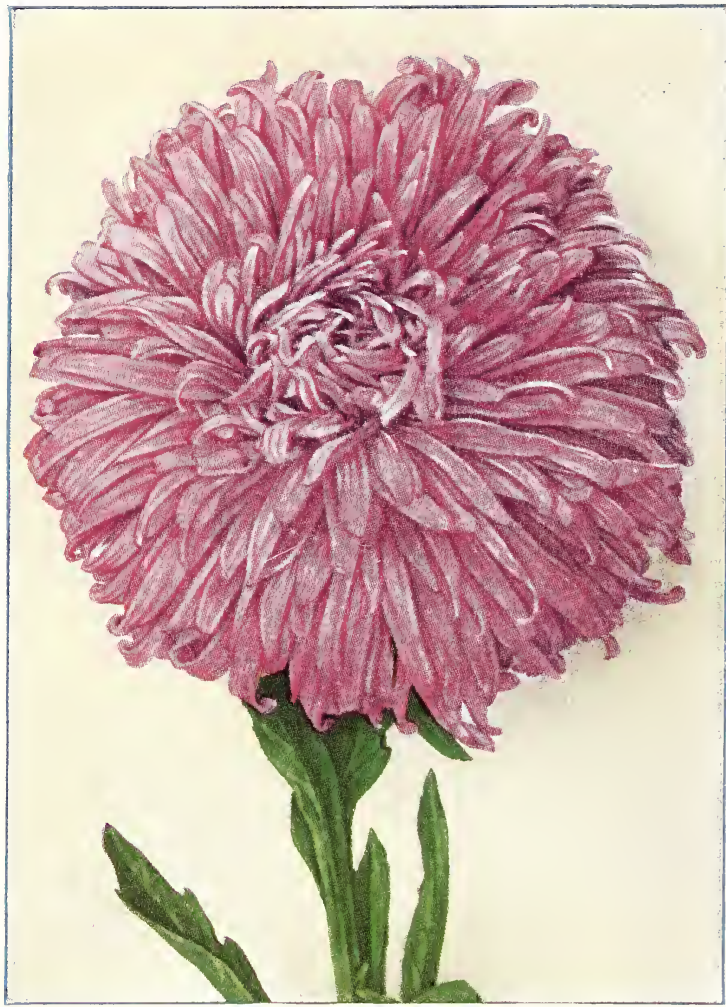

AMERICAN BRANCHING ASTER

\section{Flowering Plants}

SALVIA (Splendens).

Scarlet Sage. Bright richly colored flowers. Pkt. 10c, oz. $\$ 3.00$.

SNOW ON THE MOUNTAIN (Euphorbia). A very showy, hardy annual; one of our most useful foliage plants. Half hardy annual.

Euphorbia Variegata. Pkt. 10c, oz. 50c.

SNAP DRAGON (Antirrhinum). Fine and showy perennials, blooming freely the first Summer; continuing in bloom until frost.

Bonfire. Buff and orange. Pkt. 15c, oz. \$2.00.

Coral Rose. Coral. Pkt. 15c, oz. \$2.00.

Evening Sky. Salmon. Pkt. 15c, oz. \$2.00.

Golden King. Yellow. Pkt. 15c, oz. \$2.00.

Fire Brand. Scarlet. Pkt. 15c, oz. \$2.00.

Rose Queen. Rose. Pkt. 15c, oz. \$2.00.

Queen Victoria. White. Pkt. 15c, oz. $\$ 2.00$

All Colors Mixed. One-half dwarf. Pkt. 5c, oz. $\$ 1.00$.

SWEET WILLIAM (Dianthus Barbatus). Hardy perennials, one of our most desirable perennials, of various colors, mixed.

Double. Pkt. 5c, oz. \$1.00.

Salmon Pink. Pkt. 10c, oz. \$1.25.

Dark Crimson. Pkt. 10c, oz. \$1.25.

Single Mixed. Pkt. 5c, oz. $\$ 1.00$.

SUNFLOWER (Helianthus). Dwarf, double. Pkt. 15c, oz. 75c.

SCARLET RUNNER BEAN. A popular climbing plant with spikes of showy, scarlet flowers. Will bloom profusely all Summer. Oz. 10c.

TRITOMA (Red Hot Poker). Pkt. 10c, oz. \$5.00.

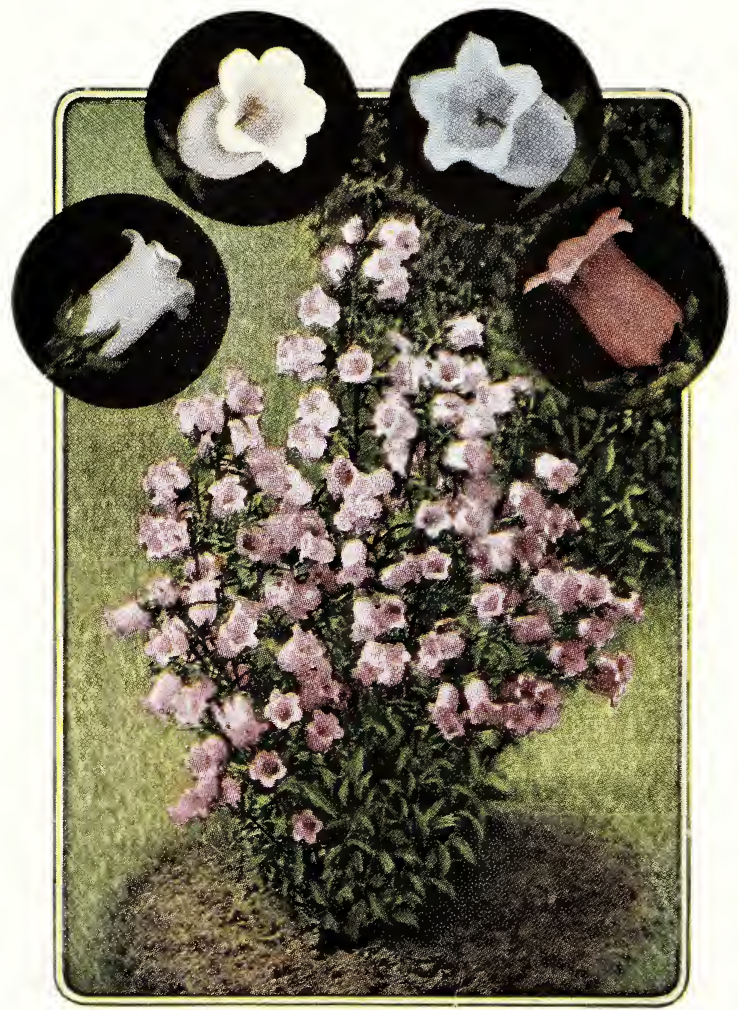

CANTERBUR Y BELLS

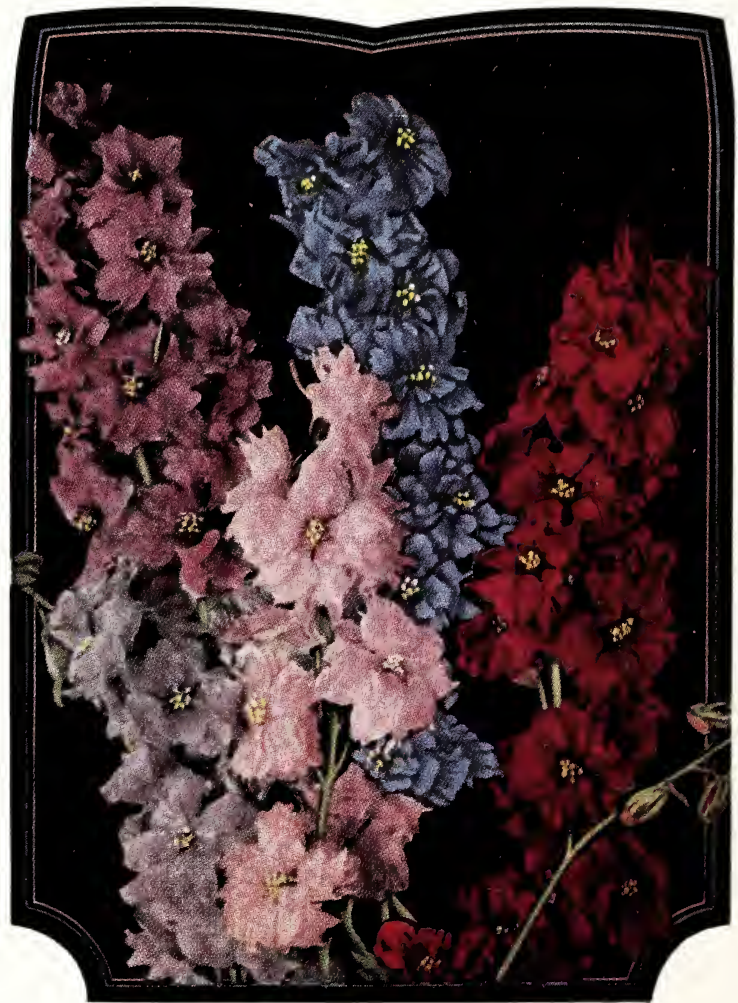

SNAPDRAGON 


\section{Flowering Plants}

VERBENA. A well known bedding plant, producing a profusion of flowers.

Mixed. All colors. Pkt. 5c, oz. \$1.00.

White. Pkt. 15c, oz. \$3.00.

Striped. Pkt. 15c, oz. $\$ 2.25$.

Pink and Rose. Pkt. 15c, oz. $\$ 2.00$.

Venosa. Purple. Excellent for rock work. Pkt. 10c, oz. \$3.00.

WALL FLOWER (Cheiranthus). Pretty little flowers, somewhat resembling Ten-week Stock. Pkt. 5c, oz. $\$ 1.00$.

\section{ZINNIA}

Gold Medal Dahlia Flowered.

One of the most brilliant and desirable annuals cultivated. Our stock is of the best.

Named Varieties. Each. Pkt. 10c, oz. \$2.00.

Crimson Monarch. Largest and best red flowers often 8 inches in diameter.

Oriole. The most beautiful of its class. Orange and gold.

Butter Cup. Yellow. Best in this shade.

Meteor. Very dark red. More floriferous than the other reds.

Purple Prince. Fine deep purple. Large and well formed.

Exquisite. Light rose with center a deep rose. By far the most pleasing of our collection.

Gold Medal Mixture. A mixture of the above varieties. Pkt. 10c, oz. $\$ 2.50$.

Special Collection of 6 Colors 50c.
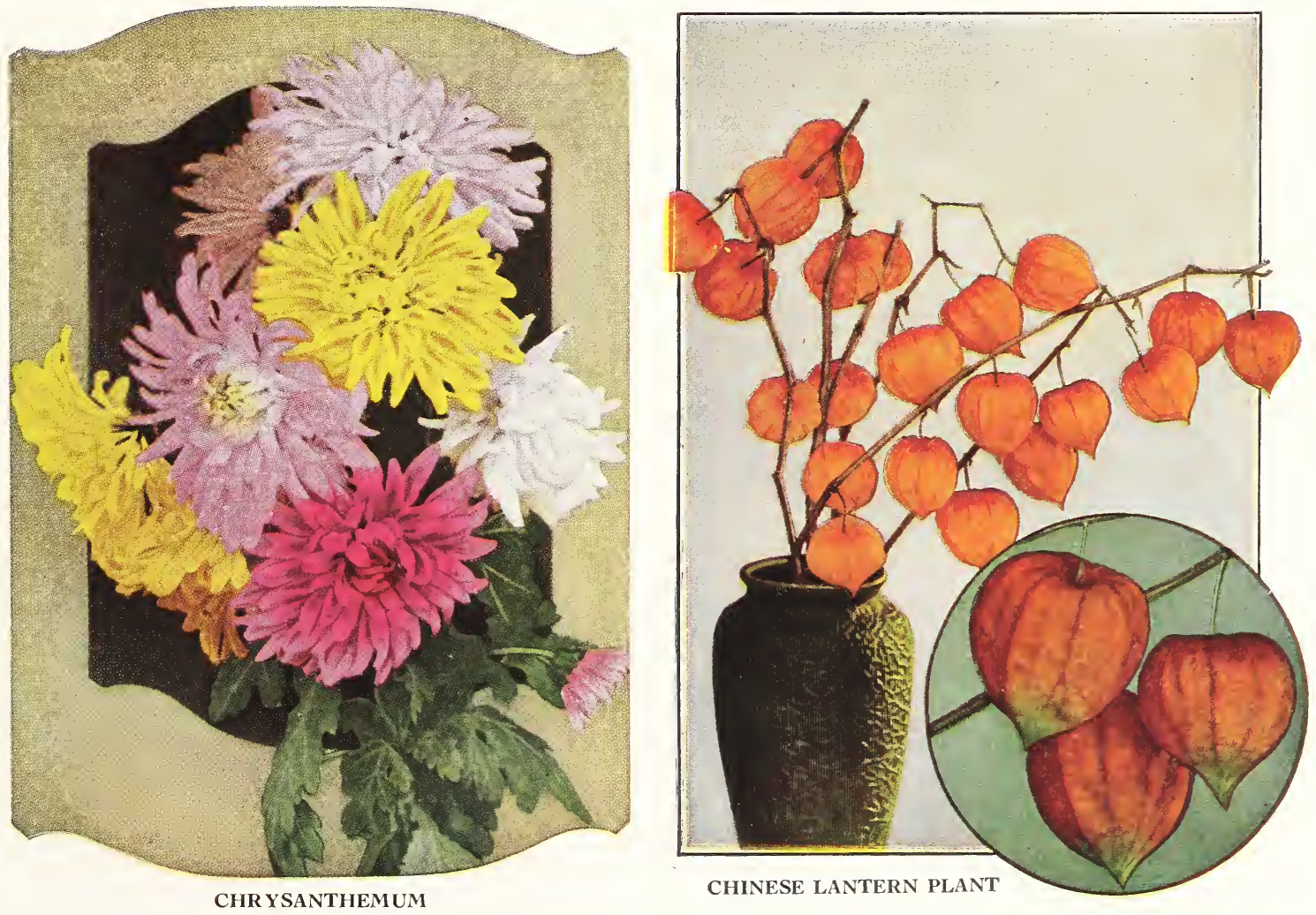


\section{Ornamental Climbers}

CYPRESS VINE (Ipomoea quamoclit). Graceful climber with dark green foliage and star-shaped flower. 7 ft. Pkt. 5c, oz. 50c.

GOURDS. Very useful in covering arbors, fences, etc., while the fruit is both ornamental and useful. 10 to $40 \mathrm{ft}$. Mixed. Pkt. 5c, oz. 25c.

HYACINTH BEAN (Dolichos). Quick growing ornamental climbers, producing clusters of white and purple pea-shaped flowers. Will thrive anywhere and make a dense shade. Mixed. Pkt. 5c, oz. 15c.

MOON FLOWER (Ipomoea). A rapid climber with immense white flowers from 5 to 6 inches in diameter. Blooms at night, hence its name. $20 \mathrm{ft}$. Pkt. 10c, oz. 80c.

THUNBERGIA (Black-eyed Susan). Beautiful climbers with an abundance of single flowers ranging in color from white to orange, with dark eye. Excellent for hanging baskets, vases, etc. When sown in beds, and pegged down like verbenas, will send up innumerable flower stalks, so as to make the whole bed a mass of flowers. $4 \mathrm{ft}$. Pkt. 5c, oz. $\$ 1.50$.

WILD CUCUMBER. One of the most rapid climbers we have for quickly covering verandas, trellises, etc., they are unequaled. After once started will seed themselves year after year. 10 to $15 \mathrm{ft}$. Pkt. 5c, oz. 20c.

SCARLET RUNNERS. A popular climbing plant with spikes of showy scarlet flowers. Continuous bloomer. 8 to $10 \mathrm{ft}$. Oz. 10c.

CARDINAL CLIMBER. A strong and rapidly climbing annual attaining a height of $30 \mathrm{ft}$. Fern like foliage covered with a blaze of fiery red flowers throughout the Summer and Fall. Pkt. 10c, oz. $\$ 2.25$.

CANAR Y BIRD VINE (Tropaeolum peregrinum). A very pretty vine with finely cut foliage and peculiar bright yellow flowers. It should be more universally planted than it is. Pkt. 10c, oz. \$1.75.
MORNING GLORY. Known everywhere, a new variety (Japanese Giant) although flowering somewhat later than the ordinary kind, is a royal acquisition with its immense and gorgeous colored flowers. Morning Glory. Mixed. Pkt. 5c, oz. 20c. Japanese. Mixed. Pkt. 5c, oz. 25c.

NASTURTIUM (Tall). This old time favorite has been improved by cross-breeding until its variations in coloring in both flowers and foliage are marvelously beautiful. There is no flower (excepting perhaps the Sweet Peas) which gives such large returns for so little care. It continues to bloom throughout the Summer till stopped by frost. Oz. 10c, 1/4 lb. 35c.

\section{SPENCER SWEET PEAS}

Spencer Sweet Peas are distinguished from other varieties by the enormous flowers with crinkled and wavy petals and also from the fact that they usually bear four blossoms on a stem.

Countess Spencer. Rose pink.

Dobbie's Cream. Deep primrose.

Etta Dyke. Pure white.

Fiery Cross. Bright red orange cerise.

Hawlmark Lavender. Clear light lavender.

Helen Lewis. Orange wings scarlet.

Othello. Deep maroon.

President. Dazzling orange scarlet.

Pkt. 10c, oz. 30c, $1 / 4$ lb. $\$ 1.00$.

Special Collection of 6 Colors 50c.

Spencer Superb Mixture. An extra fine mixture. Pkt. 15c, oz. 25c, $1 / 4$ lb. 85c.

Spencer Mixed. Pkt. 10c, oz. 20c, $1 / 4$ lb. 65c.

Eckford Select Mixed Sweet Peas. Oz. 10c, 1/4 lb. 25c, lb. 95c.

\section{Perennials and Rock Plants Suitable for Rock Garden Purposes}

Achillea Kelwayi Rosea (Yarrow). Flowers pink in dense heads. Will flower all Summer. Pkt. 15c, oz. \$4.00.

Anthemis Tinctoria Alba (Marguerite). One of the most satisfactory Summer flowering perennials, succeeding in poor soil. Grows bushy, 15 inches high, producing creamy-white flowers with yellow centers. Pkt. 10c, oz. \$2.00.

Arabis (Rock Cress). Hardy spreading tufts that are covered with a sheet of pure white flowers as soon as the snow disappears. Unequaled for rockeries and borders. Always neat. Height 6 to 9 inches. Pkt. 5c, oz. 50c.

Ârenaria Grandiflora (Sand Wort). A pretty, creeping plant which during June is covered with attractive white flowers. A good edging plant and invaluable for the rock garden. Pkt. 25c, oz. \$12.00.

Armeria Laucheana (Sea Pink or Thrift). Attractive dwarf plants that will succeed in any soil, forming evergreen tufts of bright green foliage, from which appear innumerable pink flowers in dense heads. Very useful in rockery or border as they flower more or less continuously from early Spring until late Fall. Pkt. 25c, oz. \$10.00.
Chelone (Penstemon) Barbata, New Hybrids (Turtle Head). Stately handsome plants that grow about two feet high and bear numerous spikes of large flower heads during Summer and Fall. Pkt. 10c, oz. 75c.

Crucianella Stylosa (Cross Wort). A low tufted plant with rose colored flowers that blooms during a greater part of the Summer. One of the best for the rock garden. Pkt. 20c, oz. $\$ 1.50$.

Helenium Hoopesii. Desirable border plants succeeding in any soil in a sunny location. Broad spreading heads of pure orange-yellow flowers covering a long blooming season. Useful for cutting. Pkt. 10c, oz. $\$ 1.00$.

Heuchera (Coral Bells). Dwarf, compact, bushy plants of robust constitution and easy culture growing $11 / 2$ to 2 feet high and bearing loose graceful spikes of flowers in the greatest profusion, during July and August. Excellent for rockery or border. Pkt. 25c.

Hypericum Polyphyllum (St. Johns Wort). Most desirable border plants of free and graceful habit, producing long, slender, much branched stems. Pkt. 25c, oz. \$12.00. 


\section{Rock Garden Plants-Continued}

Phystostegia Speciosa (False Dragon Head). One of the prettiest hardy perennials. It forms dense bushes 3 to 4 feet high, bearing freely during the Summer months, spikes of delicate tubular flowers not unlike a gigantic heather. Pkt. 20c, oz. \$4.00.

Salvia Grandiflora Azurea. Grows 3 to 4 feet high, producing during August and September, racemes of pretty sky-blue flowers in the greatest profusion. Pkt. 20c, oz. \$4.50.

Salvia Nemorosa Alba (Meadow Sage). Makes a shapely, bushy plant that blooms from July to late October. A white-flowered variety. Pkt. 20c, oz. $\$ 1.50$.

Saponaria Officinalis. Double white and rose. A useful plant for the rockery or border, producing masses of attractive flowers from May to August. Height 8 inches. Pkt. 25c, oz. $\$ 5.00$.

Veronica Spicata. An elegant hardy border plant, growing about $11 / 2$ feet high, producing long spikes of bright blue flowers in June and July. Pkt. 25c, oz. $\$ 4.00$.

\section{Collection of Annuals for Cut-Flowers}

Aster, Mxd. Brch.; Centaurea, Cyanus, Blue; Chrysanthemum, Annual; Cosmos, Giant Mixed; Gypsophila, Elegans White; Larkspur, Annual Mixed; Nigella, Miss Jekyll; Lupin, Annual Mixed Marigold, French Mixed; Poppy, Shirley Mixed; Calendula, Orange; Zinnia, Giant Mixed.

One Package Each of These 12 Splendid Varieties for $60 \mathrm{c}$

\section{BEDDING PLANTS ANNUALS}

Asters, Snapdragons, Zinnias, Verbena, Marigold, Petunias, Salvia, Scabiosa,

\section{PERENNIALS}

Sweet William, Pansies, Forget-Me-Not, Phlox,

Coreopsis, Gaillardia, Oriental Poppy, Shasta Daisy, Carnations.

\section{Bulbs for Spring Planting}

ANEMONES. Mixed. They provide color effects that are unsurpassable in intensity. Each 10c, doz. 85c.

Canna. The most satisfactory bedding plant we have. The dwarf French varieties are especially beautiful, bearing large flowers of most brilliant colors. Each $10 \mathrm{c}$, doz. $\$ 1.00$.

Eureka. Excellent foliage. Light green, flowers white with cream tinting. Height 4 to $41 / 2$ feet.

Hungaria. Bright rose-pink. Green foliage. Height 3 to $3 \frac{1}{2}$ feet.

King Humbert. Enormous flame scarlet flowers. Green foliage. Height 6 feet.

Louisiana. Vivid scarlet, orchid flowering type. Height 6 feet.

Yellow King Humbert. Large flowers of the most beautiful shades of yellow spotted red. Green foliage. Height 4 to 5 feet.
CINNAMON VINE. A beautiful, hardy climber, with glossy foliage and small sweet-scented flowers.

CALADIUM ESCULENTUM. Magnificent foliage plants sometimes called Elephant Ears. Leaves sometimes a yard long and half as wide. Size 9-11 inches. Each 10c, doz. \$1.00; 11-13 inches each 20 , doz. \$2.15; 13-15 inches each 30c, doz. \$3.25. Enormous Bulbs.

RANUNCULUS. Mixed. Resemble in form a miniature Dahlia but are as brilliant and varied in color as the Poppy. Each 10c, doz. \$1.00.

TUBEROSE. One of the most delightfully fragrant and beautiful flowering Summer bulbs. Our stock has never been flowered and will be sure to bloom. Excelsior Dwarf Pearl. Each 5c, doz. 45c.

MADEIRA VINE. Rapid climber, with glossy leaves and small white flowers. Each 7c, doz. 75c.

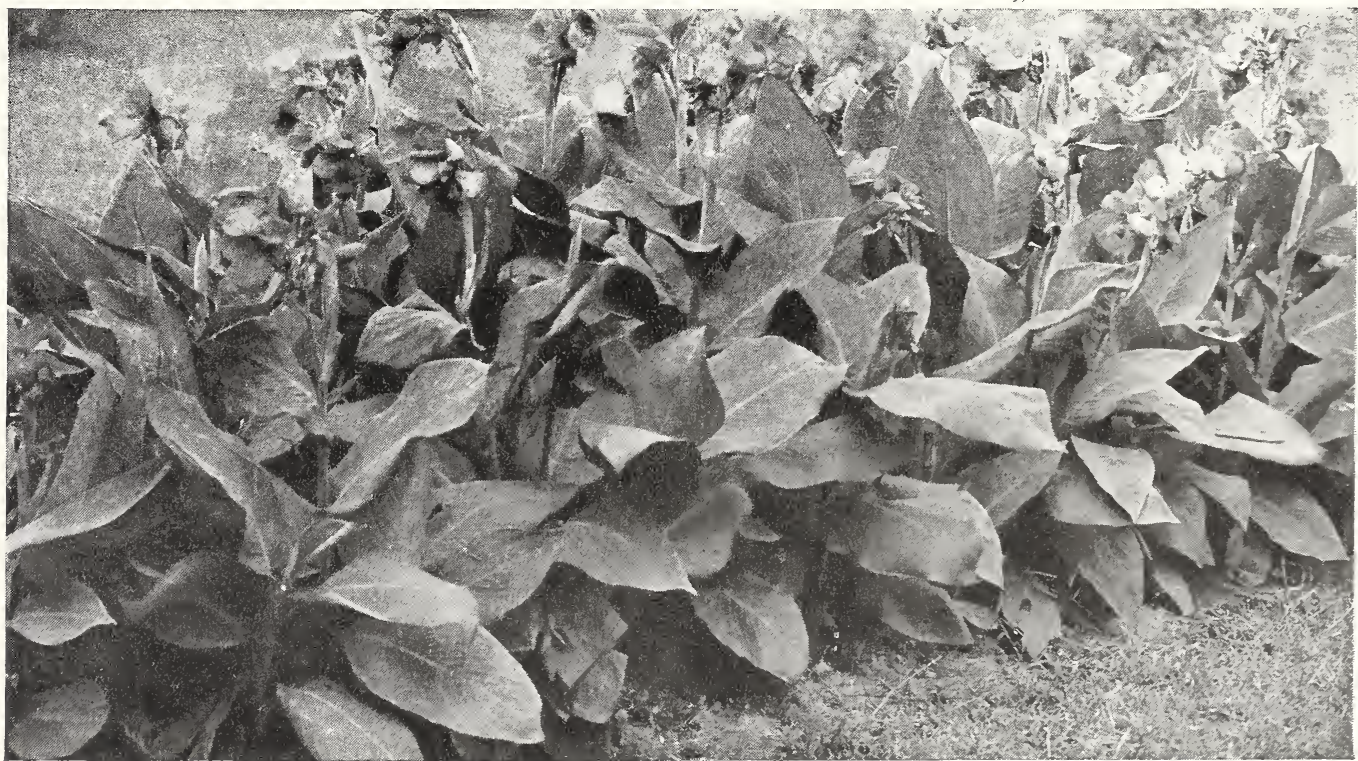

CANNAS 


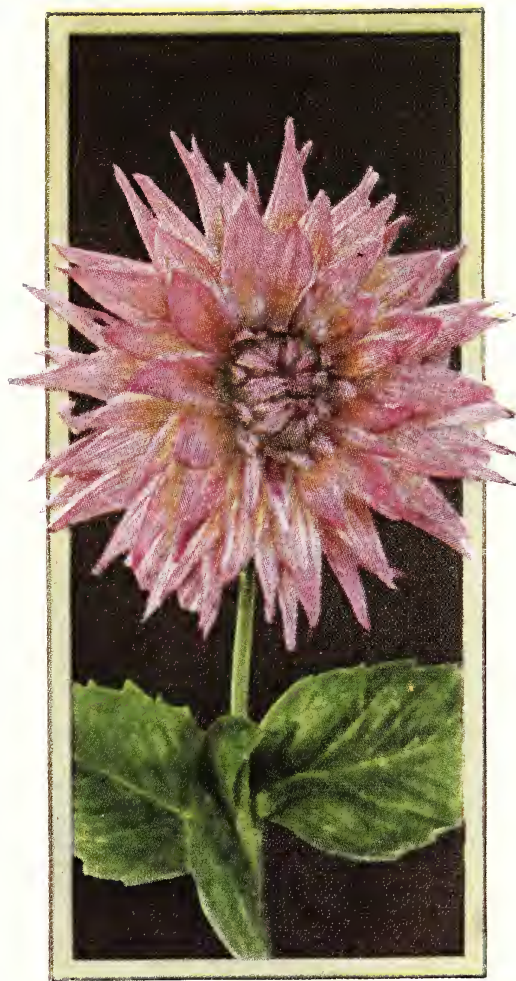

DAHLIA (CACTUS) Countess of Lonsdale

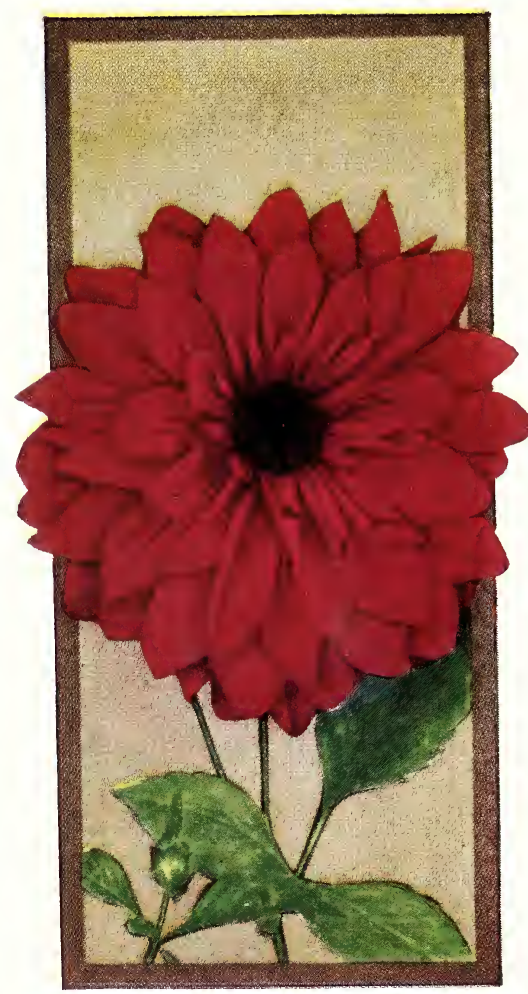

MINA BARGLE

\section{Bulbs for Spring Planting Dahlias}

The Most Choice Varieties

D-Decorative, C-Cactus, P-Peony type

Jersey Beauty-D. True pink, large size, the most popular Dahlia. Each 75c.

Mrs. Ide Ver Warner-D. Mauve pink, large. Each 50c.

Amun Ra-D. Shades of burnt orange. Each 50c.

Snowdrift-D. White, large size. Each 50c.

Mrs. John T. Scheepers-D. Light yellow, tinged pink on outer petals large. Each 50c.

El Dorado-D. Gold, large free bloomer. Each 75c.

Mina Bargle-D. Bright scarlet, large. Each 35c.

The Grizzley-D. Dark velvety-red, very large. Each 50c.

Sanhican's Bluebird-D. Violet-blue, large. Each 75c.

Judge Morean-D. Shades of salmon-gold and rosy peach red, large. Each 50c.

Nichu - C. Light yellow, large size. Each 75c.

Countess of Lonsdale C. Coral-rose, medium size, free bloomer. Each 35c.

Ballet Girl-C. Orange, tipped white, medium to large, very striking. Each 35c.

Rosalia Styles-P. Pink, large size, very artistic. Each 35c.

Jean Kerr-D. White, medium size, free bloomer. Each 35c.

Emperor-D. Violet-maroon, large size. Each 50c.

Elinor Vanderveer-D. Rose pink, large. Each 75c.

Common Varieties. Each 15c, 2 for $25 c$.

All of the above varieties of Dahlias are very popular, free blooming, some exceptionally so, and vigorous growers.

\section{Gladiolus}

Beautiful new varieties that rival the rose in beauty, they can be grown everywhere with but little care. Can be planted from last of April till middle of June.

Mrs. F. C. Peters. Fine lilac pink with purple blotch in throat. Very vigorous grower. Each 7c, doz. 75 c.

Jacoba Van Beyeren. Pure deep violet. Tall erect stem, highly recommended. Each 8c, doz. $80 \mathrm{c}$.

Bengal Tiger. Peculiar dull-red with dusky, bluish-gray stripes, a very striking variety. Each $\mathbf{8 c}$, doz. $80 \mathrm{c}$.

Scarlet Wonder. Purest deep scarlet, mammoth flowers, a real giant. Each 8c, doz. 80c.

E. Kirtland. Beautiful shade of rosy-pink fading to shell pink at the center with brilliant scarlet blotches on lower petals. Each 5c, doz. 50c.

Golden Measure. Extra fine dark yellow. The best in this shade. Each 10c, doz. 90c.

Mary Pickford. An extraordinary flower and spike of the most delicate creamy white, throat finest soft sulphur yellow. Each 5c, doz. 45c.

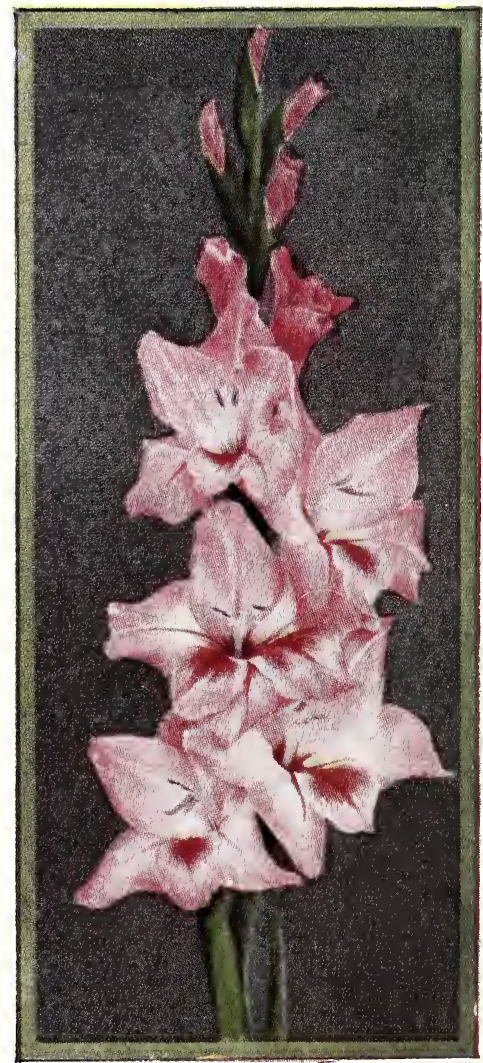

MRS. FRANK PENDLETON 


\section{GLADIOLUS - Continued}

Mrs. Frank Pendleton. Very large well expanded flowers of a lovely salmon pink, with deep red blotches in the throat. Each 5c, doz. 40c.

Crimson Glow. Glowing velvety crimson deeper in the center. Tall strong grower, considered the best in its color. Each 5c, doz. 40c.

Schwaben. Light yellow with little red stripes on lower petals. Strong grower with large flowers and sturdy stem. An old favorite with florists. Each $5 \mathrm{c}$, doz. 50c.

Mrs. Dr. Norton. Silvery white base tinged with pink, deepening toward edges of the petals, creamy blotches in throat on lower petals. Splendid cut flower. Each 7c, doz. 70c.

Odin. Deep salmon pink with intense carmine blotch on lower petals, very early, splendid cut flower. Each 6c, doz. 60c.

Carmen Sylva. Snow white, large flowers, extra fine cut flower variety. Each 6c, doz. 65c.

Jack London. Light salmon with vermilion stripes, canary yellow throat. A robust grower. Each 6c, doz. $60 \mathrm{c}$.

Mrs. Leon Douglas. Begonia rose striped with flame scarlet. Lower petal pale lemon speckled ruby. Extra large flowers. One of the largest glads in existence. Each 6c, doz. 65c

Alice Tiplady. Bright saffron orange, large open flowers on strong stiff stem. Excellent cut flower. Each 4c, doz. 35c.

Purple Glory. Deepest velvety maroon with almost black blotches. Large ruffled flowers. A real giant. Each 10c, doz. $\$ 1.00$.

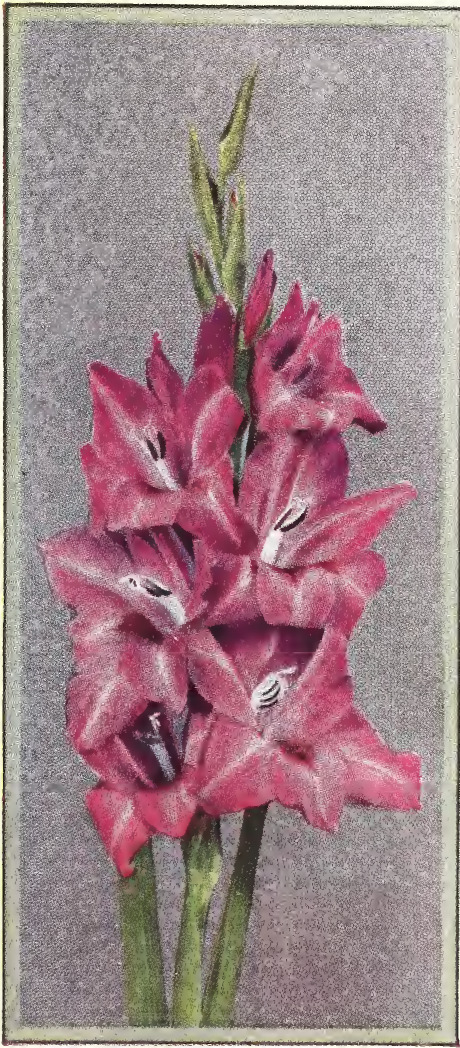

ODIN $30 \mathrm{c}$, doz. $\$ 3.25$.

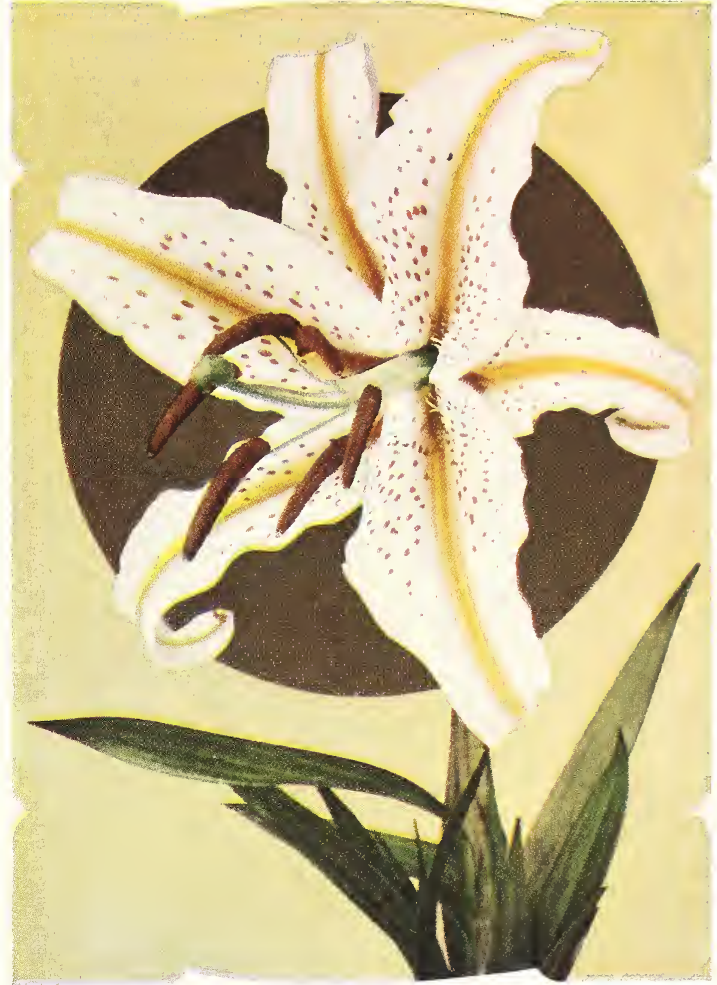

GOLD BAND LILY (Lilium Auratum)

Giant Nymph. Light rose pink, with creamy yellow throat. Very large well open flowers. Grows 6 feet tall. Each 5c, doz. 50c.

Los Angeles. Beautiful shrimp pink with glowing orange carmine blotch in throat. One of the best forcing varieties. Most bulbs blooming with two spikes. Each $5 \mathrm{c}$, doz. $50 \mathrm{c}$.

All Colors Mixed. A very superior mixture of the better varieties. Doz. 35c, $\$ 2.50$ per 100 .

\section{Lilies}

LILIES. Anyone can grow them; they should be set where they are to remain, as they do not take kindly to removal, and will grow larger and stronger from year to year if left undisturbed.

Auratum. The beautiful golden banded Lily of Japan; freely spotted with crimson and gold band running through the center of each petal; sweet-scented. Each 25c, doz. $\$ 2.75$.

Rubrum. White and rose, with crimson spots; sweet-scented. Each

Lilium Magnificum. Magnificent large flowers, ivory white, suffused rosy-crimson. Each 30c, doz. \$3.25.

Lilium Regale. One of the most beautiful Lilies yet introduced grows 3 to $5 \mathrm{ft}$. high and blooms in July. Large trumpet shaped flowers. Ivory white, shaded pink, tinged with canary yellow at the base of the petals. Perfectly hardy. Each 50c, doz. \$5.00.

\section{Begonias-Tuberous Rooted SINGLE}

Orange, Red, Yellow, Pink .............Each 25c, doz. $\$ 2.75$.

\section{DOUBLE}

Salmon, Rose, Scarlet, Orange ............ Each 25c, doz. \$2.75. 


\section{Harvey's Field Seeds}

\section{MARQUIS WHEAT \\ Holds the Championship Trophy for
The World's Best Wheat}

THE KING OF THE SPRING WHEATS

Even the name Marquis carries a conviction that inspires confidence, so enviable is the reputation it has attained as the earliest, largest yielding, most dependable, greatest adaptability and most plump of the bald Spring wheats.

Marquis is a cross between Calcutta, Hard Red and Red Fife (a combination of earliness, yield and high quality) Kernels are a beautiful dark red, hard, large size, a tractive shape and color. Heads are exceptionally large, beardless and practically rust-proof. Straw medium in height and very stiff.

\section{BARLEY}

Six-Rowed. Oderbrucker.

Two-Rowed. Chevalier Type. For feeding purposes the two-rowed is superior to the six, yielding a third more of both straw and grain.

\section{BUCKWHEAT}

Japanese. A new and distinct variety; the kernels are at least twice as large as any other variety.

Silver Hull. Earlier than the common variety, and yields nearly double under the same conditions.

\section{See Note Below \\ FIELD CORN}

\section{Bags will be Charged Extra in which Corn and Farm Seeds are Shipped}

Pennsylvania Flint. The largest of the Flints, ears sometimes growing 15 inches long, of a reddish yellow color. Vigorous grower and large yielder.

Genesee Valley. Our famous eight-rowed yellow flint, with ears from 12 to 15 inches long, cannot be equaled; small cob, beautiful bright golden yellow grains. Ripening very early, and good yielder.

Early Sanford. An eight-rowed white flint, very desirable for either grain crop or ensilage purposes.

King Philip. Copper colored with long, slim ears. An old standard variety.

Longfellow. Extra long ears of bright yellow color; very attractive.

Smutnose. A good old-fashioned variety with tips of ears stained red.

Pedigree Leaming. Best Silo Corn to be had, and is used for that purpose more than any other variety. Our stock is one of the best.

Bloody Butcher. An extra early maturing variety extensively grown in the Northern States where the seasons are short. Ears 8 to 12 inches long with 12 to 16 rows of a reddish or flesh color kernels, maturing in 90 days.

Pride of the North. An early Dent variety introduced several years ago, and as popular today as ever. We have the genuine variety.

Early Butler Yellow Dent. A cross from Pride of the North, and somewhat earlier than that excellent variety. Probably no corn in cultivation will outshell it, 70 lbs. of ears having shelled out $641 / 2$ lbs. of shelled corn. It has a beautiful yellow color, and will give the grower the grestest satisfaction.

White Cap Yellow Dent. Claimed to be 10 days earlier than the Leaming; and on poor, thin soil to outyield that variety by 25 per cent. The tip end of the grain is white and the inside yellow, which combination gives it a most beautiful appearance. Expert corn-growers pronounce it a perfect field corn.

Wisconsin White Dent. A new extra early variety, maturing ahead of our early frosts. Makes a good silo corn.

Iowa Gold Mine. A very deep-grained variety of a bright golden yellow; small cob, shelling out large quantities of corn.

Red Cob Ensilage. A large white corn with red cob; stalks especially sweet, tender and juicy; has short joints, abundance of leaves and grows to a great height; a perfect ensilage corn.

Virginia Eureka.

Pa. Golden Beauty-Our name for Sweepstakes type.

Write for Prices on Seed Corn

Bags Extra On Beans, Peas, Grass Seed and Seed Grains.

\section{RYE}

Spring. Shorter straw than winter.

\section{HAIRY VETCH (Vicia-villossa)}

Winter Vetch has been found adapted to nearly all parts of the United States. In drought resistance it is perhaps the best of the Vetches. It will also stand severe cold, so that it is rarely frozen out in the northernmost States. This makes it particularly valuable as a winter cover and green manure crop.

Hairy Vetch gives the best results when planted on well tilled and well drained land. Seed should be drilled or broadcasted at the rate of 25 to 40 pounds per acre. When grown for hay it is usually sown with a bushel of rye, oats or wheat. Some farmers, however, use only a peck or less of the grain. It may be sown from September to December. When desirable to delay the maturing of a fall-sown crop it may be pastured quite late in the Spring.

Winter Vetch. Lb. 20c.

Spring Vetch. Lb. 10c.

\section{SPELTZ}

A cereal somewhat resembling rye, yields enormous crops of green fodder if cut early, or may be left to ripen its grain, which is of great feeding value and relished by all kinds of stock.

\section{RAPE}

Dwarf Essex. Grown extensively for forage, especially for sheep. Sown in June or July, it yields a bounteous fall pasturage, on which sheep and young stock fatten with marvelous rapidity. If sown broadcast, about 5 lbs. per acre will be required; if drilled, considerably less will do. We have the true Essex Dwarf, which should not be confounded with the worthless annual. Lb. 12c.

\section{SUGAR CANE}

Early Amber. Used largely for fodder; rich in saccharine, and the best of dairy foods. Lb. 12c.

\section{COW PEAS}

Makes poor land rich and rich land better. For this purpose the Cow Pea is very popular, especially for light soil. There is no surer or cheaper method of improving worn-out soil than with Cow Peas. They add large quantities of nitrogen to the soil and leave it in good shape for the following crop. There are several varieties, and we carry the best adapted to the northern climates.

Whip-poor-will. The most popular.

New Era.

Due to rapidly changing prices we are unable to quote prices in this catalog-Write for price 


\section{Harvey's Farm Seeds}

\section{SOY BEANS}

$\begin{array}{ll}\text { Early Yellow Soy Beans } & \text { Hollybrook } \\ \text { Ito San } & \text { Mammoth Yellow } \\ \text { Manchu } & \text { Black Wilson }\end{array}$

Ask for prices on Cow Peas and Soy Beans.

\section{PEAS}

Canada Field. Per bu. $\$ 3.25$.

\section{MILLET}

Valuable as a catch crop. When grass is short may be sown up to the end of June or middle of July, and produce a good crop of hay.

German. $\$ 3.00$ per bu.

Broom Corn (or Hog). Valuable for hog and chicken feed. $\$ 3.00$ per bu.

Japanese. Comes from Japan; the largest variety of all; grows from 6 to 8 feet high, yielding immense quantities of feed. $\$ 2.25$ per bu. 32 lbs.

Hungarian Grass. Similar to the millets. $\$ 3.00$ per bu.

\section{ALFALFA, OR LUCERNE CLOVER}

There has been an erroneous impression that it could only be grown in certain favored localities; with proper treatment and the right seed, success is certain. The crop may be cut from 3 to 4 times a year, producing from a ton to a ton and a half at each cutting. By raising it the farmer not only produces large quantities of forage, but at the same time he is enriching his fields for future crops, as it is a great nitrogen gatherer. The matter of SEED is of the greatest importance, and we secure the best and purest samples obtainable.

Ask for prices.

Our experience with Bacteria for inoculation has been very successful and we heartily recommend it.

\section{OATS}

Scottish Chief Oats. A revelation in seed oats. Grains are brilliant, white, extra large. Weighs 42 to 46 pounds to the bushel. Grows about 4 feet high, with strong, stiff straw. Phenomenal yielders, often 75 bushels to acre. Northern grown and acclimated. Sow at least three bushels to acre.

White Wonder Oats. An excellent variety, of good weight.

Swedish. Very hardy and a sure cropper, large plump grain with thin hull.

\section{Ask for Prices on Field Seeds}

\section{SUDAN GRASS}

An annual grass, growing from 5 to 7 feet high in ten weeks, making enormous quantities of hay, eaten greedily by all kinds of stock, on which they will thrive. It will make two heavy cuttings in a season and grows freely in droughty weather. It should be sown broadcast at about 20 lbs. to the acre. Per lb. 15c.

\section{POTATOES}

Bovee. A new extra early variety, named after its originator, Mr. Martin Bovee of Michigan. It is a pink or flesh color of oblong shape. The Rural New Yorker says: "It seems that the Bovee is at least twelve days earlier than the Early Ohio and a very much better shape." The introducers claim that it is not only one of the earliest, but also a great yielder, and its cooking qualities cannot be excelled.

Early Ohio. Round early variety.

Early Six Weeks. Said to be a seedling from the Ohio, which it resembles, but very much earlier. Under favorable circumstances the potatoes reach the size of hens' eggs in six weeks from planting. Its extreme earliness makes it an ideal variety for the home garden. Ask for prices.

\section{Bags Extra On Beans, Peas, Grass Seed and Seed Grains.}

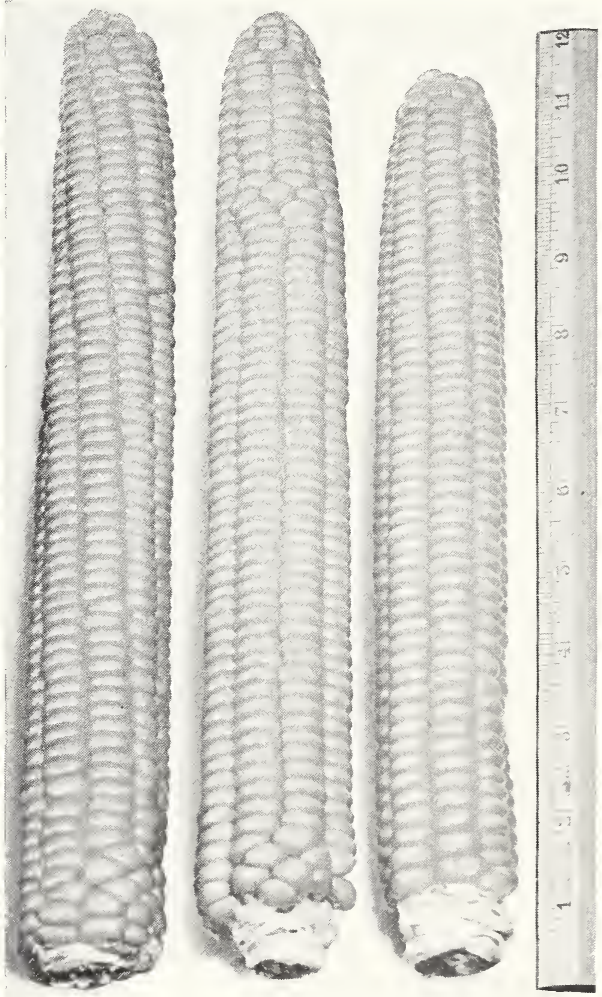

GENESEE VALLEY FLINT CORN

\section{COVER CROPS}

It is always wise to sow a cover crop on any land that is bare in the fall as early as September. These crops can be turned under in the spring and add much fertility to the soil, putting it in much better condition than if no cover crop was raised.

Hairy Vetch, alone or mixed with rye, is one of the best cover crops. Red clover is good if it can be sown early in August. 


\section{Harvey's Farm Seeds CLOVER AND GRASS SEED}

No seeds vary so much in quality or require more discrimination in buying. We exercise the greatest care in their selection, and offer only the best that can be procured, all carefully cleaned and free from noxious weeds. Special prices will be quoted on large quantities on application.

\section{CLOVER SEEDS}

Alsike. Native of Sweden, perfectly hardy, does not heave in Winter. Unsurpassed for bees. Price variable.

Medium Red. The common variety. Price variable.

Mammoth Red. Stock true and prime. Price variable.

Crimson. An annual with crimson flowers; valuable as a fertilizer; sown in late Summer after early crops are taken off, will produce a heavy growth to turn under the following Spring. Price variable.

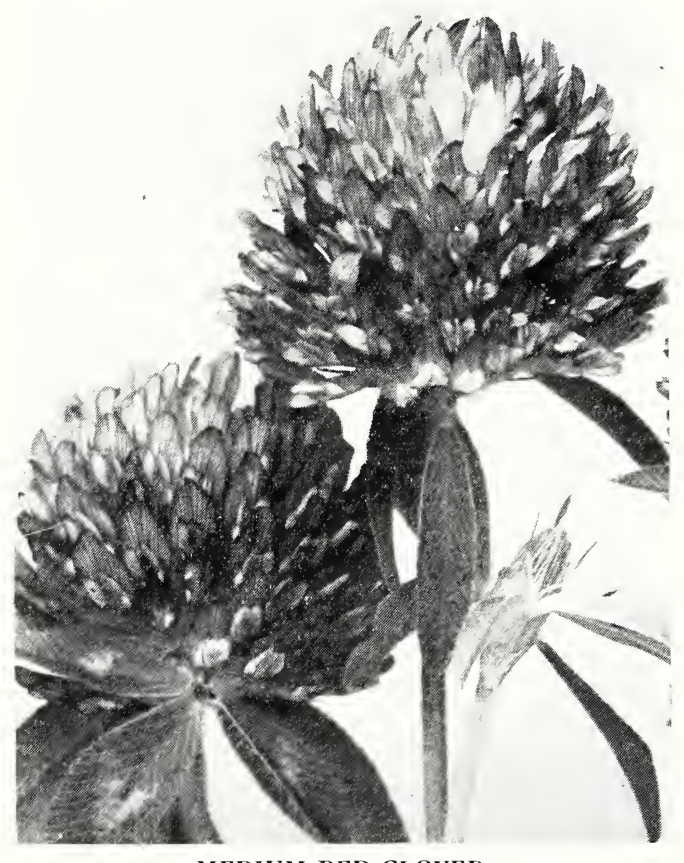

MEDIUM RED CLOVER

\section{GRASS SEEDS}

Red Top (Agrostis vulgaris). A valuable permanent grass as a mixture in either meadows, pastures or lawns. Cleaned from chaff. Lb. 40c.

Kentucky Blue Grass (Poa pratensis). Thrives on a variety of soils. Valuable for lawns. Lb. 40c.

Orchard Grass (Dactylis glomerata). The most valuable and widely known pasture grass. Lb. 35c.
German Bent. A creeping grass of great merit for shady places and slopes. Lb. $\$ 1.25$.

Colonial Bent Grass. Used for same purpose as German Bent Grass. Lb. \$1.00.

Crested Dog's Tail (Cynosurus cristatus). Forms a close turf; may be advantageously sown on lawns. Lb. 75 c.

White Dutch Clover. A dwarf clover for the lawn. Lb. 70c.

Canada Blue Grass. Lb. 40c.

Hard Fescue (Festuca duriscula). Thrives well in dry situations, where many other grasses would fail. Lb. 50c.

Rye Grass (Lolium prenne). The staple grass of Great Britain, entering largely in to the composition of many of the richest meadows and pastures. Lb. 30c, 100 lbs. $\$ 25.00$.

Meadow Fescue (Festuca pratensis). The most important species of the fescues; highly valuable for permanent grass lands, both for Spring and Autumn. Lb. 40c.

Wood Meadow (Poa nemoralis). Well adapted to shady situations; growing readily where others refuse to thrive. Lb. $\$ 1.00$.

Rough Stalked Meadow (Poa trivialis). Thrives best in moist, sheltered soils; well adapted for irrigated meadows and places shaded by trees. Lb. 80c.

Harvey's Special Pasture Mixture. A good pasture mixture should consist of permanent grasses mixed in proper proportions, to insure a luxuriant growth throughout the season. Our Special will meet the average need, and for all ordinary conditions will be found entirely satisfactory and make a bounteous supply of feed, where Timothy alone would prove an absolute failure. It should be sown at the rate of 30 lbs. per acre. 100 lbs. $\$ 35.00$.

We pay particular attention to the needs of golf courses and prepare special mixtures adapted to your soil conditions. We also prepare mixtures for formulas furnished by the clubs. Prices on application.

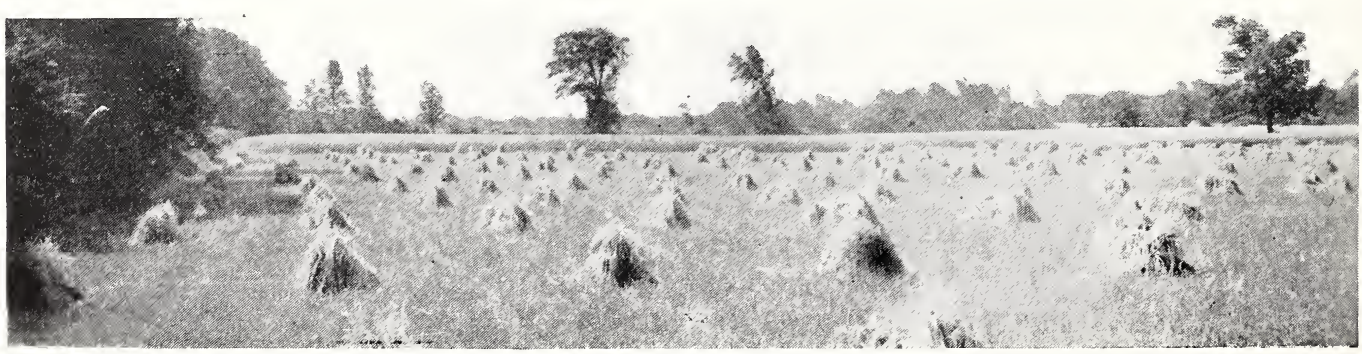




\section{Insecticides}

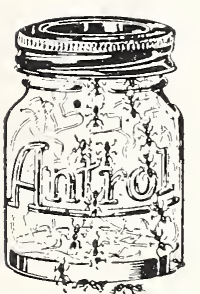

Antrol. A real ant control. Kills the entire colony not only the workers. Safe to use around children. Small set 95c.

Arsenate of Lead. Dry. $1 / 2$ lb. 20c, lb. $35 \mathrm{c}, 4$ lbs. $\$ 1.00,100 \mathrm{lbs}$. $\$ 21.00$.

Paris Green. Largely used for spraying trees, potatoes, etc. $1 / 4 \mathrm{lb} .20 \mathrm{c}, 1 / 2 \mathrm{lb}$. $30 \mathrm{c}, 1 \mathrm{~b} .50 \mathrm{c}$.

Cro-Tox. Stop the crows pulling your corn. $\mathbf{l}$ bu. size, $\$ 1.00,2$ bu. size $\$ 1.50$.

Slug Shot. A non-poisonous powder to be applied dry; particularly effective for potatoes. Lb. 25c, 5 lbs. 50c, 10 lbs. 95c.

Scalecide. Recommended for scale as a Winter spray. Dilute I gallon to 15 gals. of water. Gal. \$1.50, 5 gals. $\$ 6.75$.

Tree Tanglefoot. The best remedy against caterpillars and all tree-crawling insects. Will remain sticky for three months. Lb. 60 c, 5 lbs. $\$ 2.75,10$ lbs. $\$ 5.25,25$ lbs. $\$ 11.00$.

Tobacco Dust. Pure tobacco ground to a fine powder. Effective in the destruction of all insect life; especially useful on cucumbers and all tender plants, as it does not burn. Lb. 15c, 5 lbs. 60c, 10 lbs. $\$ 1.00$.

For blight, etc. Lb. 50c, 5 lb. pkg.
$\$ 1.75$, 10 lb. pkg. $\$ 3.00$.

Bordeaux Mixture. For black rot, mildew, etc. In powdered form. Per lb. box, 35c, 4 lbs. $\$ 1.00$, with Paris Green, 50c.

Dry Lime Sulphur. For scale insects on trees and shrubs, and such fungus bark diseases as can be treated in Winter. Dilute and apply with a spray pump while the trees are dormant and before the buds swell in Spring. It can be used strong during midWinter, but earlier or later dilute it $5 \mathrm{lbs}$. to 50 to 60 gals. of water. Price, $1 \mathrm{lb}$. can $30 \mathrm{c}, 5 \mathrm{lb}$. can $\$ 1.25$, 10 lb. can $\$ 2.35,25$ lbs. $\$ 3.75$.

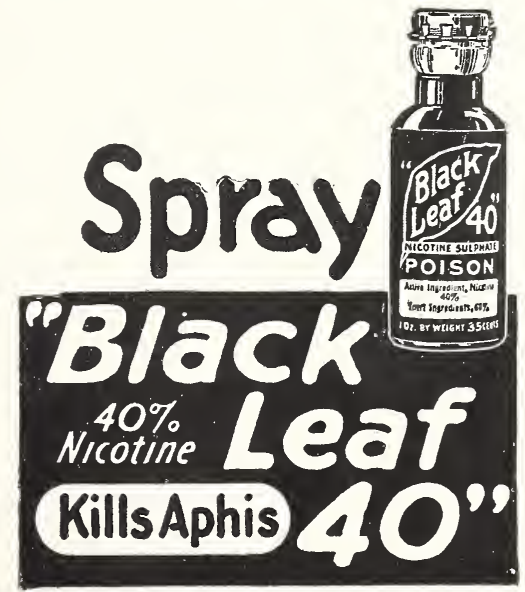

Delouse your entire flock of poultry by painting the roosts with Black Leaf 40. Easy to apply and very effective.

Black Leaf 40. A concentrated nicotine solution. Oz. $35 \mathrm{c}, 1 / 2$ lb. can $\$ 1.25,1$ lb. can $\$ 2.50,2 \mathrm{lb}$. can $\$ 3.75,5 \mathrm{lb}$. can $\$ 7.00,10 \mathrm{lb}$. can $\$ 11.85$.

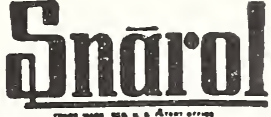

Snarol. For cut worms, slugs, snails, sow bugs, grass hoppers. Lb. 50c, 3 lbs. $\$ 1.00,15$ lbs. $\$ 3.75$.

The National Pest Control

Hammond's Weed Killer. Will kill all vegetation in walks, drives, etc. Qt.60c, gal. \$2.00.

Kalite. A non-poisonous dusting powder insecticide with certain fungicidal and soil sweetening qualities, already mixed ready to use. Recommended for use as a dust against most external leaf eating and chewing insects. This product is mailable. Lb. $35 \mathrm{c}, 5 \mathrm{lb}$. can $\$ 1.50,25 \mathrm{lb}$. can $\$ 5.00$. Postage extra.

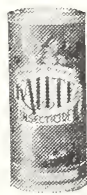

Derrisol. Sure death to plant lice on flowers, shrubs, trees and vegetables. Oz. 35c, $8-\mathrm{oz}$. bottle $\$ 1.20$, lb. can $\$ 2.00$.

\section{Inoculate \\ ALL LEGUMES \\ Alfalfa, All Clovers, Soy Beans, Cow Peas, Peas

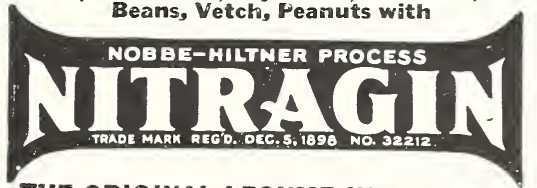 \\ THE ORIGINAL LEGUME INOCULATOR} Guarenteed Fresh Each Year Leads in High

For profitable results, Agricultural Colleges advise inoculation for all legume seed, because it pays well in producing larger quality yields. Fresh, high count NITRAGIN, containing billions of efficient nitroger. gathering germs, builds up the soil

gath Legume Germs a re PERISHABLE. To Protect You, NITRAGIN Cans are Stamped With Expiration You, NITRAGIN Cans are
Date. Insist on NITRAGIN.

\begin{tabular}{|c|c|}
\hline $\begin{array}{l}\text { Mixing Nitragin } \\
\text { with Seed }\end{array}$ & $\begin{array}{l}\text { between } 30 \%-40 \% \\
\text { moisture, will readily } \\
\text { stick to the seed with- } \\
\text { out adding water, and } \\
\text { give inoculation. How- } \\
\text { ever, for best results, } \\
\text { the preferred practice, } \\
\text { recommended by The } \\
\text { Nitragin Company and } \\
\text { Agricultural Authori- }\end{array}$ \\
\hline $\begin{array}{l}\text { ume germs die } \\
\text { idly when dried. } \\
\text { RAGIN, containing }\end{array}$ & $\begin{array}{l}\text { ties is to use water } \\
\text { when mixing legume } \\
\text { culture with seed. }\end{array}$ \\
\hline
\end{tabular}$$
\text { NITRAGIN, containing culture with seed. }
$$

\begin{tabular}{|c|c|}
\hline NITRA & $\mathrm{PR}$ \\
\hline Alfalfa, All Clovers & Peas, Vetch, Beans, \\
\hline Size Retail & Austrian Winter Peas \\
\hline $1 / 4$ bu.............\$ . 40 & Size \\
\hline $1 / 2$ bu.............. .60 & $1 / 2$ bu. \\
\hline 1 bu........... 1.00 & 1 bu......... \\
\hline 5 bu.......... 4.75 & $* 12 / 3$ bu........... \\
\hline $\begin{array}{c}\text { When ordering, always } \\
\text { specify kind of seed }\end{array}$ & bu...... called \\
\hline
\end{tabular}
Soy Beans and Cow Peas

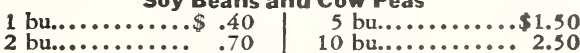

Garden Nitragin - Garden Size Peas, Beans, Sweet Peas

Inoculates from 1 ounce to $8 \mathrm{lbs}$. seed. Price $\$ .25$ IMPORTANT: When ordering NITRAGIN, I. ways be sure to state kind of legume seed you wish to inoculate.

Nitragin Has Served the American Farmer Since 1898 


\section{Insecticides-Continued}

\section{Ever Green will protect your garden-Guard its beauty from insects}

EVER GREEN kills chewing and sucking types of insects including the Japanese beetle. Nonpoisonous and pleasant to use, won't burn delicate blooms.

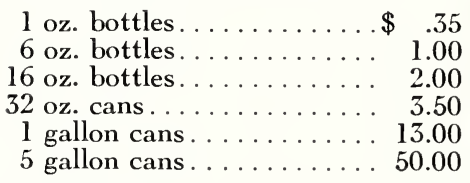

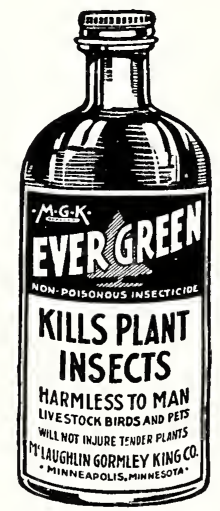

Pomogreen. A powdered insecticide and fungicide. Excellent for roses. Lb. 50c, 5 lbs. \$2.00.

Fungtrogen. For black spot on roses as well as some other diseases. Will not discolor leaves or blossoms. Small size 45c, 1/2 pt. $75 c$, pt. $\$ 1.25$.

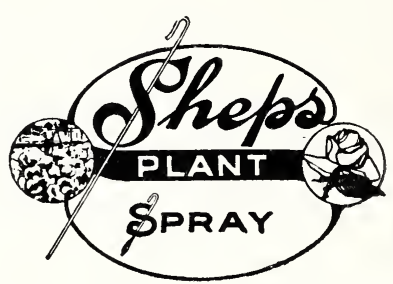

An excellent non-poisonous spray that kills chewing and sucking insects.

Quickly and easily prepared. All that is necessary is to mix Sheps Plant Spray with water in the correct proportion and you have a perfect spraying solution ready for use in just a few seconds. Guaranteed nonpoisonous.

2 oz. bottle $\$ \mathbf{. 3 5}$ makes 4 gals. spraying solution

$1 / 2$ pt. bottle $\quad .75$ makes 16 gals. spraying solution

Pint bottle 1.25 makes 32 gals. spraying solution

\section{Increase Your Farm Profits With Dubay Seed Disinfectants}

\section{Better Disease Control}

$$
\text { at Less Cost With }
$$

\section{New Improved SEMESAN BEL}

At least $50 \%$ of all seed potatoes planted in this country carry disease in some form or other. Even the use of certified seed does not insure against disease.

The new Improved Semesan Bel now offers an instantaneous dip treatment for potatoes that cost but $1 \frac{1}{2}$ to $3 \mathrm{c}$ a bushel, or less than the old "two hour" soak methods-protects seed from rotting in cold, wet soil-gives better control of seed-borne scab and Rhizoctonia-more consistent increases in yield and consequently larger profits. It is rapid and easily used. Just mix Improved Semesan Bel with water, dip your potatoes, drain and plant. No timeconsuming soaking necessary. One pound of Improved Semesan Bel treats from 70 to 80 bushels of seed potatoes.

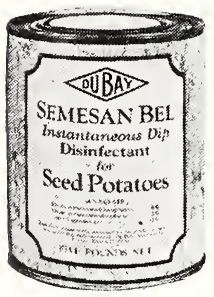

New Improved SEMESAN BEL PRICES

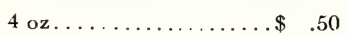

$1 \mathrm{lb} \ldots \ldots \ldots \ldots \ldots, \quad 1.75$

$5 \mathrm{lb} \ldots \ldots \ldots \ldots \ldots . . .6 .00$

$25 \mathrm{lb} \ldots \ldots \ldots \ldots \ldots \ldots .31 .25$

\section{SEMESAN}

A disinfectant for vegetable and flower seeds generally increases germination, preserves seed against rotting-increases yieldgenerally prevents and controls damping off.

PRICES

2 oz. tin......\$.50 l lb. tin ....\$2.75 5 lb. tin ....\$13.00

\section{Protect Your Grains from Smut Increase Your Crop Yields with CERESAN}

Why lose part of your grain crops through smuts and other seed borne diseases? Prevent these diseases and protect your profits by treating all seed grains with Ceresan before sowing. Effective in controlling stinking smut and seed-borne flag smut of wheat; seedling blight of cereals caused by seed-borne scab; smuts of oats; covered smut and stripe of barley; kernel smuts of sorghums and millets; and seed-borne stem smut of rye. Seed may be treated in spare time. Ceresan is harmless to seed and does not injure grain drills. Use $2 \mathrm{oz}$. per bushel of seed wheat, rye, sorghums or millets; $3 \mathrm{oz}$. for oats and barley.

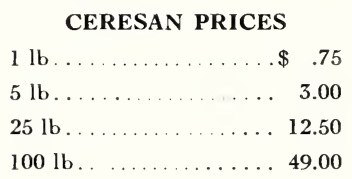

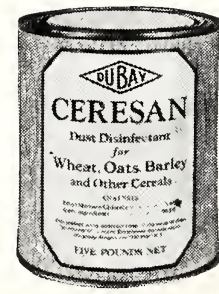

\section{SEMESAN, JR.}

Seed corn disinfection with Semesan Jr. is profitable crop protection. Early planting of corn frequently makes larger yields possible, but early planted corn has often been handicapped by the seed rotting in the ground. Semesan Jr. affords seed corn protection from rotting in cold, wet soil and at an insignificant cost of only $2 \frac{1}{2} \mathrm{c}$ an acre.

PRICES

4 oz. tin...... \$.50 1 lb. tin. . . $\$ 1.75 \quad 5$ lb. tin.... $\$ 8.00$

DUBAY SEED DISINFECTANTS are not mailable-must be sent by Express or Freight 


\section{Fertilizers}

Agricultural Lime. Lime is beneficial to all vegetable growth, unlocking the elements of fertility, and especially valuable for alfalfa. Per $80 \mathrm{lb}$. bag 80c. Special prices on large quantities.

Bone Meal. Excellent for general use or mixing with potting soil. 5 lbs. $40 \mathrm{c}, 10 \mathrm{lbs}$. $60 \mathrm{c}, 50 \mathrm{lbs} . \$ 2.00$, 100 lbs. $\$ 3.25$.

Farm Fertilizer. Can furnish local trade with any fertilizer that may be desired for particular crops. Ask for prices, stating crops for which desired.

Plant Tabbs. Odorless plant food in tablet form. Finest thing in the world for potted and outdoor plants and flowers. Can be used in tablet form or dissolved in water. $25 \mathrm{c}, 50 \mathrm{c}$, $\$ 1.00$ size boxes.

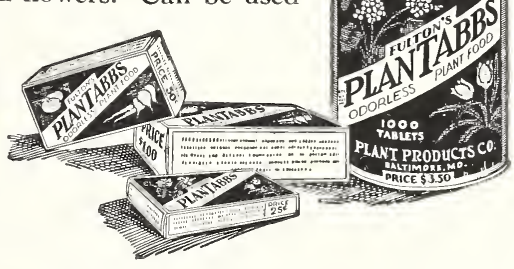

Sacco. An especially prepared plant

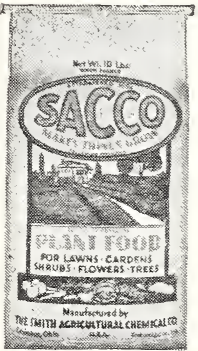
food for lawns, gardens, shrubs, flower plants, and trees. Effective and economical. A light application once or twice a year is enough to keep plants in excellent condition. Used by many florists, nurserymen and gardeners. Two to four pounds sufficient for a space $10 \times 10$. It is clean, odorless, easy to apply, and easily understood directions are printed on each package. Prices: 1 lb. can 25c, 5 lb. package $50 \mathrm{c}, 10 \mathrm{lb}$. package $85 \mathrm{c}, 25 \mathrm{lb}$. package $\$ 1.75,50 \mathrm{lb}$. bag $\$ 3.00,100 \mathrm{lb}$. bag $\$ 5.00$.

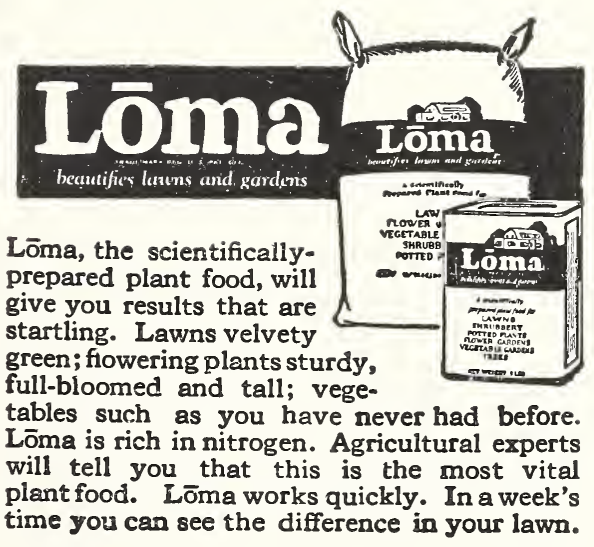

1-lb. can..................... \$ .25

5-lb. can.................... . 50

$10-1 b$. bag. .................... . 85

25-1b. bag. ................... 1.75

50 -lb. bag. ................. . 3.25

100-1b. bag. ................. 6.00

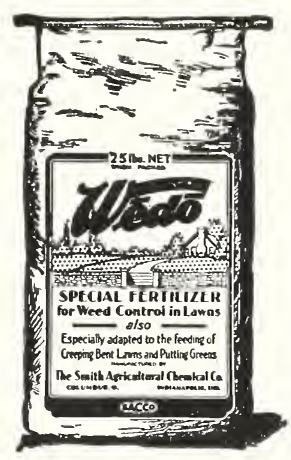

Wedo. A special fertilizer for weed control in lawns. Feeds grass-fights weeds.

Here is a dual purpose fertilizer - made as a special feeding ration for lawns only, and to control weeds.

Wedo contains the recommended amounts of Nitrogen (Ammonia), Phosphates and Potash as proven by soil authorities to be best adapted to lawn grasses.

\section{VERY ECONOMICAL}

Only $11 / 2$ pounds are required for 100 square feetabout one half the amount required when ordinary plant foods are used.

$\begin{array}{ccc}100 \mathrm{lbs} & 50 \mathrm{lbs} & 25 \mathrm{lbs} . \\ \$ 6.50 & \$ 3.75 & \$ 2.00\end{array}$

Nitrate of Soda. High in nitrogen. 1 lb. 10c, 100 lbs. $\$ 5.00$.

Sulphate of Ammonia applied to your lawn will furnish plant food (nitrogen) that promotes a vigorous grass growth, thus crowding out the weeds and at the same time it produces a soil condition that weeds do not like. 1 lb. 15c, 5 lbs. 60 c, 10 lbs. $\$ 1.00,25$ lbs. $\$ 2.25,100$ lbs. $\$ 6.00$.

Pulverized Sheep Manure. For lawns, golf greens, gardens, flowerbeds, house plants, shrubbery, etc. Our sheep manure is the best and strongest in fertilizing and enriching elements of all nature's fertilizers, containing, as it does, nitrogen, phosphoric acid, ammonia and potash in liberal proportions. It is three times stronger than cow manure. 5 lb. sack $35 \mathrm{c}, 10 \mathrm{lb}$. sack 50c, $25 \mathrm{lb}$. sack $\$ 1.00,50 \mathrm{lb}$. sack $\$ 1.50$, $100 \mathrm{lb}$. bag $\$ 2.75$.

Peat Moss. Fine, granulated, German Peat Moss. Used to improve soil. It supplies nitrogen direct to the roots of growing plants, also adds humus making soil more pliable (loose) and improves its general condition. To a marked degree, Peat Moss also contributes effective drainage and soil ventilation, when properly mixed with soil, as it absorbs and retains large amounts of moisture, so essential to plant growth. When fertilizers etc., are added, the absorbing quality of good Peat Moss increases the efficiency of same, retaining all fertilizers in solution. Peat Moss can be used for lawns, for flowers and vegetable beds. Excellent as a top dressing or mulch. Small bale (about 21/2 bu.) $\$ 1.50$.

Large bale (about 20 bu.) \$4.00.

Fertabs. One pill per plant per month. Your house plants need Fertabs, a concentrated fertilizer in pill form. Odorless, clean, no waste, unexcelled for ferns. 25c package. 


\section{Moto-Mower Power Lawn Mowers}

\section{Save Labor and Build Fine Lawns. Built in Several Sizes}

The city model for moderately sized lawns at a lower price. $21^{\prime \prime}-\$ 187.00$ F.O. B. Buffalo, N. Y.

Making or keeping a lawn beautiful, if dependent on the back-breaking job of pushing a hand mower, is far more likely to invite neglect than if the work of mowing is turned into mere play by the use of the Moto-Mower.

Frequent cutting keeps weeds from going to seed and further discourages their growth.

With little muscular effort the Moto-Mower can be run with surprising speed over the level stretches or maneuvered with ease and the utmost accuracy up, down and along steep terraces.

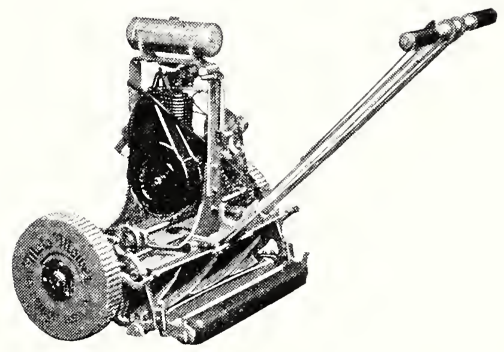

The Detroit Model

27 -inch cut $\$ 277.00$ F. O. B. Buffalo, N. Y.

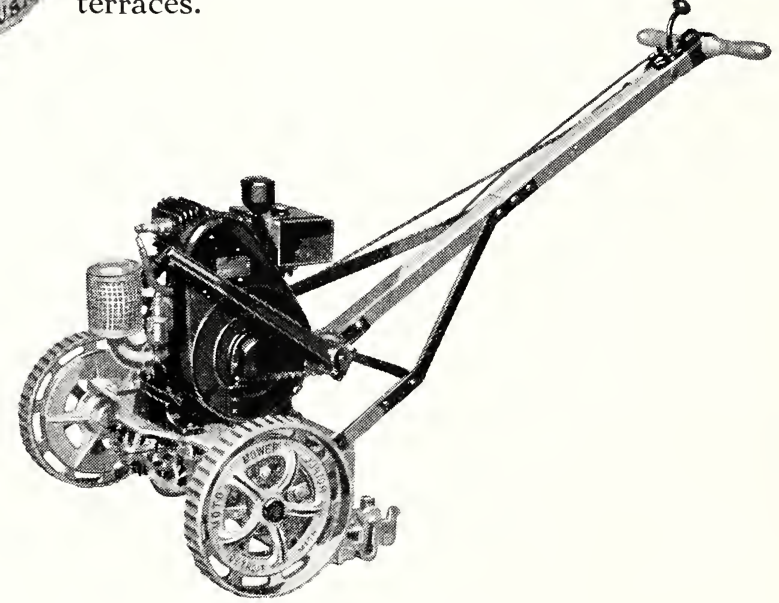

The Junior Model

A smaller, lower priced mower 18-inch cut, $\$ 140.00$ F. O. B. Buffalo, N. Y.

Ask for Demonstration

\section{Spraying Outfits}

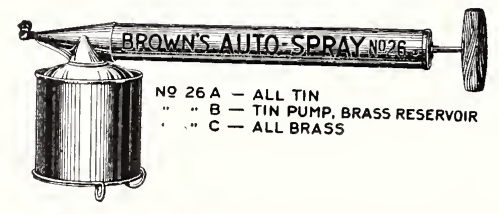

Continuous Sprayer Equipped with Double Nozzle, One for Spraying Up and One for Straight Forward No. 26C, All Brass, $\$ 1.50$
The absolute necessity of spraying, whether gardening for pleasure or farming for profit, is well understood. We have selected the best makes and types of sprayers and so can equip you to most successfully combat your particular trouble.

Compressed Air Sprayers

Brown No. 9D Galv. Cap, 4 Gals. $\$ 6.50$

Brown No. 9B Brass Cap, 4 Gals. $\$ 9.50$

Brown No. 50D, Galv. Cap, 21/2 Gals. $\$ 5.90$

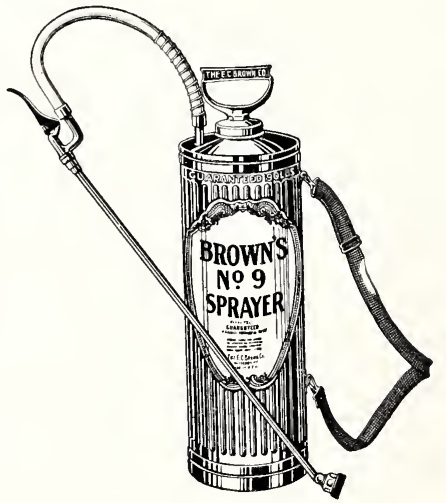

Hand Sprayers
Twin Blast Sprayers Glass Jar No. 15A

Price, 75c each

Price, $75 c$ each
Acme Tin, 1/2 Pt. Sprayers, 35c each
Acme Tin, 1 Qt. Sprayers, 50c each

Acme Galv. 1 Qt. Sprayers, 65c each 


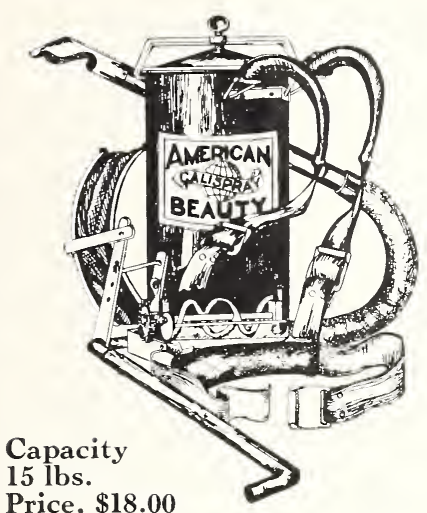

Price, $\$ 18.00$

\section{U S T E R S}

\section{Is Dusting Equal to Wet Spray?}

We quote Prof. Whetzel as follows:

"Any grower who for three years will dust with as much attention to materials applied, timeliness and thoroughness of application as he now does with wet sprays, will never use the liquid method again.

\section{Prof. H. H. Whetzell, Cornell University.}

\section{Planet Jr. Garden Tools}

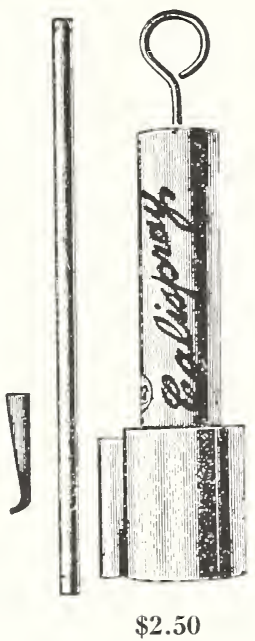

True economy consists in getting the most value for your dollar. Planet Jr. Tools are built to last, of the best materials available, and are designed to do the best work in the easiest, most efficient way. They are simple, sturdy and complete.

No. 25 Combined Hill and Drill Seeder and Double Wheel Hoe
No. 4 Combined Hill and Drill Seeder and Single Wheel Hoe

Price, $\$ 18.00$

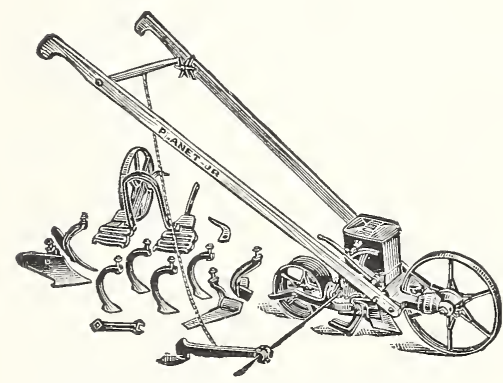

"The Complete Gardener" Price, $\$ 21.50$

No. 220 Fertilizer Distributor Price, $\$ 27.00$
No. 12 Double Wheel Hoe Includes 2 Wing Plows, 4 Cultivator Teeth, 2 Side Hoes Price, $\$ 10.75$

No. 13, Less Plows and Cultivator Teeth, Price, $\$ 8.00$

No. 300 Drill Seeder, An Accurate Plate Seeder for Market Gardeners Price, $\$ 20.00$

No. 17 Single Wheel Hoe Includes 1 Landslide Plow, 3 Cultivator Teeth, 1 Pair Side Hoes Price, $\$ 7.75$

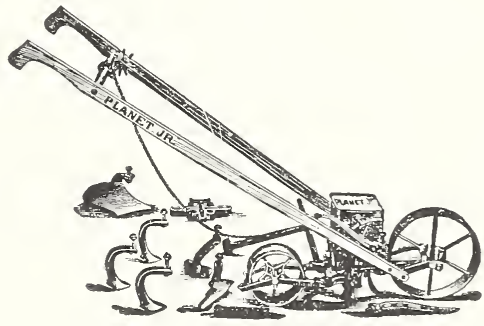

No. 4-D Seeder Only Price, $\$ 14.25$

No. 171/2, Less Plow, Price, $\$ 6.75$

No. 18, Less Plow and Cultivator Teeth, Price, $\$ 5.75$

\section{SEND FOR COMPLETE CATALOGUE}

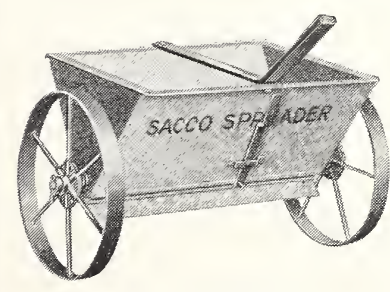

Sacco Fertilizer Distributor $\$ 20.00$

\section{TIMESAVER}

Sweet Pea, Garden Pea and Vine TRELLIS

Dimensions 5 feet by 5 feet over all.

Stands about 4 feet above ground when placed.

Frame made of $1 / 4$ inch galvanized cold drawn steel. Green non-fade rope center.

Several can be used end to end for long rows.

Price, $\$ 1.50$ each

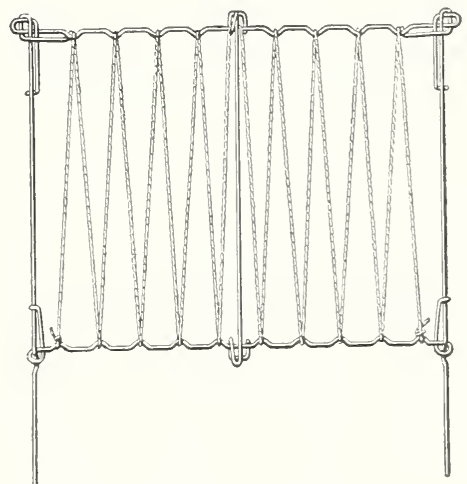




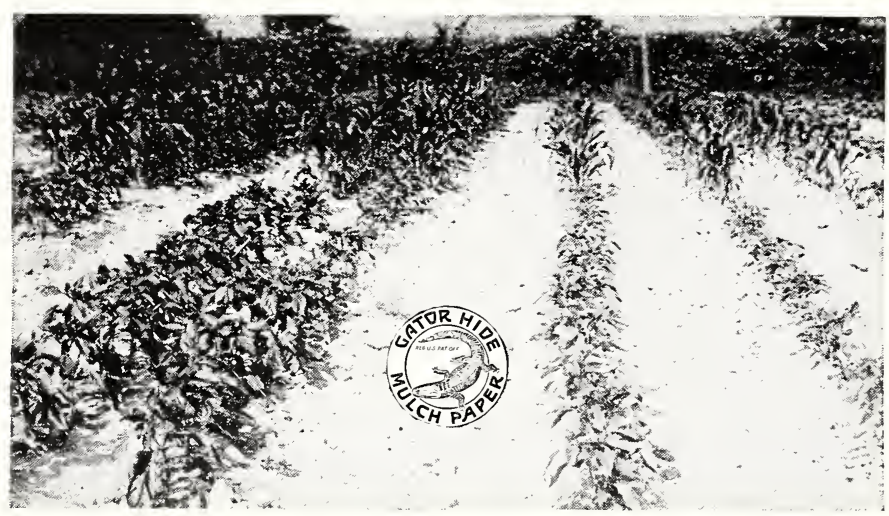

\section{Mulch Paper}

Mulch Paper conserves moisture, controls weeds, stimulates growth. Plants mature earlier and you are able to secure a larger yield. Send for booklet on the miracles of mulch paper.

18 inch roll, 900 lineal feet $\$ 3.50$

30 inch roll, 900 lineal feet $\mathbf{7 . 0 0}$

Gator-Hide Mulch Paper increases growth and yields. Compare the mulched Peppers and Corn on the left with the unmulched on the right.

\section{Paper Pots}

Black Pots. The paper has been specially treated with a water proofing saturation, followed by a water proof coating on both sides of the paper. This treatment gives the paper peculiar properties which are extremely desirable for growing young plants. These pots seem to encourage their healthy growth. Doz. 10c, 100 65c, 1000 \$5.90: $21 / 2$ inch.

\section{Ask for Price on Other Sizes}

Red Pots. This is the standard red paper pot that has been used for years. Although it has been used for growing with satisfactory results, the black pot is now recommended for that purpose and the red pot

\section{Hotcaps}

\section{New Method of Plant Protection}

Protects plants from frost and other elements, matures crops earlier, keeps insects out, keeps soil soft. They are made of a specially prepared waxed paper and are cone-like in shape, measuring about 11 inches in diameter at the base and coming to a point at the top. When placed over the plants and held firmly in place by the soil around it Hotkaps become individual miniature hothouses.

Prices: 1,000 lots, $\$ 11.50 ; 5,000$ lots, $\$ 11.00$ per $M$; 10,000 lots, $\$ 10.75$ per $M$; 250 Trial Package including Garden Setter with Tamper, \$4.00; 100 Home Package, including Garden Setter with Tamper, \$2.50; Germaco Hotkap Steel Setter with Tamper, $\$ 2.50$; postage extra. Wt.: 1,000 package HOTKAPS, 26 lbs.; 250 package, 9 lbs.; 100 package, 5 lbs.; Steel Hotkap Setter, 3 lbs.

\section{The Red Chief}

\section{Corn and Pop-Corn Sheller}

\section{Patented}

Guaranteed to do as good if not better work than any sheller on the market. Shells both Corn and Pop-Corn perfectly. Pop-corn attachment easily and quickly applied. Change made in less than one minute. Smooth oval teeth that will not crack grains. Safe to use for seed corn. Cold-rolled steel axle with $4 \frac{1}{2}$-inch bearing on hub gives machine easy and steady motion. Price $\$ 2.75$; with Pop-corn attachment $\$ 3.00$.

\section{Bird's IMERONSET Flower Pots}

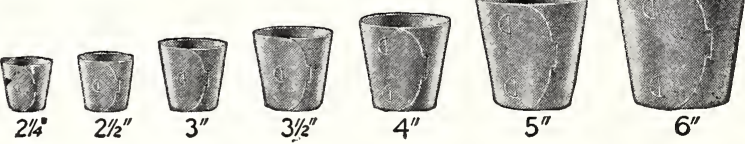

is recommended for shipping, storage, etc., as it is somewhat more economical.

Doz. 10c, 100 60c, 1000 \$5.15: 21/2 inch.

Ask for Price on Other Sizes

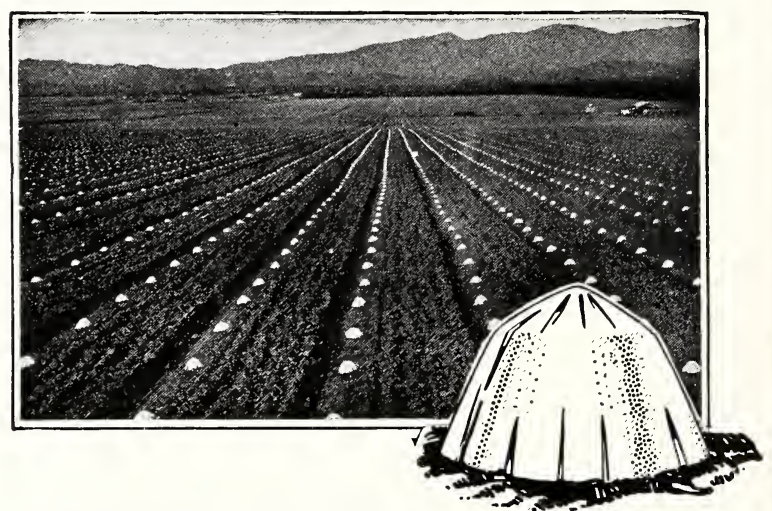

Hotkap Setter. Will prove very helpful. This is a small steel cone, the exact shape of the Hotkap itself with a handle at the top. The cost of the Hotkap setter is nominal and it can be used a lifetime.

\section{Broadcast Seed Sower}

The Best, the Cheapest, the Most Durable of all Crank Seeders

It will distribute all kinds of fertilizer, land plaster and ashes, flax and clover seed, 36 feet to the round; wheat 50 feet to the round; buckwheat 46 feet to the round; barley 40 feet to the round; timothy seed 27 feet to the round; oats 36 feet to the round.

Each

$\$ 2.25$

\section{Bee Supplies}

We are now carrying a complete line of Bee Ware which comprises practically everything for which a Beekeeper may have need. Send for catalogue. 


\title{
The Gardener's Guide and Sowing Table
}

\author{
This table has been carefully prepared and answers hundreds of \\ questions gardeners and farmers want to know. For fuller instructions \\ see cultural directions under the heading for each kind of vegetable.
}

\begin{tabular}{|c|c|c|c|c|c|c|c|c|}
\hline VARIETY & $\begin{array}{c}\text { Time to Sow } \\
\text { or } \\
\text { Plant }\end{array}$ & & & & & & $\begin{array}{c}\text { Maturity } \\
\text { of } \\
\text { Crop }\end{array}$ & \\
\hline 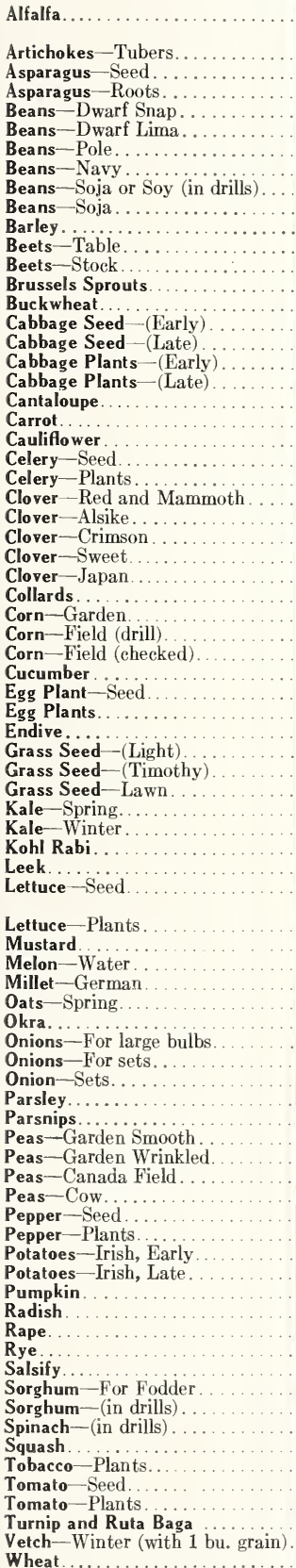 & 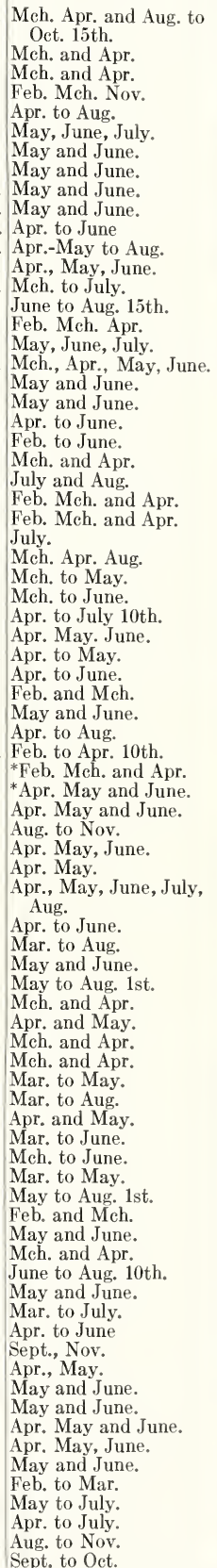 & 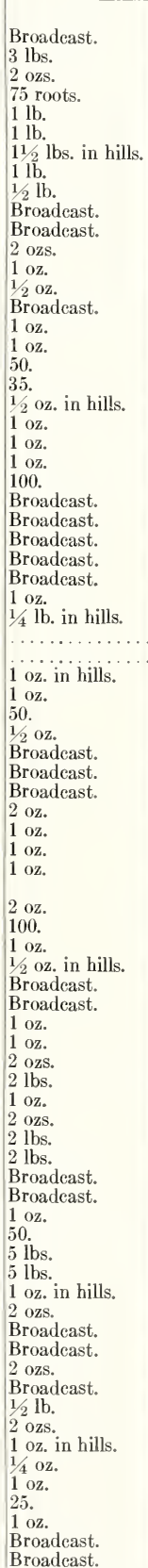 & 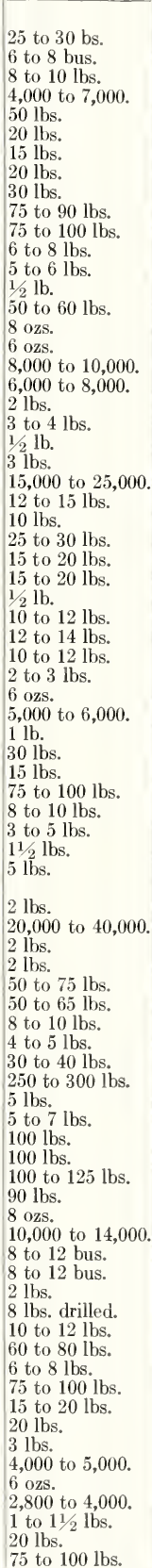 & 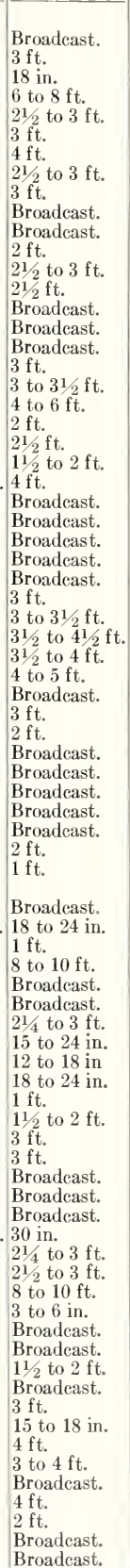 & 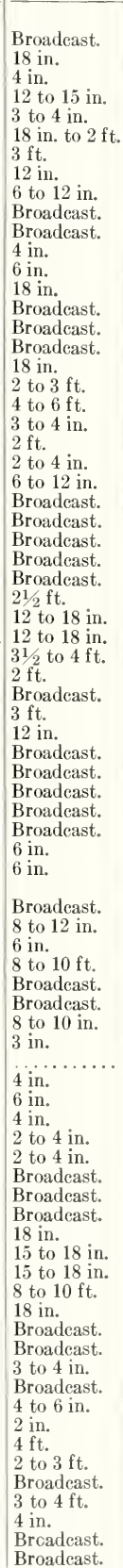 & 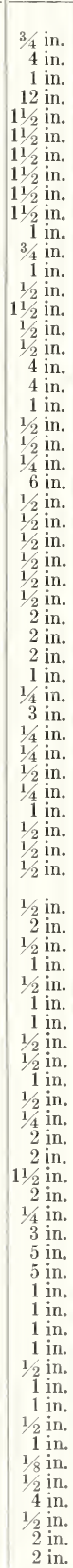 & 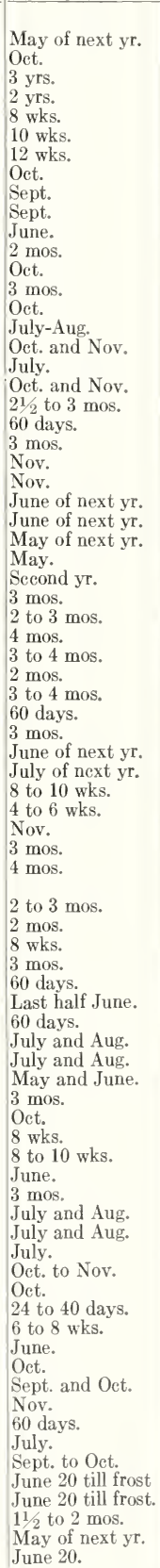 & 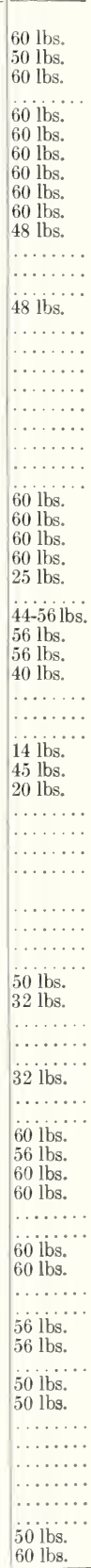 \\
\hline
\end{tabular}




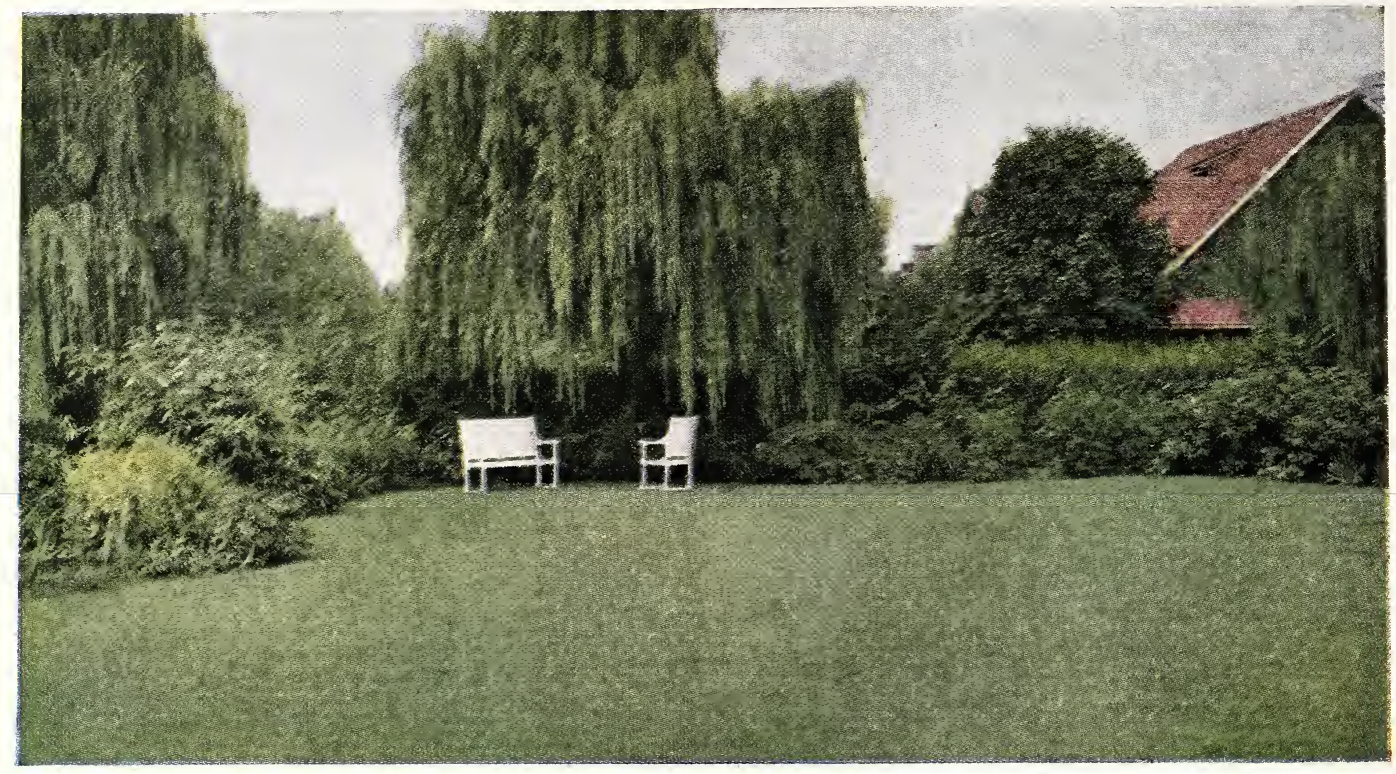

\section{Harvey's Lawn Seeds Grow Better}

\section{Preparation of the Soil}

Since the lawn is intended to be a permanent feature of the decoration of a place, its endurance or span of life is of utmost importance. In general, grass seeds are small and the surface seed bed for the reception of these seeds need not be more than one inch in depth; but since the grasses, as they become established, send out long lateral feeding roots, it is necessary that the soil area available for these plants should be as great as possible. This object can only be obtained by deep cultivation and thorough preparation of at least six or eight inches of the surface soil. In short, the land should be treated just as good farm or garden land should be treated for raising an especially valuable crop. Fertilizer should be worked into the soil according to directions of manufacturer. We recommend Sacco and Sheep Manure. After the Seed bed has been thoroughly and carefully prepared and the Grass Seed scattered in appropriate quantities, according to the kind used, the surface should be given a careful raking and a heavy lawn roller should be passed over the surface in order to make it as smooth as possible.

\section{Seed}

In procuring seed for establishing a lawn, too great care cannot be exercised. Pure seed, of high germination, is of great importance in securing a good stand of grass. Pure seed is the keynote to a clean lawn, provided the work of preparing the land has been efficiently done. Such preparation, coupled with pure seed, should give a satisfactory stand of grass which shall need only the usual care necessary to maintain a lawn after it is once established. Too much can not be said in favor of securing pure and specially selected seed. Selected seed is therefore, the most economical to buy, although the original cost is considerably more than that of the common article. The stand of grass resulting from the use of re-cleaned selected seed is much more uniform than when seed containing a great number of hulls and light seeds is employed.

\section{When to Plant a Lawn}

There is a legitimate difference of opinion in regard to the season at which it is best to plant a lawn. There are those who are very successful in lawn making who depend almost entirely upon Fall planting and there are others who are equally successful who advocate the practice of Spring planting. Both of these systems are successful and the prospective lawn maker can use the method which best suits his convenience.

\section{Harvey's Special Lawn Seed}

Is made up of an intelligently arranged combination of Fine Leaved Dwarf Grasses, which are at their best during different months of the year, thus insuring that carpet of deep velvety green so much desired by lovers of good lawns, and is as fine in quality as years of experience and careful selection of Seeds can make it. Lb. 50c, 5 lbs. $\$ 2.40,10$ lbs. $\$ 4.70,30$ lbs. $\$ 13.50$.

\section{Shady Nook Lawn Seed}

Usually it is quite difficult to obtain a satisfactory growth of grass under trees and in shady places. For such situations we recommend this mixture composed of fine dwarf growing varieties which do well in shady spots. Such situations should be watered more frequently and be fertilized at least three times during the season. Lb. 60c, 5 lbs. \$2.90, 10 lbs. $\$ 5.70,30$ lbs. $\$ 16.50$.

\section{Park Lawn Seed}

A very good lawn mixture that is less expensive than our Special mixture. Lb. 40c, 5 lbs. $\$ 1.90,10$ lbs. $\$ 3.70$. 